Daniela Stump

\title{
A PROTEÇÃO DO CLIMA MEDIANTE O TRATAMENTO DIFERENCIADO DAS ATIVIDADES ECONÔMICAS CONFORME SUAS EMISSÕES
}

\author{
Dissertação de Mestrado \\ Orientadora: Professora Doutora Livre-Docente Ana Maria de Oliveira Nusdeo
}

Faculdade de Direito da Universidade de São Paulo

São Paulo

2013 
Daniela Stump

\title{
A PROTEÇÃO DO CLIMA MEDIANTE O TRATAMENTO DIFERENCIADO DAS ATIVIDADES ECONÔMICAS CONFORME SUAS EMISSÕES
}

\author{
Dissertação de mestrado apresentada \\ ao Departamento de Direito \\ Econômico, Financeiro e Tributário, \\ sob orientação da Professora Doutora \\ Livre-Docente Ana Maria de Oliveira \\ Nusdeo.
}

Faculdade de Direito da Universidade de São Paulo

São Paulo

2013 


\section{Dedicatória}

Ao Luiz e ao Francisco, amores da minha vida. 


\section{Agradecimentos}

À minha orientadora Ana Maria de Oliveira Nusdeo por sua atenção e seu comprometimento durante a elaboração desta dissertação.

Ao Luiz por compartilhar os longos finais de semana de estudo e concentração.

Aos meus pais por todo o incentivo que recebi durante a minha vida acadêmica, sem o qual não teria chegado até aqui.

Às minhas irmãs pelos momentos de descontração ao longo da realização deste trabalho.

Finalmente, ao Francisco, que foi gestado e nasceu junto com esta dissertação, por ter me dado inspiração e força necessárias para a conclusão do mestrado. 


\section{Resumo}

A presente dissertação de mestrado reflete o resultado da pesquisa realizada para testar a hipótese de que a alocação do ônus das ações para mitigação das mudanças climáticas entre as atividades econômicas deve considerar as respectivas emissões para efetivar os ditames constitucionais e os dispositivos da Lei Federal n ${ }^{\circ}$ 12.187, de 29 de dezembro de 2009 (Política Nacional sobre Mudança do Clima). Confirmada a hipótese de pesquisa, esta dissertação apresenta os critérios para alocação de metas diferenciadas de redução de emissões de Gases de Efeito Estufa entre setores e fontes emissoras individuais, revelados pela doutrina e aplicados nas experiências internacionais de cap-and-trade. Por fim, verifica se os Planos Setoriais de Mitigação e de Adaptação às Mudanças Climáticas, publicados em suas versões preliminares e finais, adotam os critérios identificados pela pesquisa.

Palavras-chave: Política Nacional sobre Mudança do Clima - Tratamento diferenciado das atividades econômicas - Planos Setoriais de Mitigação e de Adaptação às Mudanças Climáticas 


\begin{abstract}
This essay presents the outcome of a research that sought to put in test the hypothesis that the allocation of the burden of climate change mitigation actions among business sectors shall take into consideration the respective associated emissions in order to comply with the Federal Constitution and the Federal Law N. 12, 187 passed on December 29, 2009 (National Policy on Climate Change). Once the hypothesis is confirmed, this essay presents the criteria for allocating differentiated Greenhouse Gases emissions reduction targets among business sectors and individual emissions sources, as they are revealed by the doctrine and applied by international experiences on cap-and-trade mechanisms. Finally, this essay verifies whether the Sectorial Plans on Climate Change Mitigation and Adaptation, as published in their preliminary and definitive versions, adopt the criteria identified in the research.
\end{abstract}

Key words: National Policy on Climate Change - Differentiated treatment of business sectors - Sectorial Plans on Climate Change Mitigation and Adaptation 


\section{SUMÁRIO}

GLOSSÁRIO

INTRODUÇ̃̃ O

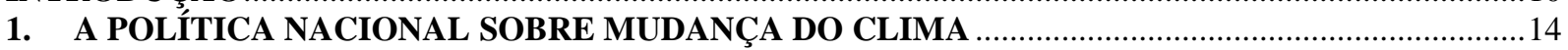

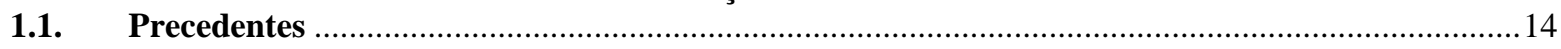

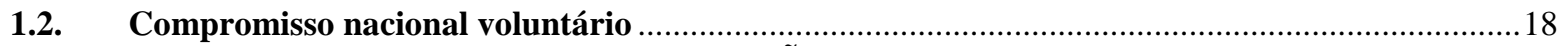

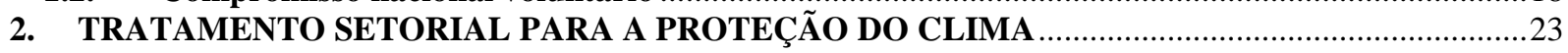

2.1. Planos setoriais de mitigação e de adaptação às mudanças climáticas ............................................23

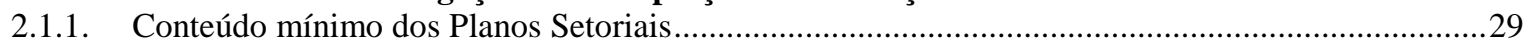

2.2. Fundamento constitucional do tratamento setorial para proteção do clima .....................................35

3. CRITÉRIOS PARA ALOCAÇÃO DIFERENCIADA DE METAS DE REDUÇÃO POR SETOR E

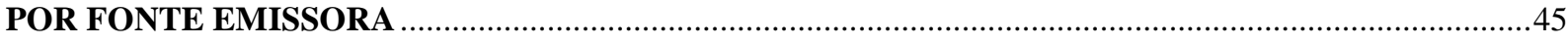

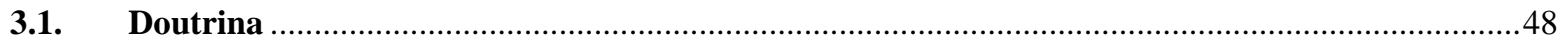

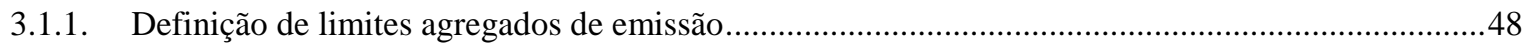

3.1.2. Individualização dos limites de emissões entre as fontes emissoras ................................................61

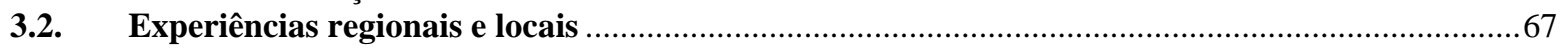

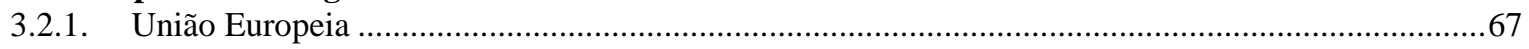

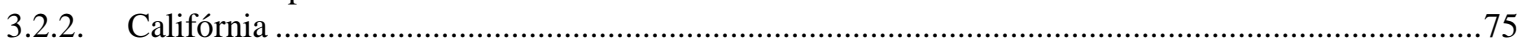

3.3. Sistematização do ferramental doutrinário e empírico …………………………........................79

4. IDENTIFICAÇÃO DOS CRITÉRIOS ANALISADOS NOS PLANOS SETORIAIS ............................ 81

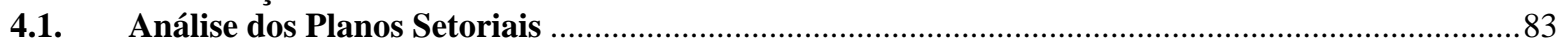

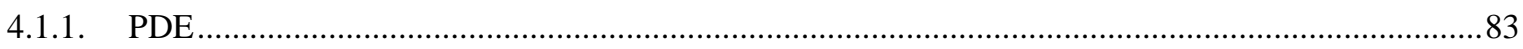

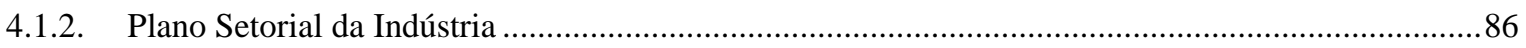

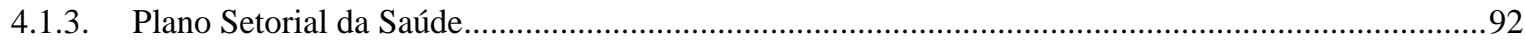

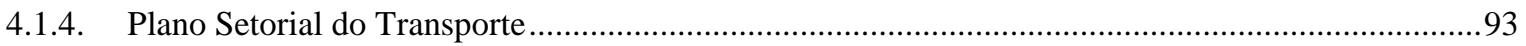

4.1.5. Plano Setorial da Mineração ..............................................................................................

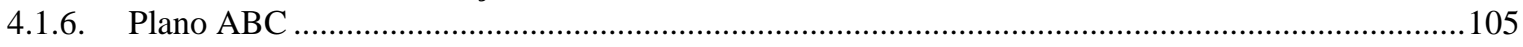

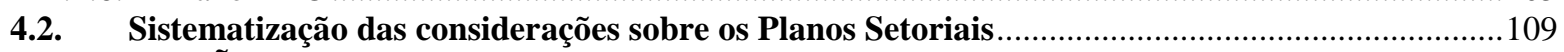

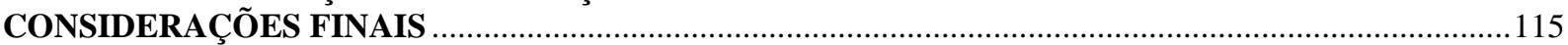

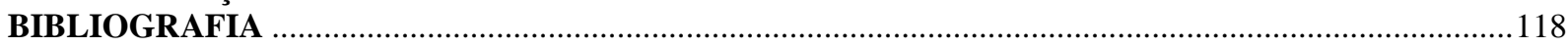




\section{GLOSSÁRIO}

ARB

CA-ETS

Convenção do Clima

COP

CIM

CIMGC

$\mathrm{CNI}$

$\mathrm{CO}_{2} \mathrm{eq}$

CONAMA

EU-ETS

GEE

IPCC

MBRE

MDL

NAMA

PDE

Plano ABC
State Air Resources Board

ARB Emissions Trading Program

Convenção-Quadro das Nações Unidas sobre Mudança do Clima

Conferência das Partes da Convenção-Quadro das Nações Unidas sobre Mudança do Clima

Comitê Interministerial sobre Mudança do Clima

Comissão Interministerial de Mudança Global do Clima

Confederação Nacional da Indústria

Dióxido de Carbono Equivalente

Conselho Nacional do Meio Ambiente

Sistema Europeu de Comércio de Emissões

Gases de Efeito Estufa

Painel Intergovernamental de Mudança do Clima

Mercado Brasileiro de Reduções de Emissões

Mecanismo de Desenvolvimento Limpo

Ações de Mitigação Nacionalmente Apropriadas

Plano Decenal de Expansão de Energia

Plano para a Consolidação de uma Economia de Baixa

Emissão de Carbono na Agricultura

Planos de Prevenção ao Desmatamento Planos de Prevenção e Controle de Desmatamento nos Biomas

PNLT

PNMA

PNMC
Plano Nacional de Logística e Transportes

Política Nacional do Meio Ambiente (Lei Federal $\mathrm{n}^{\circ}$ $6.938 / 81)$

Política Nacional sobre Mudança do Clima (Lei Federal $\mathrm{n}^{\circ} 7.390 / 10$ ) 
PPCerrado

PPCDAm

Planos Setoriais

Plano Setorial da Indústria

Plano Setorial da Mineração

Plano Setorial do Transporte

Plano Setorial da Saúde

$\mathrm{RCE}$

Segundo Inventário Brasileiro
Plano de Ação para a Prevenção e Controle do Desmatamento e das Queimadas no Cerrado

Plano de Ação para a Prevenção e Controle do Desmatamento na Amazônia Legal

Planos Setoriais de Mitigação e de Adaptação às Mudanças Climáticas

Plano Setorial de Mitigação da Mudança Climática para a Consolidação de uma Economia de Baixa Emissão de Carbono na Indústria de Transformação

Plano de Mineração de Baixa Emissão de Carbono

Plano Setorial de Transporte e de Mobilidade Urbana para Mitigação da Mudança do Clima

Plano Setorial da Saúde para Mitigação e Adaptação à Mudança do Clima

Reduções Certificadas de Emissões

Segundo Inventário Brasileiro de Emissões e Remoções Antrópicas de Gases de Efeito Estufa não Controlados pelo Protocolo de Montreal 


\section{INTRODUÇÃO}

A hipótese inicial da presente pesquisa pode ser formulada da seguinte forma: a alocação do ônus das ações de prevenção e mitigação das mudanças climáticas entre as atividades econômicas deve considerar as respectivas emissões para efetivar os ditames constitucionais e os dispositivos da Lei Federal $n^{\circ}$ 12.187, de 29 de dezembro de 2009, que instituiu a Política Nacional sobre Mudança do Clima ("PNMC").

Nesse sentido, a questão de partida é se a quantidade de emissões de Gases de Efeito Estufa (GEE) liberada por cada atividade econômica deva ser ponderada para a determinação da obrigação de redução de emissões de cada qual.

A hipótese de pesquisa inicial será confirmada por meio da análise da PNMC e das normas constitucionais que regem a proteção do meio ambiente e a ordem econômica. A pesquisa revelou que a PNMC impõe a consideração da contribuição de cada fonte emissora para os efeitos ocasionados sobre o clima para a adoção de medidas para prevenção e mitigação do fenômeno global.

O disposto na PNMC está inteiramente amparado na Constituição Federal, em seu artigo 170, inciso VI, que autoriza o tratamento diferenciado das atividades econômicas para a defesa do meio ambiente, de acordo com o impacto ambiental dos produtos e serviços e de seus processos de elaboração e prestação.Com base no resultado da pesquisa orientada pela hipótese inicial, a presente dissertação propõe sintetizar a forma com que a PNMC e a Constituição Federal determinam a alocação do ônus das ações de prevenção e mitigação da mudança do clima entre as atividades econômicas pela expressão proteção do clima mediante o tratamento diferenciado das atividades econômicas ${ }^{l}$ conforme suas emissões.

Com fundamento na confirmação da hipótese de pesquisa inicial, esta dissertação busca responder a uma segunda questão sobre os critérios revelados pela doutrina e pelas experiências internacionais que podem servir para a efetivação das diretrizes da Constituição Federal e da PNMC. Identificados esses critérios, o objetivo é verificar se os Planos Setoriais

\footnotetext{
${ }^{1}$ Empregamos aqui a expressão atividades econômicas em seu sentido amplo, incluindo aquelas desenvolvidas pelo Estado, no campo dos serviços públicos (GRAU, 2002, p. 146). Os termos setores econômicos e atividades econômicas serão empregados indistintamente.
} 
de Mitigação e de Adaptação às Mudanças Climáticas ("Planos Setoriais”), publicados em suas versões preliminares e finais até a conclusão desta dissertação, os adotam.

A metodologia utilizada para abordar critérios de diferenciação das atividades econômicas para a fixação de limite agregado de emissões e alocação de metas de redução de emissões entre as fontes individuais, de acordo com as suas respectivas responsabilidades quanto à origem das emissões e os efeitos ocasionados ao clima, consiste no estudo dos mecanismos de mercado de emissões já implantados na União Europeia e em fase de implantação na Califórnia para

Com isso, reuniremos as ferramentas doutrinárias e empíricas necessárias para estudar os Planos Setoriais publicados até o momento da conclusão desta dissertação, com o foco na efetivação dos dispositivos normativos da Constituição Federal e da PNMC.

Para confirmar ou contestar a hipótese inicial e responder às questões formuladas ao longo da pesquisa, acima apresentadas, a dissertação parte da apresentação da PNMC, regulamentada pelo Decreto Federal n ${ }^{\circ} 7.390$, de 09 de dezembro de 2010. O primeiro capítulo abordará o contexto internacional em que foi concebida a PNMC, o que foi determinante para o estabelecimento de compromisso nacional voluntário para a adoção de ações de mitigação das emissões de Gases de Efeito Estufa (“GEE”) com o fim de desviar de 36,1\% a 38,9\%² a curva de emissões brasileiras projetadas até 2020.

O segundo capítulo tratará da abordagem setorial proposta pela PNMC para cumprimento do compromisso nacional voluntário. Serão analisados os contornos dentro dos quais os Planos Setoriais devem ser publicados pelo Poder Público para as atividades de geração e distribuição de energia elétrica; transporte público urbano e sistemas modais de transporte interestadual de cargas e passageiros; indústria de transformação e de bens de consumo duráveis; indústrias químicas fina e de base; indústria de papel e celulose; mineração; indústria da construção civil; serviços de saúde; e agropecuária.

O segundo capítulo ainda trará a fundamentação constitucional e legal do tratamento setorial para a proteção do clima. A PNMC impõe ao Poder Público a alocação do ônus da redução de emissões de GEE entre os setores econômicos, considerando-se as 
"responsabilidades individuais quanto à origem das fontes emissoras e dos efeitos ocasionados sobre o clima"3. Objetiva também demonstrar que a interferência do Poder Público na forma como o setor privado desenvolve a atividade econômica encontra amparo específico no artigo 225, $\$ 1^{\circ}$, inciso I, da Constituição Federal, que autoriza o controle da produção, da comercialização e do emprego de técnicas, métodos e substâncias "que comportem risco para a vida, a qualidade de vida e o meio ambiente". O segundo capítulo ainda revelará que a defesa do meio ambiente por meio da intervenção estatal na economia deve respeitar limites previstos na própria lei maior.

Por fim, o segundo capítulo se encerrará com a construção da ideia de que a Constituição Federal autoriza que o estabelecimento de metas setoriais considere "responsabilidades individuais quanto à origem das fontes emissoras e dos efeitos ocasionados sobre o clima” para a alocação de metas de redução de GEE. As considerações expostas no segundo capítulo fundamentam a ideia da proteção do clima mediante o tratamento diferenciado das atividades econômicas ${ }^{4}$ conforme suas emissões.

A partir da orientação conferida pela PNMC e pela Constituição Federal quanto ao tratamento setorial das ações de mitigação da mudança do clima e diferenciação das atividades econômicas conforme suas emissões, o terceiro capítulo pretende investigar quais são os critérios propostos pela doutrina e aplicados pelas experiências internacionais para alocação do ônus da redução de emissões entre os setores e fontes individuais de emissões ${ }^{5}$.

Serão analisados no terceiro capítulo os mecanismos de mercado de emissões já implantados na União Europeia e em fase de implantação na Califórnia para a fixação de limite agregado de emissões e alocação de metas de redução de emissões entre as atividades

\footnotetext{
${ }^{2}$ Artigo 12 da PNMC.

${ }^{3}$ Segundo o disposto no artigo $3^{\circ}$, inciso III, as medidas tomadas para prever, evitar ou minimizar as causas identificadas da mudança do clima "devem levar em consideração os diferentes contextos socioeconômicos de sua aplicação, distribuir os ônus e encargos decorrentes entre os setores econômicos e as populações e comunidades interessadas de modo equitativo e equilibrado e sopesar as responsabilidades individuais quanto à origem das fontes emissoras e dos efeitos ocasionados sobre o clima". (grifos nossos)

5 Adotaremos o conceito de fonte emissora empregado na Resolução $n^{\circ} 382$, aprovada pelo Conselho Nacional de Meio Ambiente ("CONAMA"), em 26 de dezembro de 2006, para a qual fonte fixa de emissão é "qualquer instalação, equipamento ou processo, situado em local fixo, que libere ou emita matéria para a atmosfera, por emissão pontual ou fugitiva".
} 
econômicas de acordo com as suas respectivas responsabilidades quanto à origem das emissões e os efeitos ocasionados ao clima.

Reunido o ferramental doutrinário e empírico necessário para efetivar as diretrizes da PNMC e da Constituição Federal no que tange à proteção do clima mediante o tratamento diferenciado das atividades econômicas conforme suas emissões, o quarto capítulo analisa os Planos Setoriais publicados até a finalização desta dissertação, em suas versões preliminares e finais: (i) Plano Decenal de Expansão de Energia ("PDE”); (ii) Plano Setorial de Mitigação da Mudança Climática para a Consolidação de uma Economia de Baixa Emissão de Carbono na Indústria de Transformação ("Plano Setorial da Indústria”); (iii) Plano de Mineração de Baixa Emissão de Carbono ("Plano Setorial da Mineração"); (iv) Plano Setorial de Transporte e de Mobilidade Urbana para Mitigação da Mudança do Clima ("Plano Setorial do Transporte”); (v) Plano Setorial da Saúde para Mitigação e Adaptação à Mudança do Clima ("Plano Setorial da Saúde”) e (vi) Plano para a Consolidação de uma Economia de Baixa Emissão de Carbono na Agricultura ("Plano ABC”).

Ao longo da análise dos Planos Setoriais, serão feitas considerações acerca do reflexo dos conceitos pinçados na doutrina e nas experiências internacionais no estabelecimento de ações de mitigação e metas de redução para cada atividade econômica abarcada pelos planos. Tais considerações serão sistematizadas ao final do capítulo 4, concluindo-se que alguns dos Planos Setoriais adotam os critérios apontados no capítulo 3 para a efetivação da proteção do clima mediante o tratamento diferenciado das atividades econômicas conforme suas emissões.

A presente dissertação é finalizada com a demonstração da confirmação da hipótese de pesquisa e com as respostas às questões inicialmente propostas. 


\section{A POLÍTICA NACIONAL SOBRE MUDANÇA DO CLIMA}

\subsection{Precedentes}

A evolução do quadro normativo brasileiro aplicável às emissões de GEE é cadenciada pelas negociações internacionais voltadas à construção de um regime global de proteção do clima.

Adotamos como marco inicial a promulgação da Convenção do Clima, por meio da publicação do Decreto Federal n² 2.652, de $1^{\circ}$ de julho de 1998.

Para compreender os interesses envolvidos nas negociações da Convenção do Clima, com importantes reflexos no texto aprovado e na aplicação de suas disposições, é importante analisar a configuração das forças políticas que estiveram presentes à época, nas palavras do diplomata André Aranha Corrêa do Lago:

Várias questões, como as incertezas científicas, tornaram o processo negociador particularmente complicado, mas o custo das medidas que permitiriam desacelerar o processo de aquecimento global foi o fator que maiores dificuldades provocou, dividindo as delegações em basicamente três grupos: 1) os países em desenvolvimento, que esperavam recursos financeiros novos e adicionais e a transferência de tecnologia para tomar as medidas que exigem maiores recursos; 2) os países ricos, representados principalmente pelos membros da Comunidade Europeia, que já haviam progredido na diminuição de emissões, e cujos gastos para atingir as primeiras metas sugeridas pareciam viáveis; e 3) outros países ricos, como os Estados Unidos - apoiados pelos países produtores de petróleo - que não viam como possível atingir as metas sugeridas sem sacrifícios econômicos excessivos. A solução encontrada foi a de diluir o texto e não mencionar metas específicas, mas houve, pelo menos, consenso quanto à necessidade de redução das emissões de gases de efeito estufa. (CORRÊA DO LAGO, 2005, p. 51) 
A confluência de interesses nacionais em cena implicou adoção de tratado que indica diretrizes gerais para alcançar o objetivo de estabilizar as concentrações de GEE na atmosfera, em nível seguro para o sistema climático.

A obrigação de reduzir GEE recaiu apenas sobre os países listados no Anexo I da Convenção do Clima, que se comprometeram a voltar aos níveis de emissão de 1990, de forma individual ou conjunta ${ }^{6}$. Como Parte da Convenção do Clima, na condição de país em desenvolvimento e não listado em seu Anexo I ${ }^{7}$, o Brasil comprometeu-se a empreender esforços voluntários para atingir o objetivo da Convenção.

Entre os compromissos aos quais o País aderiu com a assinatura e a ratificação da Convenção do Clima estão o de publicar periodicamente inventário nacional de suas emissões, por meio da Comunicação Nacional à Convenção do Clima, e o de implementar programas nacionais que incluam medidas de mitigação da mudança do clima ${ }^{8}$.

O Protocolo de Quioto, assinado pelo Brasil em 1997 e promulgado pelo Decreto Federal $\mathrm{n}^{\circ} 5.445$, de 12 de maio de 2005, permitiu que as emissões voluntariamente evitadas nos países não listados no Anexo I fossem utilizadas pelos países do Anexo I para cumprimento de suas metas de redução (correspondentes, em média, à redução de 5\% das emissões havidas em 1990).

A participação brasileira no Mecanismo de Desenvolvimento Limpo ("MDL") foi viabilizada pela construção de arcabouço institucional e normativo cuja coordenação compete à Comissão Interministerial de Mudança Global do Clima ("CIMGC")". As resoluções normativas expedidas pela CIMGC internalizaram os procedimentos para aprovação de projetos de MDL no País e garantiram segurança jurídica para a realização de investimentos estrangeiros visando à redução de emissões de GEE no território brasileiro, dos quais entidades públicas e privadas passaram a se beneficiar.

\footnotetext{
${ }^{6}$ Artigo $2^{\circ}$, alínea b, da Convenção-Quadro das Nações Unidas sobre Mudança do Clima.

${ }^{7}$ Reservado aos países-membros da OCDE e países em transição para uma economia de mercado.

${ }^{8}$ Artigo 4º alíneas "a" e "b", da Convenção-Quadro das Nações Unidas sobre Mudança do Clima.

${ }^{9}$ Instituída pelo Decreto de 07 de julho de 1999, composta por Ministério das Relações Exteriores, Ministério da Fazenda, Ministério da Agricultura, Pecuária e Abastecimento, Ministério dos Transportes, Ministério de Minas e Energia, Ministério do Planejamento, Orçamento e Gestão, Ministério do Meio Ambiente, Ministério da Ciência e Tecnologia, Ministério do Desenvolvimento, Indústria e Comércio Exterior, Ministério das Cidades e Casa Civil da Presidência da República.
} 
A possibilidade de alienação das Reduções Certificadas de Emissões ("RCE”) geradas por atividades de projetos de MDL sediadas no País estimulou empresas a mudarem o curso natural de seus negócios e a adotarem ações para redução ou remoção das suas emissões projetadas.

Em 2007, ano da realização da $13^{\mathrm{a}}$ Conferência das Partes da Convenção do Clima (“COP-13”), os países comprometeram-se a encetar negociações para a adoção de ações adicionais voltadas ao alcance do objetivo da Convenção do Clima. O Plano de Ação de Bali $^{10}$, aprovado pelas Partes da Convenção ao final da COP-13, formalizou o compromisso de intensificação das medidas nacionais e internacionais de mitigação da mudança do clima, levando-se em consideração:

Compromissos ou medidas de mitigação adequados a cada país que possam ser mensurados, relatados e verificados, entre os quais os objetivos quantificados de limitação e redução de emissões, de todas as Partes países desenvolvidos, assegurando-se a comparabilidade dos esforços entre elas e levando-se em conta as diferenças de suas circunstâncias nacionais. (grifos nossos)

E, adicionalmente,

[M]edidas de mitigação adequadas a cada país para as Partes países em desenvolvimento, no contexto do desenvolvimento sustentável, com o apoio tecnológico, financeiro e de capacitação adequados, de maneira que possam ser mensurados, relatados e verificados. (grifos nossos)

As medidas de mitigação previstas para os países em desenvolvimento foram denominadas "NAMA"s, a partir da expressão em inglês Nationally Appropriate Mitigation Actions, traduzida para o português como Ações de Mitigação Nacionalmente Apropriadas.

\footnotetext{
${ }^{10}$ Decisão 1/CP.13.
} 
Sob a influência do Plano de Ação de Bali, o governo brasileiro elaborou o Plano Nacional sobre Mudança do Clima, coordenado pelo Comitê Interministerial sobre Mudança do Clima ("CIM") ${ }^{11}$ e apresentado à comunidade internacional durante a $14^{\text {a }}$ Conferência das Partes da Convenção sobre Mudança do Clima (“COP-14”), em dezembro de 2008. O plano objetiva identificar e articular as ações de mitigação de emissões de GEE no território brasileiro, assim como propor medidas voltadas à adaptação da população aos efeitos do fenômeno climático.

O Plano Nacional sobre Mudança do Clima entende por mitigação a "implementação de medidas que reduzam as fontes de emissão de gases de efeito estufa e aumentem os sumidouros de carbono" (BRASIL, 2008). Adaptação é tida como "iniciativas e medidas para reduzir a vulnerabilidade dos sistemas naturais e humanos frente aos efeitos atuais e esperados da mudança do clima" (BRASIL, 2009b).

O Plano Nacional sobre Mudança do Clima aborda diversos setores da economia brasileira, traçando diretrizes gerais para a contribuição de cada qual para a redução de emissões $^{12}$. É na área do desmatamento que o plano traça os objetivos mais audaciosos. O País comprometeu-se unilateralmente a reduzir o desmatamento da Amazônia em $40 \%$ (quarenta por cento) no período 2006-2009, em relação à média do período compreendido entre 19962005, e em 30\% (trinta por cento) adicionais em cada um dos dois quadriênios seguintes, relativamente aos quadriênios anteriores ${ }^{13}$.

Impulsionado pela pressão da opinião pública internacional, incitada pela promessa de conclusão das negociações do Plano de Ação de Bali na $15^{\mathrm{a}}$ Conferência das Partes da Convenção sobre Mudança do Clima (“COP-15”), tanto quanto pela corrida presidencial que levou os principais candidatos a Copenhague (ABRANCHES, 2010, p. 178-183), o Congresso Nacional brasileiro aprovou a Lei Federal $n^{\circ} 12.187$, de 29 de dezembro de 2009, que instituiu a PNMC.

\footnotetext{
${ }^{11}$ Instituído pelo Decreto ${ }^{\circ}$ 6.263, de 21 de novembro de 2007, que também orienta a elaboração do Plano Nacional sobre Mudança do Clima.

${ }^{12}$ O Plano Nacional sobre Mudança do Clima é baseado nos dados do Primeiro Inventário Brasileiro de Emissões e Remoções Antrópicas de Gases de Efeito Estufa não Controlados pelo Protocolo de Montreal.

${ }^{13}$ Com a instituição da Política Nacional de Mudança do Clima, em 29 de dezembro de 2009, o Plano Nacional sobre Mudança do Clima passa a ser incorporado como um dos instrumentos de efetivação da política.
} 
As negociações sob a égide do Plano de Ação de Bali não foram concluídas na COP15, tampouco na $16^{\mathrm{a}}$ Conferência das Partes da Convenção sobre Mudança do Clima ("COP16”), realizada no ano seguinte na cidade de Cancun. Contudo, o Brasil, por meio da instituição da PNMC, cumpriu seu compromisso internacional de adotar medidas de mitigação adequadas de forma que possam ser mensuradas, relatadas e verificadas.

Em síntese, são objetivos da PNMC: (i) compatibilizar o desenvolvimento econômicosocial com a proteção do sistema climático; (ii) reduzir as emissões antrópicas de GEE por suas diversas fontes; (iii) fortalecer as remoções por sumidouros de GEE no território nacional; (iv) promover a adaptação à mudança do clima; (v) preservar, conservar e recuperar os recursos ambientais; (vi) consolidar e expandir as áreas legalmente protegidas e incentivar reflorestamentos e a recomposição da cobertura vegetal; e (vii) estimular o desenvolvimento do Mercado Brasileiro de Redução de Emissões ("MBRE”)"14.

\subsection{Compromisso nacional voluntário}

Influenciada pelo contexto internacional em que foi concebida, a PNMC prevê que o País

adotará, como compromisso nacional voluntário, ações de mitigação das emissões de gases de efeito estufa, com vistas em reduzir entre $36,1 \%$ (trinta e seis inteiros e um décimo por cento) a 38,9\% (trinta e oito inteiros e nove décimos por cento) suas emissões projetadas até $2020^{15}$.

Nos termos dispostos no parágrafo único do artigo 12 da PNMC, a projeção das emissões para 2020 e o detalhamento das ações para alcançar o objetivo de redução de emissões devem ser regulamentados por decreto, com base no Segundo Inventário Brasileiro de Emissões e Remoções Antrópicas de Gases de Efeito Estufa não Controlados pelo Protocolo de Montreal (“Segundo Inventário Brasileiro”), que seria concluído em 2010.

\footnotetext{
${ }^{14}$ Artigo $4^{\circ}$ da PNMC.

${ }^{15}$ Artigo 12 da PNMC.
} 
A expressa menção da PNMC ao caráter voluntário do compromisso nacional de redução de GEE visa compatibilizar as ações de mitigação a serem adotadas no território brasileiro com o regime jurídico internacional de proteção do clima. Nesse sentido, o Estado Brasileiro afirma que as ações domésticas buscam contribuir com o objetivo da Convenção do Clima, mas não constituem obrigações internacionais de redução de emissões e, portanto, podem ser alcançadas por meio de atividades de projeto de MDL ou pela adoção de NAMAs, que pressupõem ações de natureza voluntária, embora possam ser mensuradas, relatadas e verificadas ${ }^{16}$.

Contudo, afirmar a voluntariedade das ações promovidas pelo Estado Brasileiro não implica necessariamente afirmar que não serão impostas aos administrados obrigações de redução de emissões de GEE para que o País atinja o objetivo fixado.

Com relação ao detalhamento desse compromisso de redução, no último trimestre de 2010 foi divulgado o Segundo Inventário Brasileiro, como parte da Segunda Comunicação Nacional à Convenção-Quadro das Nações Unidas sobre Mudança do Clima, cuja elaboração foi coordenada pelo Ministério da Ciência e Tecnologia (BRASIL, 2010).

O Segundo Inventário Brasileiro atende às diretrizes da Decisão 17/CP.8, adotada na $8^{\mathrm{a}}$ Conferência das Partes da Convenção do Clima ("COP-8"), e apresenta como ano-base o de 2000. Traz como informação adicional a evolução das emissões a partir de 1994, ano-base do Primeiro Inventário Brasileiro, até o ano 2005. O Segundo Inventário Brasileiro aplica as metodologias para realização de inventários nacionais publicadas pelo Painel Intergovernamental de Mudança do Clima ("IPCC") e contempla os seguintes setores: Energia; Processos Industriais; Uso de Solventes e outros Produtos; Agropecuária; Mudança do Uso da Terra e Florestas; e Tratamento de Resíduos (BrasIL, 2010, p. 134).

\footnotetext{
${ }^{16}$ Ana Maria de Oliveira Nusdeo, ao tratar dos requisitos do MDL, afirma que a questão da adicionalidade das reduções de emissões promovidas por uma atividade de projeto passa pela questão acerca da existência de legislação que obrigue tais reduções no país hospedeiro. Sinaliza que a resposta a essa questão deve levar em consideração a "endêmica falta de recursos existentes nos países em desenvolvimento para tornar efetivas normas avançadas de proteção ambiental que implicam investimentos em tecnologias muitas vezes inviáveis para as pessoas físicas e jurídicas destinatárias das normas em questão”. (NUSDEO, 2005)
} 
Conforme as estimativas divulgadas no Segundo Inventário Brasileiro, somando-se as emissões líquidas de $\mathrm{GEE}^{17}$ de todos os setores, tivemos, no ano de 2005, liberação de “1.637.905 Gg CO2; 18.107 Gg CH4; 546 Gg N2O; 0,124 Gg CF4, 0,0104 Gg C2F6, 0,0252 Gg SF6, 2,28 Gg HFC-134a, 0,125 Gg HFC-125, 0,093 Gg HFC-143a e 0,175 Gg HFC-152a" (BRASIL, 2010a, p. 140). Ademais,

Entre 1990 e 2005, as emissões totais de CO2, CH4 e N2O aumentaram em $65 \%, 37 \%$ e $45 \%$, respectivamente. As emissões de gases de efeito estufa indireto foram também avaliadas. No ano de 2005, essas emissões foram estimadas em 3.399 Gg NOx; 41.339 Gg CO; e 2.152 Gg NMVOC. (BRASIL, 2010a, p. 140)

Com base nos dados do Segundo Inventário Brasileiro e de outros estudos setoriais oficiais $^{18}$, o Decreto Federal n ${ }^{\circ} 7.390 / 2010^{19}$ publicou a projeção de emissões brasileiras para o ano de $2020^{20}$, equivalentes a 3.236 milhões de toneladas de $\mathrm{CO}_{2} \mathrm{eq}^{21}$.

A projeção global é composta pelas seguintes projeções setoriais:

(i) Mudança de uso da terra: 1.404 milhões de toneladas de $\mathrm{CO}_{2} \mathrm{eq}$;

(ii) Energia: 868 milhões de toneladas de $\mathrm{CO}_{2} \mathrm{eq}$;

(iii) Agropecuária: 730 milhões de toneladas de $\mathrm{CO}_{2}$ eq; e

(iv) Processos industriais e tratamento de resíduos: 234 milhões de toneladas de $\mathrm{CO}_{2} \mathrm{eq}$.

\footnotetext{
${ }^{17}$ Já descontadas as remoções de $\mathrm{CO}_{2}$ realizadas pelas atividades de manejo de áreas protegidas, reflorestamento, abandono de terras manejadas e aumento de estoque de carbono nos solos.

${ }^{18}$ Tal como o PDE.

${ }^{19}$ Regulamenta os artigos $6^{\circ}, 11$ e 12 da Lei $n^{\circ} 12.187$, de 29 de dezembro de 2009, que institui a PNMC, e dá outras providências.

${ }^{20}$ A memória de cálculo das estimativas, assim como as fontes dos dados utilizados, consta do Anexo do Decreto Federal n ${ }^{\circ} 7390 / 2010$.

${ }^{21}$ De acordo com glossário constante da página de internet do Instituto de Pesquisa Ambiental da Amazônia (IPAM), o carbono equivalente ("CO $\mathrm{C}_{2}$ eq") "[É] uma medida métrica utilizada para comparar as emissões de vários Gases de Efeito Estufa [baseada] no potencial de aquecimento global de cada um definido na decisão 2/COP 3 ou conforme revisado subsequentemente de acordo com o Artigo 5. O dióxido de carbono equivalente é o resultado da multiplicação das toneladas emitidas de gases de efeito estufa (GEE) pelo seu potencial de aquecimento global. Por exemplo, o potencial de aquecimento global do gás metano é 21 vezes maior do que o potencial do $\mathrm{CO}_{2}$. Então, dizemos que o $\mathrm{CO}_{2}$ equivalente do metano é igual a 21 ”. Disponível em: <http://www.ipam.org.br/saiba-mais/glossariotermo/CO2-equivalente-CO2e-/15>. Acesso em 17 de julho de 2011.
} 
A tabela abaixo traz a comparação entre as emissões de GEE em 2005, de acordo com o Segundo Inventário Brasileiro e as projeções das emissões de 2020, publicadas no Decreto Federal $n^{\circ} 7.390 / 2010$.

Tabela 1. Emissões de GEE em 2005 e projeções das emissões em 2020.

\begin{tabular}{|c|c|c|}
\hline \multirow[t]{2}{*}{ Setores do Inventário Nacional } & $\begin{array}{c}\text { Emissões } 2005 \\
\text { (Segundo Inventário Nacional) }\end{array}$ & $\begin{array}{c}\text { Projeção emissões em } 2020 \\
\text { Decreto Federal nº 7.390/2010 }\end{array}$ \\
\hline & \multicolumn{2}{|c|}{ (Milhões de $\mathrm{t} \mathrm{CO}_{2} \mathrm{eq}$ ) } \\
\hline $\begin{array}{l}\text { Mudança do Uso da Terra e } \\
\text { Florestas }\end{array}$ & 1.329 & 1.404 \\
\hline Agropecuária & 416 & 730 \\
\hline Energia & 329 & 868 \\
\hline Processos Industriais & 78 & \\
\hline Tratamento de Resíduos & 41 & 234 \\
\hline Total & 2.193 & 3.236 \\
\hline
\end{tabular}

Fonte: (BRASIL, 2012d)

Aplicando-se os percentuais de 36,1\% (trinta e seis por cento e um décimo) e 38,9\% (trinta e oito por cento e nove décimos) de desvio da projeção estimada, o País objetiva evitar, até 2020 , emissões entre 1.168 milhões de toneladas de $\mathrm{CO}_{2}$ eq e 1.259 milhões de toneladas de $\mathrm{CO}_{2} \mathrm{eq}^{22}$.

O Decreto Federal $n^{\circ} 7.390 / 2010$ enuncia algumas ações que devem ser implantadas para o cumprimento do compromisso nacional voluntário, constantes dos Planos de Ação para Prevenção e Controle de Desmatamento nos Biomas ("Planos de Prevenção ao Desmatamento") e Planos Setoriais previstos no artigo $3^{\circ}$ do decreto ${ }^{23}$ :

\footnotetext{
${ }^{22}$ Artigo 6 ${ }^{\circ}$, do Decreto Federal $n^{\circ} 7390 / 2010$.

${ }^{23}$ Plano de Ação para a Prevenção e Controle do Desmatamento na Amazônia Legal - PPCDAm; Plano de Ação para a Prevenção e Controle do Desmatamento e das Queimadas no Cerrado - PPCerrado; Plano Decenal de Expansão de Energia - PDE; Plano para a Consolidação de uma Economia de Baixa Emissão de Carbono na Agricultura; e Plano de Redução de Emissões da Siderurgia.
} 
I - redução de oitenta por cento dos índices anuais de desmatamento na Amazônia Legal em relação à média verificada entre os anos de 1996 a 2005 ;

II - redução de quarenta por cento dos índices anuais de desmatamento no Bioma Cerrado em relação à média verificada entre os anos de 1999 a 2008;

III - expansão da oferta hidroelétrica, da oferta de fontes alternativas renováveis, notadamente centrais eólicas, pequenas centrais hidroelétricas e bioeletricidade, da oferta de biocombustíveis, e incremento da eficiência energética;

IV - recuperação de 15 milhões de hectares de pastagens degradadas;

V - ampliação do sistema de integração lavoura-pecuária-floresta em 4 milhões de hectares;

VI - expansão da prática de plantio direto na palha em 8 milhões de hectares;

VII - expansão da fixação biológica de nitrogênio em 5,5 milhões de hectares de áreas de cultivo, em substituição ao uso de fertilizantes nitrogenados;

VIII - expansão do plantio de florestas em 3 milhões de hectares;

IX - ampliação do uso de tecnologias para tratamento de 4,4 milhões de $\mathrm{m}^{3}$ de dejetos de animais; $\mathrm{e}$

$X$ - incremento da utilização na siderurgia do carvão vegetal originário de florestas plantadas e melhoria na eficiência do processo de carbonização.

Se a forma como a PNMC havia fixado o compromisso de redução, por meio de aplicação de percentual em relação à projeção de emissões, dava margem ao entendimento de que a meta significaria um desvio relativo ao crescimento das emissões, o decreto esclarece que a meta é absoluta. A partir da publicação do decreto, o País adotou o compromisso de reduzir, no mínimo, 1.168 milhões de toneladas de $\mathrm{CO}_{2}$ eq. A partir desta meta é que deverão ser deduzidas as metas gradativas setoriais, das quais trataremos no próximo capítulo. 


\section{TRATAMENTO SETORIAL PARA A PROTEÇÃO DO CLIMA}

\subsection{Planos setoriais de mitigação e de adaptação às mudanças climáticas}

Fixado o compromisso nacional voluntário de redução de emissões, que foi devidamente quantificado pelo Decreto Federal $n^{\circ} 7.390 / 2010$, a PNMC determina que o Poder Executivo estabeleça Planos Setoriais com a finalidade de consolidar uma "economia de baixo consumo de carbono" para as seguintes atividades econômicas ${ }^{24}$ :

(i) geração e distribuição de energia elétrica;

(ii) transporte público urbano e sistemas modais de transporte interestadual de cargas e passageiros;

(iii) indústria de transformação e de bens de consumo duráveis;

(iv) indústrias químicas fina e de base;

(v) indústria de papel e celulose;

(vi) mineração;

(vii) indústria da construção civil;

(viii) serviços de saúde; e

(ix) agropecuária.

Nesta dissertação, utilizaremos a expressão atividades econômicas como equivalente a setores econômicos, sendo tratados tais termos indistintamente.

\footnotetext{
${ }^{24}$ Ipsis literis: "Art. 11. Os princípios, objetivos, diretrizes e instrumentos das políticas públicas e programas governamentais deverão compatibilizar-se com os princípios, objetivos, diretrizes e instrumentos desta Política Nacional sobre Mudança do Clima.

Parágrafo único. Decreto do Poder Executivo estabelecerá, em consonância com a Política Nacional sobre Mudança do Clima, os Planos setoriais de mitigação e de adaptação às mudanças climáticas visando à consolidação de uma economia de baixo consumo de carbono, na geração e distribuição de energia elétrica, no transporte público urbano e nos sistemas modais de transporte interestadual de cargas e passageiros, na indústria de transformação e na de bens de consumo duráveis, nas indústrias químicas fina e de base, na indústria de papel e celulose, na mineração, na indústria da construção civil, nos serviços de saúde e na agropecuária, com vistas em atender metas gradativas de redução de emissões antrópicas quantificáveis e verificáveis, considerando as especificidades de cada setor, inclusive por meio do Mecanismo de Desenvolvimento Limpo - MDL e das Ações de Mitigação Nacionalmente Apropriadas - NAMAs".
} 
Os Planos Setoriais visam atender a metas gradativas de redução de emissões antrópicas "quantificáveis e verificáveis, considerando as especificidades de cada setor" 25 . Para o cumprimento de tais metas, a serem fixadas pelos próprios Planos Setoriais, a PNMC expressa a possibilidade de utilização do MDL e das NAMAs, mecanismos originados do regime internacional de proteção do clima, já mencionados nesta dissertação.

Ao regulamentar a PNMC, o Decreto Federal n ${ }^{\circ} 7.390 / 2010$ dispõe, no artigo $2^{\circ}$, que os Planos Setoriais integrarão, juntamente com os Planos de Prevenção ao Desmatamento, o Plano Nacional sobre Mudança do Clima. O decreto define dois Planos de Prevenção ao Desmatamento (o Plano de Ação para a Prevenção e Controle do Desmatamento na Amazônia Legal - "PPCDAm" e o Plano de Ação para a Prevenção e Controle do Desmatamento e das Queimadas no Cerrado - "PPCerrado") e três Planos Setoriais (o PDE ${ }^{26}$; o Plano ABC; e o Plano de Redução de Emissões da Siderurgia.

Embora enunciado como Plano Setorial, o PDE é anualmente publicado pela Empresa de Pesquisa Energética desde 2006, como ferramenta de planejamento governamental para o setor de energia. O PDE reúne dados sobre a projeção da oferta e da demanda de energia no País para os dez anos seguintes, permitindo que o governo vislumbre a necessidade de investimentos públicos e privados em novos empreendimentos que atendam ao imperativo do desenvolvimento.

O Plano ABC é fruto da coordenação da Casa Civil da Presidência da República, do Ministério da Agricultura, Pecuária e Abastecimento e do Ministério do Desenvolvimento Agrário. Trata-se de documento que reúne programas de atividades que visam mitigar as emissões de GEE na agropecuária, a serem desenvolvidos pelo Poder Público e pela sociedade. O monitoramento da implementação do Plano ABC está a cargo da Comissão Executiva $\mathrm{ABC}$, que deveria ter sido criada no âmbito do CIM.

O Plano de Redução de Emissões da Siderurgia, embora enunciado pelo Decreto Federal $\mathrm{n}^{\circ}$ 7.390/2010, não havia sido publicado até o momento da finalização desta dissertação, restando prejudicada a sua análise.

\footnotetext{
25 Artigo 11 da PNMC.

${ }^{26}$ Disponível em: <http://www.epe.gov.br/PDEE/Forms/EPEEstudo.aspx>. Acesso em 1 de maio de 2012.
} 
Os demais Planos Setoriais previstos pela $\mathrm{PNMC}^{27}$ deveriam ter sido publicados, inicialmente, até 15 de dezembro de 2011. Contudo, o Decreto Federal n ${ }^{\circ} 7.643$, de 11 de dezembro de 2011 prorrogou a data para 16 de abril de 2012. Mais uma vez superada a data em que deveriam ter sido publicados tais Planos Setoriais, enfim, em 15 de junho de 2012, quatro planos foram publicados em suas versões preliminares para consulta pública: (i) Plano Setorial de Mitigação da Mudança Climática para a Consolidação de uma Economia de Baixa Emissão de Carbono na Indústria de Transformação ("Plano Setorial da Indústria"); (ii) Plano de Mineração de Baixa Emissão de Carbono ("Plano Setorial da Mineração"); (iii) Plano Setorial de Transporte e de Mobilidade Urbana para Mitigação da Mudança do Clima ("Plano Setorial do Transporte"); e (iv) Plano Setorial da Saúde para Mitigação e Adaptação à Mudança do Clima ("Plano Setorial da Saúde"). A consulta pública estendeu-se até 15 de agosto de 2012 .

Os Planos Setoriais devem resultar de processo democrático, com ampla consulta pública a ser realizada junto aos setores associados, contemplando "em especial a representação das atividades econômicas diretamente afetadas" ${ }^{28}$. É de se esperar que a adesão do setor privado aos Planos Setoriais, independentemente da forma como serão impostos pelo Poder Público, será maior ou menor a depender da legitimidade angariada pelo seu processo de elaboração e da proximidade de seus dispositivos com a realidade econômica nacional.

O Decreto Federal $n^{\circ} 7.390 / 2010$ traça o conteúdo mínimo dos Planos Setoriais, organizados em: (i) meta de redução de emissões em 2020, expressas em percentuais das projeções previstas para este ano (incluindo metas gradativas com intervalo máximo de três anos); (ii) ações a serem implementadas; (iii) definição de indicadores para o monitoramento e avaliação de sua efetividade; (iv) proposta de instrumentos de regulação e incentivo para implementação do respectivo Plano Setorial; e (v) estudos setoriais de competitividade com estimativa de custos e impactos. As metas contidas nos Planos Setoriais poderão ser utilizadas como parâmetros para o estabelecimento do MBRE, conforme dispõe o artigo $4^{\circ}, \S^{\circ}$, do Decreto Federal n ${ }^{\circ} 7.390 / 2010$.

\footnotetext{
${ }^{27}$ São eles: transporte público urbano e sistemas modais de transporte interestadual de cargas e passageiros; indústria de transformação e de bens de consumo duráveis, indústrias químicas fina e de base, indústria de papel e celulose, mineração, indústria da construção civil, serviços de saúde e agropecuária.

${ }^{28}$ Artigo $4^{\circ}$, parágrafo $1^{\circ}$, da PNMC.
} 
Com base no que expusemos até o momento, a tabela abaixo sintetiza a relação existente entre (i) os setores para os quais a PNMC exigiu Plano Setorial; (ii) as principais fontes emissoras ${ }^{29}$ de cada setor listado na PNMC, conforme dados do Segundo Inventário Brasileiro; (iii) os Planos Setoriais enunciados pelo Decreto Federal $\mathrm{n}^{\circ}$ 7.390/2010; e, finalmente, (iv) as projeções de emissões para 2020 publicadas pelo Decreto Federal $\mathrm{n}^{\circ}$ $7.390 / 2010$.

Tabela 2. Relação entre Planos Setoriais, Segundo Inventário Brasileiro, Planos Setoriais enunciados pelo Decreto Federal n $7.390 / 2010$ e projeção de emissões para 2020.

\begin{tabular}{|c|c|c|c|}
\hline $\begin{array}{l}\text { Planos Setoriais previstos } \\
\text { na PNMC }\end{array}$ & $\begin{array}{l}\text { Principais fontes emissoras } \\
\text { de cada setor, conforme o } \\
\text { Segundo Inventário } \\
\text { Brasileiro }\end{array}$ & $\begin{array}{l}\text { Planos Setoriais } \\
\text { mencionados no Decreto } \\
\text { Federal } n^{\circ} 7.390 / 2010\end{array}$ & $\begin{array}{l}\text { Projeção de emissões } \\
\text { para } 2020\end{array}$ \\
\hline $\begin{array}{l}\text { Indústria de transformação } \\
\text { e de bens de consumo } \\
\text { duráveis }\end{array}$ & $\begin{array}{l}\text { Produção de ferro-gusa e } \\
\text { aço / Produção de alumínio } \\
\text { / Outras indústrias. }\end{array}$ & $\begin{array}{l}\text { Plano de Redução de } \\
\text { Emissões da Siderurgia } \\
\text { Demais planos até } 16 \text { de } \\
\text { abril de } 2012 .\end{array}$ & \multirow{5}{*}{$\begin{array}{l}\text { Processos industriais } \\
\text { e tratamento de } \\
\text { resíduos: } 234 \text { milhões } \\
\text { de toneladas de } \\
\mathrm{CO}_{2} \text { eq. }\end{array}$} \\
\hline $\begin{array}{l}\text { Indústria de Construção } \\
\text { Civil }\end{array}$ & $\begin{array}{l}\text { Produção de Cimento / } \\
\text { Produção de Cal. }\end{array}$ & $\begin{array}{l}\text { A ser publicado até } 16 \text { de } \\
\text { abril de } 2012 \text {. }\end{array}$ & \\
\hline $\begin{array}{l}\text { Indústria de papel e } \\
\text { celulose }\end{array}$ & $\begin{array}{l}\text { Emissões não advindas da } \\
\text { queima de combustíveis } \\
\text { fósseis. }\end{array}$ & $\begin{array}{l}\text { A ser publicado até } 16 \text { de } \\
\text { abril de } 2012 \text {. }\end{array}$ & \\
\hline Não previsto. & Lixo e Esgoto. & Não previsto. & \\
\hline $\begin{array}{l}\text { Indústria química fina e de } \\
\text { base }\end{array}$ & $\begin{array}{l}\text { Produção de amônia; } \\
\text { Produção de ácido nítrico; } \\
\text { e Produção de ácido } \\
\text { adípico. }\end{array}$ & $\begin{array}{l}\text { A ser publicado até } 16 \text { de } \\
\text { abril de } 2012 \text {. }\end{array}$ & \\
\hline $\begin{array}{l}\text { Geração e distribuição de } \\
\text { energia elétrica }\end{array}$ & $\begin{array}{l}\text { Queima de combustíveis } \\
\text { fósseis. }\end{array}$ & $\begin{array}{l}\text { Plano Decenal de } \\
\text { Expansão de Energia - } \\
\text { PDE }\end{array}$ & \\
\hline
\end{tabular}

${ }^{29}$ Como já mencionado na introdução desta dissertação, adotaremos o conceito de fonte emissora empregado na Resolução n ${ }^{\circ}$ 382, aprovada pelo Conselho Nacional de Meio Ambiente ("CONAMA"), em 26 de dezembro de 2006, para a qual fonte fixa de emissão é "qualquer instalação, equipamento ou processo, situado em local fixo, que libere ou emita matéria para a atmosfera, por emissão pontual ou fugitiva”. 


\begin{tabular}{|c|c|c|c|}
\hline $\begin{array}{l}\text { Transporte público urbano } \\
\text { e sistemas modais de } \\
\text { transporte interestadual de } \\
\text { cargas e passageiros }\end{array}$ & $\begin{array}{l}\text { Queima de combustíveis } \\
\text { fósseis. }\end{array}$ & $\begin{array}{l}\text { A ser publicado até } 16 \text { de } \\
\text { abril de } 2012 \text {. }\end{array}$ & \multirow{4}{*}{$\begin{array}{l}\text { Energia: } 868 \text { milhões } \\
\text { de toneladas de } \\
\mathrm{CO}_{2} \text { eq. }\end{array}$} \\
\hline $\begin{array}{l}\text { Indústrias químicas fina e } \\
\text { de base }\end{array}$ & $\begin{array}{l}\text { Queima de combustíveis } \\
\text { fósseis. }\end{array}$ & $\begin{array}{l}\text { A ser publicado até } 16 \text { de } \\
\text { abril de } 2012 \text {. }\end{array}$ & \\
\hline Mineração & $\begin{array}{l}\text { Emissões fugitivas da } \\
\text { mineração de carvão / } \\
\text { Extração e transporte de } \\
\text { óleo e gás natural. }\end{array}$ & $\begin{array}{l}\text { A ser publicado até } 16 \text { de } \\
\text { abril de } 2012 \text {. }\end{array}$ & \\
\hline Não previsto. & $\begin{array}{l}\text { Consumo de energia em } \\
\text { residências. }\end{array}$ & Não previsto. & \\
\hline Agropecuária & $\begin{array}{l}\text { Queima de combustíveis } \\
\text { fósseis / Manejo de } \\
\text { Dejetos Animais; } \\
\text { Fermentação Entérica; } \\
\text { Solos Agrícolas; Queima } \\
\text { de Resíduos Agrícolas. }\end{array}$ & $\begin{array}{l}\text { Plano para a } \\
\text { Consolidação de uma } \\
\text { Economia de Baixa } \\
\text { Emissão de Carbono na } \\
\text { Agricultura }\end{array}$ & $\begin{array}{l}\text { Agropecuária: } 730 \\
\text { milhões de toneladas } \\
\text { de } \mathrm{CO}_{2} \mathrm{eq}\end{array}$ \\
\hline Serviços de Saúde & Não foram avaliadas. & $\begin{array}{l}\text { A ser publicado até } 15 \text { de } \\
\text { dezembro de } 2011 .\end{array}$ & Não prevista. \\
\hline
\end{tabular}

Fonte: elaborada pela autora.

A análise da tabela acima nos permite tecer alguns comentários:

(i) Embora as fontes de emissão do setor de tratamento de resíduos tenham sido avaliadas pelo Segundo Inventário Brasileiro como importante fonte de metano, cujas emissões foram computadas na projeção de emissões para 2020, a PNMC não exigiu a elaboração de Plano Setorial correspondente. De qualquer forma, é esperado que os objetivos da Política Nacional de Resíduos Sólidos de "não geração, redução, reutilização, reciclagem e tratamento dos resíduos sólidos, bem como disposição final ambientalmente adequada dos rejeitos"30 contribuam com a redução de emissões de GEE nesse setor.

${ }^{30}$ Artigo $7^{\circ}$, inciso II, da Lei Federal $n^{\circ} 12.305$, de 02 de agosto de 2010. 
(ii) O Segundo Inventário Brasileiro avalia que o consumo de energia nas residências tenha gerado emissão de $15.484 \mathrm{Gg}$ de $\mathrm{CO}_{2}$ em 2005. O PDE 2019, utilizado como base para projeção das emissões brasileiras em 2020, posiciona o setor residencial como responsável por 10,8\% (dez por cento e oito décimos) do consumo final energético em 2010 e por 8,6\% (oito por cento e seis décimos) em 2019. Embora tenha sido previsto Plano Setorial para geração e distribuição de energia, a PNMC não exigiu políticas específicas voltadas à redução de emissões de GEE em residências. Constata-se, portanto, que a PNMC não engajou o consumidor residencial nos esforços para alcançar o compromisso nacional voluntário de redução de $\mathrm{GEE}^{31}$.

(iii) Com relação aos serviços de saúde, o Segundo Inventário estabelece a quantidade de emissões de $\mathrm{CO}_{2}(110 \mathrm{Gg}$ em 2005) e de N2O (0,0068 Gg em 2005) liberadas pela incineração de resíduos sólidos, provenientes tanto do setor de serviços de saúde quanto do setor industrial. Caso entendamos que o setor de serviços de saúde contribua com a emissão de gases advindos da incineração de seus dejetos, o Plano Setorial dos serviços de saúde exigido pela PNMC deveria ter sido tratado em conjunto com o Plano Setorial de tratamento de resíduos, não previsto pela política, como acima exposto.

(iv) Por fim, observa-se que os setores elencados pela PNMC são amplos e contemplam diversas fontes emissoras de GEE. Para que os Planos Setoriais considerem as especificidades de cada setor, como disposto no artigo 11 da PNMC, é necessário que cada uma de suas fontes de emissão associada seja identificada e considerada em seu contexto econômico próprio.

\footnotetext{
${ }^{31}$ Abordagem diferente foi empregada pela Política Nacional de Resíduos Sólidos instituída pela Lei Federal n ${ }^{\circ}$ $12.305 / 10$, que corresponsabiliza o consumidor final pelo gerenciamento de resíduos sólidos gerados pelas embalagens dos produtos consumidos.
} 


\subsubsection{Conteúdo mínimo dos Planos Setoriais}

A seguir, analisaremos os itens que devem constar obrigatoriamente nos Planos Setoriais, conforme definido pelo Decreto Federal nº 7.390/2010.

\section{(i) Meta de redução de emissões em 2020 e metas gradativas intermediárias}

O Plano Setorial deve contemplar meta de redução de emissões para o setor, expressa em percentual de redução das emissões projetadas para 2020. Deve prever ainda metas gradativas com intervalo máximo de três $\operatorname{anos}^{32}$. Como já visto, tais metas devem ser quantificáveis e verificáveis, considerando-se as especificidades de cada setor ${ }^{33}$.

Nesse sentido, a definição de meta de redução de emissões pressupõe pelo menos o desenvolvimento de três etapas anteriores, quais sejam: (i) a identificação das fontes emissoras abrangidas pelo setor; (ii) a realização de um inventário das emissões liberadas por tais fontes em dado período histórico; e (iii) a projeção das emissões do setor no ano de 2020.

Como já exposto, cada setor enunciado pela PNMC abrange diversas fontes emissoras. Como exemplo, vimos na Tabela 2 que o Plano Setorial da Indústria Química Fina e de Base deve abarcar tanto os processos produtivos que emitem Gases de Efeito Estufa a partir da combustão de combustíveis fósseis quanto aqueles que emitem esses gases no processo de transformação da matéria-prima no produto final ${ }^{34}$.

Com base no Segundo Inventário Brasileiro e nas informações coletadas mediante ampla consulta pública junto aos setores associados ${ }^{35}$, devem ser identificadas as fontes de emissão a ele associadas a serem compreendidas por cada Plano Setorial.

Superada esta primeira etapa, faz-se necessária a adoção de metodologia uniforme para mensurar as emissões das fontes identificadas, de forma que os dados coletados possam ser comparáveis entre si.

\footnotetext{
${ }^{32}$ Artigo $4^{\circ}$, inciso I e parágrafo $2^{\circ}$, do Decreto Federal n ${ }^{\circ} 7.390 / 2010$.

33 Artigo 11, parágrafo único.

${ }^{34}$ O Segundo Inventário enumera, entre os processos produtivos da indústria química que emitem GEE não originados da queima de combustíveis fósseis, a produção de amônia, a produção de ácido nítrico e a produção de ácido adípico.

${ }^{35}$ Artigo $4^{\circ}$, parágrafo $1^{\circ}$, da PNMC.
} 
Havendo dados concretos sobre as emissões do setor em dado período histórico, será, então, possível estimar suas emissões para 2020 e delimitar percentual de redução em relação às projeções desse ano. Com base no percentual de redução fixado para 2020, devem ser traçadas metas gradativas com intervalo máximo de três anos.

A Confederação Nacional da Indústria (“CNI”), em dezembro de 2011, lançou o manifesto Contribuições Preliminares para Regulamentação da PNMC: Plano Indústria (CNI, 2011), em que manifestou as preocupações e estabeleceu as propostas da indústria nacional para o processo em andamento.

A CNI propôs como passo inicial para a criação dos Planos Setoriais a identificação das emissões da indústria, por meio de uma abordagem bottom up ${ }^{36}$, isto é, a partir da mensuração das emissões nas fontes emissoras consideradas individualmente. Propôs a criação de um sistema nacional de monitoramento, relato e verificação de emissões que garanta credibilidade e transparência, a partir do qual devem ser definidos os compromissos de redução.

Com relação ao primeiro item do conteúdo mínimo dos Planos Setoriais, a CNI defende que os compromissos de redução sejam estabelecidos após um período de três anos, nos quais as ações previstas nos demais itens do conteúdo mínimo seriam executadas. Ainda segundo a CNI, tais compromissos devem variar de setor para setor, de acordo com a capacidade técnico-financeira de cada qual para reduzir emissões, sendo sempre voltados à eficiência da indústria, de forma a não impedir o aumento da produção.

\section{(ii) Ações a serem implementadas}

Fixada a meta setorial de redução para 2020 e as respectivas metas gradativas, o Plano Setorial deverá indicar as ações a serem implementadas para seu alcance. É neste item que deverá ser exposta a forma pela qual cada fonte emissora contribuirá para o alcance da meta setorial.

\footnotetext{
${ }^{36}$ Segundo Stern, a chamada abordagem bottom up estuda as opções individuais em diferente setores, mas não atenta à modelagem macroeconômica. A abordagem top down, por sua vez, trabalha com menos detalhes individuais e propõe uma modelagem macroeconômica, envolvendo as emissões gerais de cada setor (STERN, 2009).
} 
Levando-se em consideração que a PNMC determina que as metas setoriais sejam quantificáveis e verificáveis, deduz-se que as ações a serem implementadas devam ser traduzidas em limites de emissões máximas individuais para cada fonte emissora a cada três anos e no ano de 2020.

Para a CNI, os primeiros três anos de vigência dos Planos Setoriais deverão contemplar as seguintes ações (CNI, 2011):

(i) Anos 2012-2013:

a. Desenvolvimento de estudos específicos para definição das linhas de base dos setores industriais contemplados, considerando as projeções de crescimento dos setores para 2020;

b. Desenvolvimento de estudos específicos com avaliações sócio e técnicoeconômicas de possíveis medidas de redução de emissões em cada setor (contemplando, inter allia, projetos de eficiência energética, processos industriais, substituição de combustíveis e manejo de resíduos);

c. Desenvolvimento de Programas buscando sempre o alinhamento com programas, políticas ou planos que apresentem benefícios sinérgicos à PNMC como, por exemplo: Plano Nacional de Eficiência Energética e Política Nacional de Resíduos Sólidos.

(ii) Ano 2014:

a. Padronização de procedimentos de monitoramento;

b. Criação de registro público de emissões nacional.

Portanto, na visão da CNI, o primeiro triênio de vigência dos Planos Setoriais deverá ser dedicado à coleta dos dados necessários para a definição das metas setoriais e preparação de programas de ações para alcançá-las. 


\section{(iii) Definição de indicadores para o monitoramento e avaliação de sua efetividade}

A definição de indicadores para o monitoramento e avaliação da efetividade dos Planos Setoriais é imprescindível para que as metas gradativas de redução de emissões sejam verificáveis, como determina a PNMC.

A uniformidade de indicadores para cada setor é necessária para garantir a comparabilidade dos dados obtidos para cada fonte emissora ao final de cada período de três anos e em 2020. Dessa forma, será possível verificar, a cada período, quais os setores que estão a caminho do alcance das metas propostas e, por outro lado, quais são aqueles setores que ainda deverão empreender esforços adicionais para efetivar seus planos, facilitando o direcionamento de recursos econômicos e de políticas públicas.

Nesse sentido, a CNI propõe que indicadores sejam criados para medir a intensidade de emissões por unidade de produção adequada para cada processo industrial, garantindo a comparabilidade de informações entre as empresas de um mesmo setor (CNI, 2011).

\section{(iv) Proposta de instrumentos de regulação e incentivo para sua implementação}

A PNMC prevê como uma de suas diretrizes a adoção de instrumentos financeiros e econômicos que promovam ações de mitigação e de adaptação à mudança do clima ${ }^{37}$.

Alguns destes instrumentos estão expressamente mencionados na PNMC, a saber: (i) medidas fiscais e tributárias destinadas a estimular a redução das emissões e remoção de GEE, incluindo alíquotas diferenciadas, isenções, compensações e incentivos ${ }^{38}$; (ii) linhas de crédito e financiamento específicas de agentes financeiros públicos e privados ${ }^{39}$; (iii) mecanismos financeiros e econômicos referentes à mitigação da mudança do clima e à adaptação aos efeitos da mudança do clima que existam no âmbito da Convenção do Clima e do Protocolo de Quioto $^{40}$; e (iv) mecanismos financeiros e econômicos, no âmbito nacional, referentes à mitigação e à adaptação à mudança do clima ${ }^{41}$.

\footnotetext{
${ }^{37}$ Artigo $5^{\circ}$, VII, da PNMC.

${ }^{38}$ Artigo $6^{\circ}$, VI, da PNMC.

${ }^{39}$ Artigo $6^{\circ}$, VII, da PNMC.

${ }^{40}$ Artigo $6^{\circ}, \mathrm{X}$, da PNMC.

${ }^{41}$ Artigo $6^{\circ}, \mathrm{XI}$, da PNMC.
} 
Diante das peculiaridades das ações a serem implantadas por cada setor para o alcance de suas metas, deverão ser previstos os instrumentos de incentivos mais adequados às possibilidades concretas de redução de emissões.

A CNI propõe como principais instrumentos de regulação para o triênio 2012-2014 (CNI, 2011):

(i) Divulgação, estruturação e, se necessário, ampliação das linhas de financiamento existentes direcionadas a projetos de redução de emissões de GEE e eficiência energética, favorecendo a superação de eventuais barreiras à implementação destes projetos;

(ii) Definição de instrumentos fiscais que propiciem o aumento de investimentos em eficiência energética na indústria; e

(iii) Criação de registro único nacional de emissões de GEE da indústria.

Note-se que os instrumentos propostos pela CNI consistem em incentivos e estruturas de suporte às atividades da iniciativa privada, não sendo previstos instrumentos de comando-econtrole.

\section{(v) Estudos setoriais de competitividade com estimativa de custos e impactos}

O Plano Setorial deverá considerar as estimativas de custo associadas ao alcance da meta setorial, assim como os impactos desses custos para a competitividade da indústria nacional.

Estudo organizado pelo Banco Mundial, denominado Estudo de Baixo Carbono para o Brasil (Gouvello, 2010), apresentou opções para a redução de emissões em diversos setores da economia brasileira, a partir da análise do cenário de referência e projeções para os anos seguintes. O estudo analisa os resultados que podem ser alcançados em termos de redução de emissões a partir da adoção de medidas de mitigação identificadas e quantifica os investimentos necessários para tanto, permitindo uma análise do custo-benefício de cada medida proposta. 
A título de ilustração, uma das conclusões do estudo do Banco Mundial é de que nos setores de energia e de transportes é mais difícil reduzir as emissões, considerando-se que estas já estão em níveis baixos, de acordo com os padrões internacionais, devido ao emprego da hidroeletricidade e do etanol (GouvelLo, 2010, p. 28).

Com base em estudos similares, o Poder Público poderá identificar para quais setores econômicos a adoção de medidas de mitigação produz resultados mais efetivos a custos menores para a sociedade.

A CNI propõe que os estudos trazidos pelos Planos Setoriais identifiquem os custos, riscos e impactos que a adoção de medidas de mitigação poderão ter sobre a competitividade de cada setor, assim como definam as salvaguardas para aqueles mais sensíveis à competição internacional (CNI, 2011). Segundo a confederação, os estudos ainda devem contemplar

comparação entre a intensidade de emissões e emissões totais dos setores nacionais com as dos setores similares em outros países, com o objetivo de avalizar o impacto nas emissões globais associadas a determinados produtos, caso estes deixem de ser produzidos no país ou passem a ser produzidos no Brasil. (CNI, 2011)

Questão interessante levantada pela CNI é a da possibilidade das metas de redução de emissões para determinados setores provocarem o deslocamento de atividades econômicas para países em que a legislação ambiental é menos rigorosa. Vale lembrar que, sob a ótica do problema global da mudança do clima, as emissões de GEE realizadas no Brasil ou em qualquer outro país do globo gera os mesmos resultados deletérios.

Nesse sentido, para que as medidas adotadas nacionalmente não desloquem simplesmente as fontes emissoras de um lugar para outro, é preciso que os Planos Setoriais considerem em até que medida a meta de redução setorial incentiva o setor produtivo a reduzir emissões e, a partir de que ponto os custos associados à adoção de medidas mitigadoras tornam a permanência da indústria no território nacional proibitiva, provocando a transferência das fontes emissoras para outro país, ou mesmo, oferecendo oportunidade para outro produtor estrangeiro suprir a demanda nacional a partir de um processo de elaboração mais intensivo em emissões de GEE. 


\subsection{Fundamento constitucional do tratamento setorial para proteção do clima}

A PNMC impõe ao Poder Público a alocação do ônus da redução de emissões de GEE entre os setores econômicos, considerando-se as "responsabilidades individuais quanto à origem das fontes emissoras e dos efeitos ocasionados sobre o clima"42. Com vista ao atendimento do dispositivo legal, o Poder Executivo deverá estabelecer Planos Setoriais que tomem por base as especificidades de cada setor ${ }^{43}$.

Como demonstraremos a seguir, a Constituição Federal não somente permite o controle de substâncias que possam causar risco à vida e ao meio ambiente, como também ampara a forma escolhida pelo legislador para a distribuição do encargo de redução de emissões entre os setores econômicos.

O caput do artigo $225^{44}$ da Constituição Federal comporta a "norma-matriz" da proteção ambiental, no termo empregado por José Afonso da Silva (SILVA, 2010, p. 52), que garante a todos o direito fundamental ao meio ambiente ecologicamente equilibrado e à sadia qualidade de vida. A norma-matriz é seguida dos “instrumentos de garantia da efetividade do direito enunciado no caput ${ }^{\prime 45}$, dispostos no parágrafo $1^{\circ}$, do artigo 225 , e seus incisos.

\footnotetext{
${ }^{42}$ Segundo o disposto no artigo $3^{\circ}$, inciso III, as medidas tomadas para prever, evitar ou minimizar as causas identificadas da mudança do clima "devem levar em consideração os diferentes contextos socioeconômicos de sua aplicação, distribuir os ônus e encargos decorrentes entre os setores econômicos e as populações e comunidades interessadas de modo equitativo e equilibrado e sopesar as responsabilidades individuais quanto à origem das fontes emissoras e dos efeitos ocasionados sobre o clima". (grifos nossos)

${ }^{43} \mathrm{O}$ artigo 11, parágrafo único, já comentado anteriormente, dispõe:

“Art. 11. Os princípios, objetivos, diretrizes e instrumentos das políticas públicas e programas governamentais deverão compatibilizar-se com os princípios, objetivos, diretrizes e instrumentos desta Política Nacional sobre Mudança do Clima.

Parágrafo único. Decreto do Poder Executivo estabelecerá, em consonância com a Política Nacional sobre Mudança do Clima, os Planos setoriais de mitigação e de adaptação às mudanças climáticas visando à consolidação de uma economia de baixo consumo de carbono, na geração e distribuição de energia elétrica, no transporte público urbano e nos sistemas modais de transporte interestadual de cargas e passageiros, na indústria de transformação e na de bens de consumo duráveis, nas indústrias químicas fina e de base, na indústria de papel e celulose, na mineração, na indústria da construção civil, nos serviços de saúde e na agropecuária, com vistas em atender metas gradativas de redução de emissões antrópicas quantificáveis e verificáveis, considerando as especificidades de cada setor, inclusive por meio do Mecanismo de Desenvolvimento Limpo - MDL e das Ações de Mitigação Nacionalmente Apropriadas - NAMAs". (grifos nossos)

${ }^{44}$ Nos termos do artigo 225, "Todos têm direito ao meio ambiente ecologicamente equilibrado, bem de uso comum do povo e essencial à sadia qualidade de vida, impondo-se ao Poder Público e à coletividade o dever de defendê-lo e preservá-lo para as presentes e futuras gerações".

${ }^{45}$ Ainda utilizando-nos da terminologia empregada por José Afonso da Silva (SILVA, 2010, p. 52).
} 
Dentre os instrumentos constitucionais que visam concretizar o direito fundamental ao meio ambiente ecologicamente equilibrado e à sadia qualidade de vida está o disposto no inciso VIII, consistente no

controle da produção, comercialização e emprego de técnicas, métodos e substâncias que comportem risco para a vida, a qualidade de vida e o meio ambiente, permitindo-se, aí, a interferência do Poder Público no domínio privado, para impedir práticas danosas ao meio ambiente e à saúde da população.

Por meio deste dispositivo, a Constituição Federal recepcionou dois instrumentos da Política Nacional de Meio Ambiente, instituída pela Lei Federal n 6.938, de 31 de agosto de 1981: “o estabelecimento de padrões de qualidade ambiental” (artigo 9, I) e "os incentivos à produção e instalação de equipamentos e a criação ou absorção de tecnologia, voltados para a melhoria da qualidade ambiental" (artigo $\left.9^{\circ}, \mathrm{V}\right)$.

Para regulamentar tais instrumentos, a Política Nacional de Meio Ambiente instituiu o Conselho Nacional do Meio Ambiente (“CONAMA”), a quem compete, a partir de proposição do Instituto Brasileiro do Meio Ambiente e dos Recursos Naturais Renováveis (“IBAMA”), “estabelecer normas, critérios e padrões relativos ao controle e à manutenção da qualidade do meio ambiente com vistas ao uso racional dos recursos ambientais, principalmente os hídricos" (artigo 8, VII).

Com vista a ilustrar a competência do CONAMA para definir padrões de controle ambiental, citamos a Resolução n 382 aprovada pelo órgão colegiado em 26 de dezembro de 2006, que impõe limites máximos de emissões atmosféricas para cada fonte fixa. Tais limites são fixados por categoria de processo produtivo, considerando-se que para cada qual existe um leque de tecnologias disponíveis para a redução de poluentes.

O dispositivo constitucional em comento também fundamenta a intervenção do Poder Público no domínio privado para controlar os métodos produtivos que causem emissão de GEE, gases estes não contemplados na Resolução CONAMA n 382/2006, cuja concentração intensifica a mudança do clima, com efeitos prejudiciais à vida no planeta. 
Em paralelo à PNMA, a PNMC instituiu arcabouço institucional próprio para a aplicação de seus dispositivos ${ }^{46}$, competindo ao Poder Executivo regulamentar os Planos Setoriais, como visto anteriormente ${ }^{47}$. Dessa forma, o CONAMA não possui competência para determinar metas de redução setoriais, que deverão ser definidas mediante decreto federal.

Ao lado do enunciado do artigo 225, a defesa do meio ambiente também é invocada na Constituição Federal como princípio da ordem econômica, conforme disposto no inciso VI, do artigo $170^{48}$.

Cristiane Derani, em sua obra Direito Ambiental Econômico, defende a leitura indissociável das normas previstas no artigo 170 e no artigo 225, da Constituição Federal, para a compreensão do objetivo da ordem econômica constitucional, qual seja, assegurar a todos a existência digna, conforme os ditames da justiça social (DERANI, 2001, p. 243-244). Segundo a autora,

A base do desenvolvimento das relações produtivas está na natureza. E a natureza só pode ser compreendida enquanto integrante das relações humanas - aqui inseridas, com todo o seu peso, as relações econômicas. Esta união visceral, necessariamente, tem de se fazer sentir no interior do ordenamento jurídico. São esses os elementos que suportam a tese de que a

\footnotetext{
${ }^{46}$ De acordo com o artigo $7^{\circ}$, da PNMC: "Os instrumentos institucionais para a atuação da Política Nacional de Mudança do Clima incluem:

I - o Comitê Interministerial sobre Mudança do Clima;

II - a Comissão Interministerial de Mudança Global do Clima;

III - o Fórum Brasileiro de Mudança do Clima;

IV - a Rede Brasileira de Pesquisas sobre Mudanças Climáticas Globais - Rede Clima; V - a Comissão de Coordenação das Atividades de Meteorologia, Climatologia e Hidrologia".

${ }^{47}$ Acerca da nulidade da Instrução Normativa do IBAMA n ${ }^{\circ}$ 07/2009, que dispunha sobre a obrigatoriedade da ação de medidas de mitigação de emissões de dióxido de carbono no âmbito do processo de licenciamento ambiental de termelétricas movidas a carvão e óleo, ver decisão liminar em primeira instância da Justiça Federal, confirmada pelo Tribunal Regional Federal da $1^{\text {a }}$ Região, nos autos do processo ${ }^{\circ}$ 2009.34.00.034475-6, que entendeu ser competência do IBAMA apenas a "edição de atos normativos internos relacionados às atribuições de planejamento, coordenação, controle, orientação e direção das atividades do IBAMA", sendo proibida a imposição de restrição a direitos de particulares.

${ }^{48}$ De acordo com o artigo 170, inciso VI, “A ordem econômica, fundada na valorização do trabalho humano e na livre-iniciativa, tem por fim assegurar a todos existência digna, conforme os ditames da justiça social, observados os seguintes princípios:

VI - defesa do meio ambiente, inclusive mediante tratamento diferenciado conforme o impacto ambiental dos produtos e serviços e de seus processos de elaboração e prestação;".
} 
realização do artigo 225 da Constituição Federal passa pela efetivação do artigo 170 e vice-versa. (DERANI 2001, p. 191)

Para José Afonso da Silva, a submissão da ordem econômica ao princípio da defesa do meio ambiente traduz-se na ideia de que

toda atividade econômica só pode desenvolver-se legitimamente enquanto atende a tal princípio, entre os demais relacionados no art. 170, convocando, no caso de inatendimento, a aplicação da responsabilidade da empresa e de seus dirigentes, na forma prevista no artigo $173, \S 5^{\circ 49}$. (SILVA, 2010, p. 48)

Segundo Eros Grau, o princípio da defesa do meio ambiente tem caráter constitucional conformador, isto é, explicita "valorações políticas fundamentais do legislador constituinte". Segundo o autor, o princípio demanda a realização de políticas públicas voltadas à proteção do meio ambiente, buscando alcançar o desenvolvimento nacional, o pleno emprego e o próprio objetivo da ordem econômica (GRAU, 2002, p. 93-281).

O próprio texto normativo do mencionado inciso VI, cuja redação foi alterada pela Emenda Constitucional $\mathrm{n}^{\circ} 42 / 2003^{50}$, apresenta uma das formas pela qual a defesa do meio ambiente pode ser concretizada no âmbito da ordem econômica, isto é, "mediante tratamento diferenciado conforme o impacto ambiental dos produtos e serviços e de seus processos de elaboração e prestação".

O ditame constitucional do tratamento diferenciado das atividades econômicas com base no impacto ambiental a que dão causa pode ser visto como um reflexo da aplicação do princípio do poluidor-pagador.

\footnotetext{
${ }^{49}$ Dispõe o artigo $173, \S 5^{\circ}$, que a lei deverá estabelecer a responsabilidade da pessoa jurídica, sem prejuízo da responsabilidade individual de seus dirigentes, assim como as punições para os atos praticados contra a ordem econômica e financeira e contra a economia popular.

${ }^{50}$ A Emenda Constitucional n ${ }^{\circ} 42 / 2003$ alterou o Sistema Tributário Nacional.
} 
O princípio do poluidor-pagador é tido pela doutrina jurídica como um dos princípios basilares do direito ambiental brasileiro. A doutrina internacional também reconhece a relevância desse princípio para a proteção do meio ambiente. Maria Alexandra de Sousa Aragão, em sua obra $O$ Princípio do Poluidor Pagador: Pedra Angular da Política Comunitária do Ambiente, leciona:

(...) o PPP [princípio do poluidor-pagador] começou por ser apenas um princípio econômico, visando alcançar a máxima eficácia na internalização dos custos, mas ascendeu posteriormente a princípio geral do direito do ambiente, podendo considerar-se actualmente um princípio de ordem pública ecológica. (ARAGÃO, 1997, p. 211)

A Declaração do Rio sobre Meio Ambiente e Desenvolvimento, assinada ao final da Conferência das Nações Unidas sobre Meio Ambiente e Desenvolvimento, em 1992, consagra o princípio do poluidor-pagador no direito internacional, trazendo a sua melhor definição no princípio 16, a saber:

As autoridades nacionais devem procurar promover a internalização dos custos ambientais e o uso de instrumentos econômicos, tendo em vista a abordagem segundo a qual o poluidor deve, em princípio, arcar com o custo da poluição, com a devida atenção ao interesse público e sem provocar distorções no comércio e nos investimentos internacionais.

Em outras palavras, os custos das medidas hábeis a controlar e mitigar a poluição devem ser arcados por quem a provocou, evitando-se, assim, que tais custos sejam arcados por outros agentes econômicos ou pela sociedade como um todo.

A dimensão preventiva do princípio do poluidor-pagador é reconhecida de forma pacífica pela doutrina (ARAGÃo, 1997, p. 116). Nesse sentido, a sua finalidade precípua é a “prevenção da poluição futura e não a reparação de danos passados” (ARAGÃO, 1997, p. 116).

A Política Nacional de Meio Ambiente adota o princípio do poluidor-pagador como um de seus objetivos. Nos termos do artigo $4^{\circ}$, inciso VII, deverá ser imposta ao "poluidor e 
ao predador", a "obrigação de recuperar e/ou indenizar os danos causados" e ao "usuário", a “contribuição pela utilização de recursos ambientais com fins econômicos".

Importante notar que, a depender da perspectiva pela qual o princípio do poluidorpagador é analisado, pode ser concebido como princípio do usuário-pagador ou do protetorrecebedor. A partir da ideia de que o poluidor deve arcar com os custos da poluição a que deu causa, poupando a sociedade de pagar por medidas ambientais corretivas causadas por um único agente, deduz-se que o usuário de recursos naturais deva pagar pela utilização desses bens, pois se apropriou de recursos de domínio comum. Por outro lado, deduz-se que o agente que contribuiu para a preservação do meio ambiente deve receber pelos serviços que prestou à sociedade.

Para Paulo Affonso Leme Machado, o princípio do poluidor-pagador está contido no princípio do usuário-pagador. Nas palavras do autor,

O princípio [do usuário-pagador] não é uma punição, pois mesmo não existindo qualquer ilicitude no comportamento do pagador ele pode ser implementado. Assim, para tornar obrigatório o pagamento pelo uso do recurso ou pela poluição não há a necessidade de ser provado que o usuário e o poluidor estão cometendo faltas ou infrações. (MACHADO, 2009, p. 67)

O princípio do poluidor-pagador, em sua faceta de usuário-pagador, foi reconhecido pelo Supremo Tribunal Federal, no julgamento da Ação de Inconstitucionalidade $\mathrm{n}^{\circ} 3378$, como fundamento para cobrança da compensação ambiental instituída pela Lei Federal $\mathrm{n}^{\circ}$ 9.985, de 18 de julho de 2000. Segundo o Ministro Carlos Ayres Brito, o princípio do usuáriopagador consiste em "mecanismo de assunção da responsabilidade social (partilhada, insistase) pelos custos ambientais derivados da atividade econômica".

Como reflexo do princípio do poluidor-pagador, o tratamento diferenciado conforme o impacto ambiental das atividades econômicas teria, a nosso ver, como um de seus sentidos, a função de assegurar que a defesa do meio ambiente deverá considerar a internalização dos impactos ambientais pela atividade econômica, estando autorizada a diferenciação da alocação do ônus dos custos ambientais de forma proporcional aos potenciais impactos dos produtos e serviços, assim como dos seus processos de elaboração e prestação. Em outras palavras, o 
agente econômico que provoca impacto ambiental ou que se utiliza de recursos naturais deverá arcar com os custos de sua ação na medida em que deu causa.

O efeito reverso do dispositivo constitucional é reflexo do princípio do protetorrecebedor. Trata-se de princípio em formação no direito ambiental brasileiro, já reconhecido pela Lei Federal $\mathrm{n}^{\circ} 12.305$, de 06 de agosto de 2010, que instituiu a Política Nacional de Resíduos Sólidos ${ }^{51}$.

O princípio do protetor-recebedor tem o sentido contrário ao do poluidor-pagador: visa reconhecer, ou mesmo premiar, os agentes pelas ações que beneficiam o meio ambiente, tidas pela teoria econômica como externalidades positivas da atividade econômica. Ana Maria de Oliveira Nusdeo analisa o princípio do protetor-recebedor como orientador de uma política de pagamento por serviços ambientais (NUSDEO, 2012). Segundo a autora,

A proposta de pagamento ao protetor, assim, trata de retirar da esfera daquele que preserva, total ou parcialmente, os custos de preservação, podendo chegar mesmo a permitir que aufira algum ganho com a proteção. Coloca-se então como o oposto do poluidor-pagador e do usuário-pagador. Essa relação de oposição pode até resultar na contraposição do protetorrecebedor ao poluidor-pagador ou usuário-pagador na relação de pagamento. (NUSDEO, 2012, p. 138)

A interpretação da expressão tratamento diferenciado conforme o impacto ambiental dos produtos e serviços e de seus processos de elaboração e prestação como uma das faces do princípio do protetor-recebedor implica o reconhecimento, pela Constituição Federal, de que as atividades econômicas que resultam em baixo impacto ambiental ou mesmo em benefícios para o meio ambiente também devem ter um tratamento diferenciado.

A doutrina jurídica vem construindo a interpretação desse dispositivo constitucional à luz do direito tributário.

\footnotetext{
${ }^{51}$ O princípio do protetor-recebedor está enunciado no artigo $6^{\circ}$, II, da Lei Federal $n^{\circ} 12.305$, de 02 de agosto de 2010.
} 
Para Birnefeld e outros autores, o dispositivo constitucional encerra o princípio do tratamento tributário ambientalmente diferenciado do contribuinte. Em linha com o princípio da isonomia tributária que ordena tratar os iguais de forma igual e tratar os desiguais de forma desigual, a Constituição Federal permitiria a diferenciação do contribuinte com base nos impactos ambientais da atividade por ele desenvolvida (BIRNEFELD et al., 2011).

No mesmo sentido, Denise Lucena Cavalcante defende que a partir da Emenda Constitucional $n^{\circ} 42 / 2003$ a Constituição Federal permitiria a adoção de benefícios fiscais para as atividades econômicas não poluidoras (CAVALCANTE, 2009).

Parece-nos que o dispositivo constitucional pode ser aplicado não apenas como fundamento da fiscalidade ambiental, mas como norma geral que permite o tratamento diferenciado dos setores econômicos para o fim de elaboração de políticas públicas ambientais com impacto na ordem econômica.

Voltando para o tema da mudança do clima, temos que, à luz do princípio do poluidorpagador, aquele que emitiu GEE deverá arcar com os custos das medidas de mitigação de seus impactos à atmosfera global. Em uma perspectiva preventiva, o princípio do usuário-pagador ordena que o agente que se utiliza das florestas e dos oceanos como sumidouro das emissões de GEE geradas por suas atividades econômicas deve remunerar a sociedade pela utilização desses bens ambientais comuns a todos. Por outro prisma, as ações que contribuem para a redução ou para o sequestro das emissões que intensificam o fenômeno natural deverão ser valorizadas por aqueles que se beneficiam de seus resultados.

Nesse sentido, o dispositivo constitucional autoriza que o estabelecimento de metas setoriais considere "responsabilidades individuais quanto à origem das fontes emissoras e dos efeitos ocasionados sobre o clima"52 para a alocação de metas de redução de GEE. Propomos

\footnotetext{
${ }^{52}$ Segundo o disposto no artigo $3^{\circ}$, inciso III, as medidas tomadas para prever, evitar ou minimizar as causas identificadas da mudança do clima "devem levar em consideração os diferentes contextos socioeconômicos de sua aplicação, distribuir os ônus e encargos decorrentes entre os setores econômicos e as populações e comunidades interessadas de modo equitativo e equilibrado e sopesar as responsabilidades individuais quanto à origem das fontes emissoras e dos efeitos ocasionados sobre o clima". (grifos nossos)
} 
sintetizar esta ideia por meio da expressão proteção do clima mediante o tratamento diferenciado das atividades econômicas ${ }^{53}$ conforme suas emissões.

Por fim, cabe, ainda, mencionar que a norma prevista no parágrafo único do artigo 170 assegura a liberdade do exercício de qualquer atividade econômica, independentemente de autorização de órgãos públicos, salvo nos casos dispostos em lei.

Para Eros Grau, “a legalidade na qual se desdobra o princípio da livre-iniciativa é aquela consagrada no art. 5 II, da CF/1988: 'ninguém será obrigado a fazer ou deixar de fazer alguma coisa senão em virtude de lei"'. Continua o autor:

Por isso algumas vezes se aplicam aos agentes econômicos preceitos dispostos pela própria Administração, no exercício da função normativa, que veiculam a imposição, a eles, de deveres, requisitos ou exigências, porém nos termos e em virtude de lei. Aí se trata de preceitos que impõem deveres, requisitos ou exigências em virtude de lei não obstante essa imposição decorra de ato normativo da Administração, ato que ela porém pratica exercitando autorização para tanto expressamente contida em lei. (GRAU, 1998, p. 97-98)

Utilizando-se da interpretação de Eros Grau, a imposição de metas setoriais para a emissão de GEE no território brasileiro não fere o princípio da livre-iniciativa, uma vez que expressamente autorizada por lei, no caso, a PNMC.

\footnotetext{
${ }^{53}$ Empregamos aqui a expressão atividades econômicas em seu sentido amplo, incluindo aquelas desenvolvidas pelo Estado, no campo dos serviços públicos (GRAU, 2002, p. 146). Os termos atividade econômica e setor econômico são utilizados de forma indistinta.
} 
Cumpre notar que os Planos Setoriais instituídos pela PNMC devem limitar-se a regrar aspectos relacionados à emissão de GEE das atividades econômicas, não intervindo na liberdade dos agentes econômicos de responder às questões fundamentais de o que produzir, como produzir, para quem produzir ${ }^{54}$. Com base no disposto no artigo 174 da Constituição Federal $^{55}$, a função de planejamento econômico estatal deve ser indicativa para o setor privado, mantendo-se a separação dos planos decisórios político e econômico.

\footnotetext{
${ }^{54}$ Segundo o Professor Fabio Nusdeo tais indagações compõem o problema econômico cujo equacionamento pode se dar em três modelos distintos de sistemas econômicos: sistema fundado na tradição, sistema fundado na autoridade e sistema fundado na autonomia. (NUSDEO, 2001, p. 99)

${ }^{55}$ De acordo com o disposto no artigo 174, "Como agente normativo e regulador da atividade econômica, o Estado exercerá, na forma da lei, as funções de fiscalização, incentivo e planejamento, sendo este determinante para o setor público e indicativo para o setor privado".
} 


\section{CRITÉRIOS PARA ALOCAÇÃO DIFERENCIADA DE METAS DE REDUÇÃO POR SETOR E POR FONTE EMISSORA}

Vimos que a PNMC, amparada pela Constituição Federal, orienta o compartilhamento do ônus da mitigação da mudança do clima entre as atividades econômicas com base em critérios que as diferenciem de acordo com as suas respectivas responsabilidades quanto à origem das emissões e efeitos ocasionados ao clima. Propusemos sintetizar este conceito por meio da expressão proteção do clima mediante o tratamento diferenciado das atividades econômicas conforme suas emissões.

A proposta de distinguir o nível de contribuição de cada agente sujeito à obrigação de redução de GEE está enraizada na Convenção do Clima, tendo como fundamento o princípio da responsabilidade comum porém diferenciada ${ }^{56}$. A diferenciação das obrigações às quais os países Partes estão sujeitos no âmbito da Convenção do Clima refletiu em sua divisão entre o grupo dos listados no Anexo I da Convenção (países tidos como desenvolvidos) e aqueles não mencionados em tal Anexo (países considerados em desenvolvimento ou menos desenvolvidos).

Para a chamada Proposta Brasileira ${ }^{57}$, que ganhou destaque durante as negociações do Protocolo de Quioto, o critério de diferenciação das obrigações entre as Partes deveria fundamentar-se em suas respectivas responsabilidades históricas pelo aumento de temperatura média do planeta.

Com base neste critério, os países desenvolvidos, que mais contribuíram ao longo da história com a emissão dos GEE, deveriam liderar o combate às mudanças climáticas, por meio da adoção de compromissos mandatórios mais ambiciosos de redução de emissões. Os países em desenvolvimento, de outro ladro, deveriam imprimir esforços voluntários para deter as mudanças climáticas, com o suporte dos países desenvolvidos.

\footnotetext{
${ }^{56}$ Previsão constante do artigo $3^{\circ}$, parágrafo $1^{\circ}$.

${ }^{57}$ A Proposta Brasileira foi formalizada no documento Proposed Elements of a Protocol to the United Nations Framework on Climate Change (FCCC/AGBM/1997/MISC.1/Add.3), apresentado à COP-3 pelo G-77 e China.
} 
De fato, o Protocolo de Quioto estabeleceu metas quantificadas de redução para os países incluídos no Anexo I, enquanto previu a possibilidade de os países que não figuram no Anexo I participarem dos esforços globais por meio do MDL, como já exposto nesta dissertação.

Contudo, a responsabilidade histórica pelas emissões de GEE não é o critério definitivo para diferenciação dos sujeitos obrigados a adotar medidas que combatam a mudança do clima. A Proposta Brasileira é apenas o critério que convinha aos países em desenvolvimento defender nas negociações pré-Quioto.

Alguns autores analisaram cenários futuros que seriam resultantes da adoção de outros critérios para a definição de metas quantitativas de redução de emissões entre os países. Blanchard, em seu artigo Scenarios for Differentiating Commitments: a Quantative Analysis, estudou, como critérios hipotéticos para a alocação do ônus da mitigação da mudança do clima entre os países, as emissões per capita, as emissões acumuladas ao longo do tempo e o nível de emissões em relação ao Produto Interno Bruto (LA Rovere et al., 2005, p. 115).

Chega a ser intuitivo que a conveniência da utilização ou não de tais critérios para a definição de metas quantitativas de redução não seja intrínseca aos próprios métodos. Depende do objetivo que se busca alcançar e dos interesses que se quer defender.

Não havendo critério certo ou errado para a individualização das metas de redução de emissões entre os agentes regulados, tem-se que, no âmbito nacional, sob um prisma jurídico, a diferenciação das atividades econômicas deve estar baseada em critérios que façam sentido do ponto de vista da Constituição Federal e da PNMC.

Caso adotássemos a Proposta Brasileira para o compartilhamento das obrigações de reduções de emissões entre as atividades, a alocação de metas quantitativas entre as atividades econômicas deveria estar baseada na contribuição histórica de cada qual para a alteração da temperatura média do planeta. 
Sem adentrar no mérito da viabilidade prática da adoção desse critério ${ }^{58}$, a questão que colocaríamos para testar essa proposta sob a égide da Constituição Federal e da PNMC seria a seguinte: a responsabilidade histórica de cada atividade econômica para o aumento de temperatura média do planeta seria o critério mais adequado para conferir eficácia à proteção do clima mediante o tratamento diferenciado das atividades econômicas conforme suas emissões?

Em outro exemplo, caso considerássemos a proposta da CNI de definir os compromissos setoriais de acordo com a capacidade técnico-financeira de cada setor para reduzir emissões, sendo eles sempre voltados à eficiência da indústria, de forma a não impedir o aumento da produção, a questão seria: o critério da capacidade técnico-financeira de cada setor para reduzir emissões seria o mais adequado para conferir eficácia à proteção do clima mediante o tratamento diferenciado das atividades econômicas conforme suas emissões?

Em busca da efetivação dos dispositivos da Constituição Federal e da PNMC, formulamos as seguintes questões, a serem respondidas neste capítulo da dissertação: (i) segundo a doutrina jurídica e as experiências internacionais, quais são os critérios existentes para a definição de limites agregados de emissão, sejam eles globais ou setoriais, considerando-se a diferenciação das atividades econômicas de acordo com as suas respectivas responsabilidades quanto à origem das emissões e os efeitos ocasionados ao clima? (ii) segundo a doutrina jurídica e a experiência internacional, como alocar tais metas de redução entre as fontes de emissão?

Passamos a expor o resultado de nossa pesquisa à luz das questões acima formuladas.

\footnotetext{
${ }^{58}$ Para a concretização dessa proposta, seria necessário contar com dados históricos acerca das emissões de GEE por cada atividade econômica, coletados mediante a aplicação de metodologia uniforme que assegurasse a comparabilidade dos resultados obtidos.
} 


\subsection{Doutrina}

\subsubsection{Definição de limites agregados de emissão}

O surgimento dos mercados de carbono, em diferentes âmbitos geográficos, na primeira década do século XXI, provocou grande atenção sobre a aplicação do sistema capand-trade voltado à proteção do clima. Trata-se de mecanismo de controle de emissões de GEE, baseado na imposição de um limite global de emissões para determinado conjunto de fontes emissoras, conjugado com a flexibilização das metas individuais a partir do estabelecimento de "direitos transacionáveis entre os agentes ou a negociação em mercado aberto". (NUSDEO, 2012)

Como ensina Ana Maria de Oliveira Nusdeo: "Mercados de emissão são formados mediante a criação de títulos ou quotas representativos de licenças para emitir substâncias determinadas, alocadas entre as indústrias instaladas que podem ser negociadas entre aquelas que não as utilizam em totalidade e aquelas que necessitam ultrapassá-las. A fim de evitar-se um aumento ou mesmo a estabilização de emissões, os programas mais bem-sucedidos preveem uma redução progressiva das quotas em circulação no mercado”. (NUSDEO, 2012, p. 104)

Embora muito tenha sido escrito sobre a comercialização dos direitos transacionáveis decorrentes do cap-and-trade e as vantagens de sua aplicação, como o alcance do objetivo ambiental de forma economicamente eficiente ${ }^{59}$ (Kossoy e AmBrosi, 2010; KeOHANE, 2009; Ellerman, Joskow e Harrison JR., 2003; TietenberG, 2003), a definição de limites de emissões incita questões práticas e teóricas pouco abordadas pela literatura jurídica (MCALlister, 2009, p. 398).

\footnotetext{
${ }^{59}$ Esta afirmação justifica-se no fato de que as reduções serão realizadas nas fontes emissoras em que os custos para controle de emissões são mais baixos, podendo seus operadores vender as reduções excedentes para aqueles que operam fontes emissoras nas quais as reduções de emissões são mais custosas.
} 
É possível até mesmo dizer que se tomam por automáticos os benefícios dos mecanismos de comércio de emissões ${ }^{60}$, isto é, independentemente das decisões regulatórias que os amparam (DRIESEN, 2010, p. 5; DRIESEN, 2008, p. 61).

Segundo Driesen, a definição das metas regulatórias constitui um dos aspectos mais importantes no desenho de um sistema de comércio de emissões ou de programas regulatórios tradicionais $^{61}$, sendo decisiva para orientar os agentes regulados a cumprirem o objetivo pretendido pelo Agente Regulador.

Corroborando Driesen, McAllister defende que o sucesso ambiental dos programas de cap-and-trade está na definição das metas de redução de emissões. Segundo a autora, caso os limites de emissões não sejam restritivos o suficiente para atingir o objetivo ambiental, o programa não terá sido bem-sucedido mesmo que as fontes emissoras cumpram o teto de emissões (MCALLISTER, 2009, p. 396/397).

Para Winter o fato de os limites de programas de cap-and-trade serem definidos a partir de compromissos políticos e não serem orientados pela necessidade ecológica põe em xeque o próprio funcionamento desses mecanismos. Cita como exemplo o Protocolo de Quioto, cujas metas de redução foram definidas com base nos interesses de seus paísesmembros, assim como as metas da primeira e da segunda fase do Esquema Europeu de Comércio de Emissões, atualmente denominado Sistema Europeu de Comércio de Emissões (“EU-ETS”), que foram lastreadas nas negociações havidas no âmbito do Protocolo (WINTER, 2009, p. 16, 22).

\footnotetext{
${ }^{60}$ Os mercados de emissões tiveram sucesso em reduzir custos para alcançar reduções de emissões. Entre os exemplos mais bem-sucedidos, está o Programa contra Chuva Ácida implantado nos Estados Unidos pela Environmental Protection Agency nos anos 1990. A análise desse programa revelou que, de 1995-2007, os custos de redução das emissões de SO2 por meio do comércio de permissões de emissões foram $57 \%$ menores do que teriam sido os custos de redução em um programa de comando-e-controle (ELLERMAN, JOSKOW e HARRISON JR., 2003).

${ }^{61}$ Entendem-se aqui por programas regulatórios tradicionais aqueles que envolvem mecanismos de comando-econtrole das emissões atmosféricas. Para Lustosa, as características principais dos instrumentos de comando-econtrole são a imposição de padrões de emissões sobre a produção final ou sobre a utilização de um insumo básico; e a determinação da melhor tecnologia disponível para o abatimento da poluição e cumprimento do padrão de emissão (LUSTOSA, 2003, p. 136).
} 
Ainda não é possível extrair conclusões sobre os resultados ambientais do Protocolo de Quioto. Por sua vez, o estudo da primeira fase do EU-ETS, que abrangeu os anos de 2005 a 2007, leva à compreensão de que o estabelecimento de metas pouco ambiciosas pode significar a perda de oportunidade de promover significativos cortes de emissões e conferir incentivos para a inovação tecnológica (DRIESEN, 2008, p. 61).

Harrison Jr. e outros autores relatam que o estabelecimento de limites de emissões para a primeira fase do EU-ETS considerou dados limitados sobre níveis de emissões passados e presentes. Adicionalmente, o limite europeu total de emissões foi calculado a partir da soma das decisões individuais de cada Estado-membro sobre a quantidade a ser alocada para suas próprias indústrias, o que incentivou a oferta excessiva de permissões para as fontes emissoras domésticas, além de os Agentes Reguladores terem enfrentado dificuldades para analisar as emissões geradas no curso normal dos negócios (business as usual).

Segundo os autores, em 2006, quando os dados sobre as emissões verificadas em 2005 foram publicados, tornou-se claro que as emissões atuais eram significativamente menores do que o limite total imposto para todos os Estados-membros. O impacto da notícia no preço das permissões de emissões provocou de imediato sua queda para praticamente zero (HARRISON JR. ET AL., 2008, p. 10373).

Em sua obra Capping Carbon, Driesen explora os métodos existentes para a definição de metas de redução de emissões. Em sua opinião, as opções que se revelam ao Agente Regulador para o estabelecimento de limites de emissões em um mecanismo convencional de comando-e-controle são as mesmas enfrentadas na fixação dos tetos de emissões em mecanismo de cap-and-trade (DRIESEN, 2010, p. 20). Contudo, relembramos, de sua obra anterior, que a diferença existente entre eles é que o Agente Regulador sente-se mais confortável para estabelecer metas mais ambiciosas para os mecanismos de mercado do que para os mecanismos tradicionais de comando-e-controle. Isso porque os custos de cumprimento das metas regulatórias no âmbito de um mercado de direitos transacionáveis tendem a ser mais baixos (DRIESEN, 2008, p. 62). 
De fato, os instrumentos de comando-e-controle são impostos de forma pouco flexível, não considerando o local onde estão estabelecidas as fontes emissoras ou os custos individuais de cada agente regulado. Os instrumentos de mercado são mais flexíveis por incentivarem maior redução do nível de uso de um recurso ambiental por aqueles agentes regulados que enfrentam custos menores para alcançarem tal redução (SEROA DA MOTTA, 2000, p. 2).

Partindo dessa premissa, Driesen analisa três métodos dos quais pode se valer o Agente Regulador para limitar emissões, sendo posteriormente permitida ou não a comercialização de direitos transacionáveis entre os operadores das fontes emissoras: (i) o da efetividade (effectsbased); (ii) o da melhor tecnologia disponível (technology-based); e (iii) o do custo-benefício (cost-benefit based) (DRIESEN, 2010, p. 20/32).

O primeiro método não leva em conta os custos em que deverão incorrer os agentes regulados para o alcance da meta quantitativa tida como ideal para a proteção do bem ambiental. Esse método limita-se ao cálculo da quantidade de poluentes que o bem protegido suporta sem que o seu uso seja prejudicado.

Aqueles que defendem esse método geralmente argumentam que a preservação dos bens ambientais e da saúde pública é um objetivo absoluto que não permite flexibilização lastreada em fatores econômicos que pesam sobre os agentes regulados.

De outro lado, a fixação da meta ideal para a proteção do meio ambiente depende de cálculos complexos, baseados em dados empíricos. Muitas vezes, o Agente Regulador não tem em suas mãos as informações necessárias sobre as diversas variáveis que compõem o cenário natural em que deve atuar.

Junte-se a isso a dificuldade do Agente Regulador em impor de forma eficaz metas de redução de emissões que não levem em consideração a viabilidade técnica e econômica da adoção das medidas necessárias para seu alcance pelos agentes econômicos.

Seguindo o raciocínio de Driesen, poderíamos pensar em um exemplo da aplicação do método da efetividade à emissão de GEE: considerando que os países adotaram, por meio do 
Acordo de Copenhague ${ }^{62}$, a meta de manter o aumento de temperatura em até $2^{\circ}$ Celsius (em comparação com os níveis pré-industriais), o exercício que deveria ser feito, pelo método da efetividade, é estabelecer a quantidade máxima de concentração de GEE que a atmosfera pode suportar sem exceder ao objetivo fixado. A partir deste número, será possível mensurar o limite de emissões de GEE a ser imposto ao conjunto de países, em dado período de tempo.

Note-se que a lógica proposta prescinde da análise dos custos em que os países incorrerão para cumprir as metas estabelecidas ou mesmo do estudo do nível atual de emissões de cada país. Entretanto, para se chegar ao volume de emissões que a atmosfera suporta sem causar alterações no clima do planeta, é necessário lançar mão de modelagens sofisticadas, recursos humanos capacitados e investimentos em pesquisas.

Independentemente do custo e do tempo despendido no cálculo de metas pelo método da efetividade, a própria Convenção do Clima afirma que as políticas e medidas voltadas ao tratamento da mudança do clima devem ser custo-efetivas, de forma a promover benefícios globais ao menor custo possível. Assim, o método de estabelecimento de metas, no âmbito da Convenção deve conjugar a análise da efetividade das ações de proteção ambiental e dos custos para sua adoção, o que mais se aproximaria do terceiro método proposto por Driesen (custo-benefício), que será melhor explicado adiante.

A princípio, parece-nos que o estabelecimento de metas com base no critério da análise da efetividade promoveria idealmente o maior nível de proteção ambiental. Contudo, o conhecimento científico atual dos efeitos das emissões sobre o clima e a necessária sofisticação dos modelos matemáticos para estabelecer o limite máximo de emissões para garantir o uso da atmosfera sem comprometimento de sua função de regulação climática ainda dificultam a aplicação do critério da efetividade.

Mesmo que aplicado o critério da efetividade para estabelecer o limite agregado de emissões, a concretização da proteção do clima mediante o tratamento diferenciado das atividades econômicas conforme suas emissões demandará a alocação diferenciada do ônus entre os setores econômicos e as fontes emissoras individuais.

\footnotetext{
${ }^{62}$ Acordo assinado por grande parte dos países Parte da Convenção do Clima ao final da COP-15, realizada em Copenhague, no ano de 2009.
} 
Caso a meta global ou setorial fosse alocada de forma igualitária entre as fontes emissoras, as fontes com ótimo desempenho ambiental seriam obrigadas a contribuir para a redução das emissões no mesmo nível daquelas com desempenho ambiental limitado.

Nesse sentido, aqueles agentes que operassem as suas fontes emissoras com um controle ambiental menos rígido teriam uma maior margem para a redução do que aqueles que já aplicassem tecnologias de última geração para evitar emissões.

Teríamos, portanto, a recompensa dos agentes econômicos que mais emitiram GEE até a entrada em vigor da meta, em detrimento daqueles que já tivessem investido em melhorias ambientais em seus processos produtivos. Esses teriam que investir novamente em novas soluções ambientais para atingir níveis de emissões ainda mais ambiciosos.

É possível argumentar contrariamente no sentido de que a fixação de metas de redução com base na efetividade incentivaria a inovação tecnológica, vez que mesmo os agentes que empregassem a melhor tecnologia disponível no mercado deveriam reduzir suas emissões.

Essa seria uma vantagem da aplicação do método da efetividade em relação ao tratamento igual às fontes emissoras iguais e diferenciado às fontes emissoras diferentes, não encontrando amparo na ideia da proteção do clima mediante o tratamento diferenciado das atividades econômicas conforme suas emissões.

O segundo método apresentado por Driesen propõe que a definição de limites seja a consequência da análise das reduções que podem ser alcançadas com o emprego da melhor tecnologia disponível pelos agentes regulados em seus processos produtivos.

O método da análise da melhor tecnologia disponível é largamente utilizado na definição de padrões ambientais em programas de comando-e-controle (LUSTOSA, 2005, p. 136) e também em sistemas de comércio de emissões (DRIESEN, 2010, p. 30).

A legislação brasileira adota explicitamente a abordagem da melhor tecnologia disponível como critério de seleção de tecnologias a serem implementadas pelos agentes regulados para o alcance de certos padrões legais de emissões. 
O disposto no artigo $4^{\circ}$, da Resolução CONAMA n ${ }^{\circ} 316 / 2002$, por exemplo, determina que a adoção de sistemas de tratamento térmico de resíduos seja precedida de "um estudo de análise de alternativas tecnológicas que comprove que a escolha da tecnologia adotada está de acordo com a melhor técnica disponível”.

A própria Resolução CONAMA n ${ }^{\circ} 316 / 2002$ traz o conceito de melhores tecnologias disponíveis para o fim de aplicação de seus dispositivos, no artigo $2^{\circ}$, inciso II, a saber:

o estágio mais eficaz e avançado de desenvolvimento das diversas tecnologias de tratamento, beneficiamento e de disposição final de resíduos, bem como das suas atividades e métodos de operação, indicando a combinação prática destas técnicas que levem à produção de emissões em valores iguais ou inferiores aos fixados por esta Resolução, visando eliminar e, onde não seja viável, reduzir as emissões em geral, bem como os seus efeitos no meio ambiente como um todo.

Constata-se que a legislação ambiental brasileira já adota o método da análise da melhor tecnologia disponível para o alcance de reduções de emissões atmosféricas, no caso, advindas do tratamento térmico de resíduos sólidos (dentre eles, material particulado, monóxido de carbono, óxidos de enxofre e dioxinas e furanos).

A análise da melhor tecnologia disponível, a princípio, é compatível com a ideia de proteção do clima mediante o tratamento diferenciado das atividades econômicas conforme suas emissões. O método permite que se analise qual é o nível de emissões que pode ser alcançado pela operação das fontes emissoras de determinado setor econômico com a utilização da melhor tecnologia disponível.

Uma vez imposto tal nível como meta setorial, os operadores das fontes emissoras que já empregam a melhor tecnologia disponível para reduzir as emissões de Gases de Efeito Estufa não seriam impactados pelo programa ambiental. Note que, nesse caso, tais operadores seriam recompensados pelos investimentos que já realizaram em seus processos produtivos para alcançarem o menor nível de emissões possível com a adoção da melhor tecnologia disponível. 
De outro lado, os operadores de fontes que emitissem mais do que o nível alcançável pela adoção da melhor tecnologia disponível seriam impactados pela meta setorial. Nesse cenário, os operadores deveriam investir em melhorias em seu processo produtivo para reduzir emissões.

Por fim, aqueles operadores de fontes emissoras que tivessem um desempenho ambiental extraordinário, ao combinar a adoção da melhor tecnologia disponível com alguma solução técnica peculiar de seu processo produtivo não acessível aos demais agentes do mercado, deveriam ser recompensados pela legislação ambiental por meio de incentivos econômicos, como a possibilidade de comercializar o excedente de suas reduções de emissões.

Parece-nos, portanto, que o critério de fixação de meta setorial que leva em conta a análise da melhor tecnologia disponível permite o tratamento diferenciado das atividades econômicas segundo suas emissões atuais de GEE.

A crítica mais recorrente com relação à análise da melhor tecnologia disponível para o estabelecimento de metas é que o Agente Regulador necessita de dados sobre as tecnologias existentes no mercado e dos seus custos relacionados, dependendo de informações a serem disponibilizadas pela iniciativa privada (UNEP, 2004, p. 20). Parece-nos, ainda, que o Agente Regulador está sujeito ao lobby e à captura por agentes econômicos desenvolvedores de tecnologias, que poderiam se beneficiar do estabelecimento de metas ambiciosas que somente poderiam ser alcançadas com o uso de suas inovações.

No que diz respeito ao terceiro método trazido por Driesen, o da análise do custobenefício, a meta quantitativa é tida como o ponto ótimo entre o necessário investimento de recursos financeiros para a suficiente proteção do bem ambiental.

Nesse caso, o Agente Regulador também analisa os custos envolvidos no alcance das metas que serão definidas. No entanto, diferentemente do método anterior, busca estabelecer uma relação de custo-benefício entre as medidas que deverão ser tomadas pelos agentes regulados e o objetivo regulatório pretendido. 
Segundo Cánepa, na análise de custo-benefício, há uma dupla valoração da medida ambiental. Isto é, há a valoração econômica dos custos para a adoção da medida e a valoração dos benefícios de sua aplicação. Em termos econômicos, o custo marginal de abatimento deve igualar-se ao benefício marginal de abatimento (CÁNEPA, 2003).

Aqui, a dificuldade da análise dos custos incorridos pelo agente regulado para alcançar certo grau de proteção ambiental soma-se à dificuldade de valorar os benefícios ambientais resultantes da aplicação de tais recursos financeiros.

Como mencionado anteriormente, a Convenção do Clima dispõe, entre os seus princípios, que as "políticas e medidas adotadas para enfrentar a mudança do clima devem ser eficazes em função dos custos (cost-effectives), de modo a assegurar benefícios mundiais ao menor custo possível”. Tal dispositivo impulsiona suas Partes a realizarem um balanço dos investimentos necessários para a adoção das ações voltadas ao alcance do objetivo da Convenção e, dentro das possibilidades existentes, adotar aquelas menos dispendiosas que proporcionem benefícios globais.

Nesse sentido, o artigo $4^{\circ}$, parágrafo $2^{\circ}$, da Convenção, que dispõe sobre as obrigações das Partes países desenvolvidos, possibilita que as políticas de reduções de emissões sejam desenvolvidas conjuntamente com outras Partes, podendo, inclusive, auxiliar essas outras Partes a contribuírem para que se alcance o objetivo da Convenção. Aqui reside o fundamento dos mecanismos de mercado instituídos posteriormente pelo Protocolo de Quioto - o MDL, a Implementação Conjunta e o Comércio de Emissões.

A Convenção, portanto, sugere o emprego do método do custo-benefício para o alcance dos compromissos de emissões impostos aos países de forma global, podendo esses valeremse das reduções de emissões realizadas com um menor investimento no território de outros países desenvolvidos (Implementação Conjunta e Comércio de Emissões) ou de países em desenvolvimento (MDL). 
Há, contudo, controvérsias quanto ao fato de as reduções de emissões movidas pela busca do menor custo possível estarem ou não alinhadas com o objetivo da promoção do desenvolvimento sustentável, também perseguido pela Convenção do Clima.

Driesen, por exemplo, argumenta que os sistemas de comércio de emissões não são tão eficazes no incentivo à busca por novas formas de energia quanto as políticas orientadas a reduções de emissões nas próprias fontes emissoras. Essa ideia está fundamentada no fato de que as reduções com baixo custo estão associadas a soluções que não agregam valores caros ao desenvolvimento sustentável como a inovação tecnológica e são despidas de externalidades positivas (DRIESEN, 2008, p. 57).

Ainda nesse sentido, há críticas de que as atividades de projetos de MDL não atendem ao objetivo de contribuir para o desenvolvimento sustentável nos países que as hospedam. Para Streck, as críticas em torno do MDL podem ser classificadas em quatro ordens: (i) há falha no balanço entre os aspectos social, econômico e ambiental que devem envolver o projeto de MDL; (ii) a integridade ambiental do projeto muitas vezes fica comprometida pela ausência de comprovação das reduções reais e adicionais de emissões em comparação ao cenário sem o projeto; (iii) o ciclo de aprovação do projeto é muitas vezes ineficiente e não transmite credibilidade; e (iv) o MDL não logrou promover reduções de emissões em larga escala e incentivar suficientemente os países em desenvolvimento a seguirem um caminho de desenvolvimento de baixa emissão de carbono (STRECK, 2009, p. 93/94).

Ainda que o método do custo-benefício tenha sido empregado pelos países Partes da Convenção do Clima para o alcance das metas impostas aos países elencados no Anexo I do Protocolo de Quioto, este método não foi utilizado para a fixação das metas em si. A definição das metas do primeiro período de compromisso do protocolo baseou-se em critérios puramente políticos e diplomáticos.

Existem estudos econômicos que propõem o cruzamento dos níveis de redução de emissões que devem ser perseguidos pela humanidade para se evitar catástrofes de origem climática com as estimativas dos recursos financeiros necessários para seu alcance. 
Um dos estudos que ficou mais conhecido pela análise do custo-benefício das ações humanas a serem adotadas contra o aquecimento global é o Stern Review on the Economics of Climate Change (STERN, 2006) ${ }^{63}$.

O "Relatório Stern", como ficou conhecido no Brasil, provocou grande impacto nos atores da economia global por ter traduzido em cifras os potenciais prejuízos do aquecimento global previstos pelos cientistas do IPCC. Segundo o estudo, caso as medidas contra o aquecimento global fossem tomadas imediatamente, seria possível estabilizar as concentrações de GEE na atmosfera, a níveis não prejudiciais à vida do planeta, a um custo razoável para os países.

Para se evitar maiores prejuízos futuros, assumindo a estabilização do clima com concentração de 550 ppm de $\mathrm{CO}_{2}$ e na atmosfera em 2050, Stern calculou o custo de $1 \%$ do PIB global até esse ano. Segundo Stern a aplicação de 1\% do PIB mundial em medidas preventivas e mitigatórias não teria grande impacto no mercado global e na competitividade dos países, sendo inclusive condizente com as aspirações de crescimento econômico dos países (STERN, 2006, p. 13).

No âmbito nacional, devemos nos questionar se a fixação de metas a partir da análise de seu custo-benefício estaria amparada pela ideia da proteção do clima mediante o tratamento diferenciado das atividades econômicas conforme suas emissões. Isto é, se a análise dos custos de redução de uma unidade de emissão em determinado setor econômico implicaria seu tratamento diferenciado em prol da proteção do clima.

A análise do custo-benefício da redução de emissões por um setor econômico permitiria concluir em quais atividades econômicas o mesmo valor de investimento induziria uma maior proteção ao clima.

\footnotetext{
${ }^{63}$ Como comentado anteriormente, estudo organizado pelo Banco Mundial, denominado Estudo de Baixo Carbono para o Brasil (GoUVELLO, 2010), analisou as reduções de emissões que podem ser alcançadas a partir da adoção das medidas de mitigação identificadas e quantifica os investimentos necessários para tanto, permitindo uma análise do custo-benefício de cada medida proposta. Vide página 32 desta dissertação.
} 
Essa análise faz sentido do ponto de vista macroeconômico, na medida em que seria possível reduzir os custos econômicos totais realizados no País para o alcance do compromisso nacional voluntário.

Nesse caso, haveria a diferenciação de atividades econômicas não conforme suas emissões, mas conforme o custo de redução de suas emissões. Nota-se que a proposta da CNI para o estabelecimento de metas setoriais com base na capacidade técnico-financeira do setor para reduzir emissões identifica-se com essa ideia (vide página 29).

Para nos auxiliar a aclarar esta questão, McAllister analisa como os limites de emissões foram definidos em quatro mercados de emissões atmosféricas em que houve comprovada oferta excessiva de permissões de emissões, prejudicando o alcance do objetivo ambiental dos programas $^{64}$. Isto é, as permissões para as fontes reguladas liberarem gases na atmosfera foram distribuídas em quantidade maior do que as necessárias para cobrir as emissões geradas no curso normal dos negócios (business as usual) (MCALLISTER, 2009, p. 410).

A autora conclui que o êxito ambiental nos programas estudados é alcançado quando os limites de emissões impostos são suficientemente restritivos para motivar reduções de emissões na mesma quantidade daquelas que seriam obtidas pela exigência do uso de tecnologias de controle de emissões viáveis do ponto de vista técnico e econômico. A autora denomina essa abordagem de princípio da viabilidade (MCAllister, 2009, p. 426).

O princípio da viabilidade requer que o Agente Regulador identifique as tecnologias disponíveis para reduzir as emissões, avalie em que medida tais reduções podem ser realizadas com o uso dessas tecnologias e estime os custos associados à implementação das tecnologias disponíveis.

\footnotetext{
${ }^{64}$ Os programas analisados por McAllister foram United States Acid Rain Program (ARP), Los Angeles Regional Clean Air Markets (RECLAIM), Chicago Emissions Reduction Market System (ERMS) e a Fase 1 do EU-ETS.
} 
Segundo a autora, este exercício foi realizado pela Agência de Proteção Ambiental dos Estados Unidos para fixar os padrões legais do Clean Air Act. Como resultado, chegou-se nos critérios do "menor índice alcançável de emissões" ou da "melhor tecnologia de controle disponível" para o estabelecimento de limites de emissões por fonte.

A autora conclui que, de acordo com o princípio da viabilidade, "o nível correto de rigor (stringency) do programa é o nível que faz com que os poluidores reduzam sua poluição tanto quanto possível sem causar uma crise econômica na indústria” (MCALLISTER, 2009, p. 426-428).

Amparados pelas conclusões de McAllister e à luz da ideia da proteção do clima mediante tratamento diferenciado das atividades econômicas conforme suas emissões, parecenos que a análise dos custos de redução de emissões em determinado setor deva ser considerada na fixação da meta setorial, desde que aliada à análise da adoção da melhor tecnologia disponível pelos operadores das fontes emissoras.

Vale dizer que acreditamos que a diferenciação de tratamento dos setores econômicos quanto à análise do custo de redução de emissões faz sentido do ponto de vista constitucional somente se este fator estiver atrelado à atual utilização da melhor tecnologia disponível no mercado para a operação de determinada fonte de emissão.

Nesse caso, como concluído em relação ao segundo método de fixação de metas, estarse-á recompensando o agente econômico que tem buscado desenvolver sua atividade com o menor impacto possível ao clima e já realizou investimentos que o colocaram como referência pelo desempenho ambiental em comparação a outros agentes do setor.

Por outro lado, caso a atividade econômica seja intensiva em emissões de GEE, mas haja a possibilidade de adoção de tecnologias existentes a um custo elevado, parece-nos que não há amparo constitucional para se impor um maior ônus de mitigação de emissões a outra atividade econômica em que a redução tem um custo menor, para se privilegiar a primeira atividade econômica em detrimento da segunda. Do contrário, o tratamento diferenciado das atividades econômicas estaria sendo empregado para onerar um agente em prejuízo de outro, numa situação em que ambos teriam capacidade técnica para reduzir emissões. 
Alerta-se que isso não significa que a fixação de meta de reduções de emissões não deva levar em conta a exposição do setor econômico à concorrência internacional. Como se verá mais adiante, caso o Agente Regulador não observe essa variável para o estabelecimento de metas de reduções, corre o risco de ocasionar o efeito deletério da fuga de carbono.

\subsubsection{Individualização dos limites de emissões entre as fontes emissoras}

Definidos os limites agregados de emissões, sejam elas globais ou setoriais, no âmbito de programas cap-and-trade ou de comando-e-controle, é necessário alocá-los entre as fontes emissoras, de forma que cada qual contribua com a redução das emissões de GEE.

Quando o Agente Regulador permite a realização de transferências dos direitos de emissão entre os agentes regulados, os limites agregados são divididos em permissões, as quais são distribuídas entre as fontes emissoras, de forma gratuita ou onerosa. Nos programas em que tal transferência não é prevista, é preciso decidir se todas as fontes emissoras deverão reduzir as emissões em quantidades iguais ou se haverá critério de diferenciação dos limites de emissões entre as fontes emissoras.

Tanto a primeira quanto a segunda ideia são tratadas nesta dissertação como processo de individualização das metas de redução de emissões.

A forma pela qual as permissões são distribuídas em um sistema cap-and-trade ou a definição das metas individuais em um programa de comando-e-controle não é tão importante, do ponto de vista da integridade ambiental do programa, quanto a definição dos limites agregados de emissões.

Mesmo que a individualização das metas de redução de emissões entre os agentes

regulados não afete o resultado ambiental do programa, pode suscitar tentação do Agente Regulador em estabelecer limites individuais bastante controversos, provocando conflitos entre concorrentes (COMISSÃO EUROPEIA, 2000, p. 18).

Esse problema pode ocorrer porque a alocação das permissões ou a definição das metas individuais para cada fonte emissora é muitas vezes utilizada como um instrumento político para calibrar diversos interesses econômicos. Segundo Keohane, o fato de a alocação ter 
natureza política não é negativo, pois auxilia na efetivação do objetivo ambiental do programa, vez que acomoda diferentes realidades dos agentes regulados (KEOHANE, 2009, p. 82).

Para que a etapa da individualização das metas de redução ocorra de forma a não provocar conflitos entre os agentes regulados e funcione como instrumento de viabilização do objetivo ambiental do programa (assegurado pela definição adequada do limite agregado), deve haver critérios consistentes que façam sentido do ponto de vista normativo, técnico e econômico.

A perspectiva normativa da individualização de metas entre os agentes regulados, a qual nos interessa na presente dissertação, deve estar lastreada no ordenamento jurídico vigente no âmbito territorial do programa de redução de emissões.

Como vimos no capítulo 2 desta dissertação, o arcabouço normativo brasileiro que deve orientar a redução de emissões pelo agente regulado determina que as fontes emissoras sejam tratadas de forma a respeitar a responsabilidade de cada qual pelas respectivas emissões. Ou seja, deve-se assegurar o tratamento diferenciado das atividades econômicas conforme suas emissões.

Essa perspectiva normativa serviu-nos de premissa para a avaliação dos métodos de fixação de limites agregados de emissão e servirá de ponto de partida neste subcapítulo para a análise do processo de individualização das metas entre as fontes de emissão.

Partimos da hipótese de que a alocação igualitária das metas individuais de redução entre os agentes regulados não reconheceria a responsabilidade de cada qual por suas respectivas emissões, como determina nosso ordenamento jurídico.

O que queremos dizer com alocação igualitária de metas individuais é a divisão do limite agregado de emissões pelo número de fontes emissoras existentes no mercado. Dessa forma, supondo-se que a meta de redução setorial fosse de $10 \%$ (dez por cento) da projeção feita para o setor em 2020; assumindo-se, portanto, que 90\% das emissões consistissem em 20 
gigatoneladas de $\mathrm{CO}_{2}$ eq e houvesse 100 fontes de emissões abrangidas pelo setor no País; terse-ia limite máximo de emissão de 200 toneladas de $\mathrm{CO}_{2}$ eq por fonte emissora em $2020^{65}$.

Esse critério de divisão poderia provocar questionamentos em relação à distribuição de metas iguais de redução por fonte emissora, independentemente do número de unidades geradas por processo produtivo.

Não é difícil imaginar que os processos produtivos que gerassem mais unidades de produção com a mesma quantidade de emissões seriam prejudicados em relação aos processos produtivos que gerassem menos unidades.

Imaginemos, de forma hipotética, que o primeiro grupo produzisse, no ano de início do programa, 2000 unidades de produção e emitisse 400 toneladas de $\mathrm{CO}_{2}$ eq. Já o segundo grupo, produzisse 1000 unidades de produção e emitisse as mesmas 400 toneladas de $\mathrm{CO}_{2} \mathrm{eq}$.

Para o primeiro grupo cumprir o limite de 200 toneladas de $\mathrm{CO}_{2}$, considerando a emissão atual de 0,2 toneladas por unidade de produto, teria de reduzir o índice de emissão por unidade de produto ou reduzir suas unidades de produção. Dessa forma, deveria investir em alteração em seu processo produtivo para passar a emitir 200 toneladas de $\mathrm{CO}_{2}$, seja reduzindo o índice de emissões por produto para 0,1, seja limitando sua produção em 1000 unidades.

O segundo grupo, que emitia inicialmente 0,4 toneladas de $\mathrm{CO}_{2}$ eq por unidade de produção, poderia optar por reduzir suas emissões para 400 toneladas de $\mathrm{CO}_{2}$ mediante a aplicação da mesma tecnologia utilizada pelo primeiro grupo de empresas, de forma a chegar a um índice de 0,2 toneladas por produto, ou diminuir a quantidade de unidades de produção para 500.

É possível, contudo, que o primeiro grupo já produzisse suas unidades de produção com a máxima eficiência e, portanto, não houvesse outra opção para cumprir o seu limite individual, senão reduzir a sua produção. Neste caso, a individualização do limite de emissões estaria punindo a fonte emissora eficiente, que já havia investido no emprego da melhor tecnologia disponível, em detrimento da ineficiente.

\footnotetext{
65 Note-se que, para efeitos de nosso raciocínio, ignoramos neste exercício a entrada de novos agentes econômicos no mercado.
} 
Se admitíssemos a conversão do limite absoluto de emissões para um limite de intensidade de emissões por unidade de produtos, a distribuição de emissões entre cada fonte emissora levaria em conta o número de unidades produzidas associadas a cada fonte de emissão.

Neste caso, teríamos que cada fonte emissora teria direito a emitir até um limite "Y" de emissões por unidade produzida. Definido o índice $\mathrm{Y}$ de emissões por unidade, esse poderia ser multiplicado pela projeção de produção de cada fonte emissora, sendo este o total de emissões que cada fonte emissora poderia emitir em certo período de tempo (BUCHNER, CARraro e Ellerman, 2006, p. 10).

O Agente Regulador deveria, portanto, definir o limite Y de emissões de GEE adequado para cada unidade produzida no Plano Setorial. A definição de Y poderia representar o índice de emissões de certa fonte em dado período histórico (processo denominado pela doutrina de grandfathering) ou um índice de emissões baseado em referência comum para o setor (benchmarking setorial).

O primeiro método calcula a meta individual com base nas emissões recentes de certa fonte emissora (TIETENBERG, 2003, p. 410-411).

Assim, se a fonte emissora libera 4 toneladas de emissões por unidade produzida, considerando o limite de emissões de $90 \%$ de suas emissões atuais até 2020 , teria de reduzir suas emissões para 3,6 toneladas de $\mathrm{CO}_{2}$ por unidade produzida em 2020 (mantida a sua produção atual).

Contudo, se a fonte emissora fosse mais eficiente e produzisse uma unidade a partir da emissão de 0,5 toneladas de $\mathrm{CO}_{2}$ eq, o mesmo limite de $90 \%$ de suas emissões atuais em 2020 significaria ter de reduzir suas emissões para 0,45 toneladas de $\mathrm{CO}_{2} \mathrm{eq}$ por unidade produzida.

Note que as fontes com maiores emissões atuais ou em dado período histórico teriam maiores margens para progredir que aquelas fontes que já atingiram as reduções máximas alcançáveis (QUIRION, 2009, p. 578). 
Assim, conclui-se que o grandfathering, ao invés de beneficiar as atividades econômicas mais eficientes, promoveria as atividades econômicas com elevadas emissões em relação ao índice de referência de seu setor. As fontes menos eficientes teriam o direito de continuar produzindo com emissões superiores a outras fontes emissoras mais eficientes (no exemplo dado, emitiria 8 vezes mais) em detrimento do meio ambiente.

Por outro lado, as fontes que já atingiram as reduções máximas alcançáveis ao longo de sua história recente, por meio da realização de investimentos em mecanismos de controle de emissões, seriam prejudicadas pois deveriam reduzir suas emissões ainda mais. Caso não fosse viável aplicar tecnologias disponíveis no mercado para reduzir além do índice máximo alcançável, não lhes restaria outra opção que reduzir suas unidades produtivas.

Por meio de um segundo método, Y também poderia ser definido por meio da adoção de um índice de eficiência de emissões conhecido para o setor (BUCHNER, CARRARO e ELLERMAN, 2006, p. 10) ou pela construção de um índice com base na aplicação da análise da melhor tecnologia disponível para o alcance da meta, como define Driesen.

Sendo aplicado esse segundo método de individualização de emissões, o grupo de fontes emissoras mais eficientes poderia manter seu nível de emissões por unidade de produção caso este nível fosse coincidente com o limite Y proposto pelo Agente Regulador.

A realização do cálculo de emissões por unidade com base em um índice de referência no setor (aqui referido como benchmark setorial ${ }^{66}$ ) favorece as atividades econômicas que tenham baixas emissões por unidade de produção se comparadas ao restante do setor.

\footnotetext{
66 "Benchmarking is an updating approach based on specific engineering or technological criteria. It aims to encourage best-practice emissions rates for given entities. Benchmarking can be used within an output-based allocation approach to address differences among industries, technologies or fuels. Under the benchmarking approach, the regulator establishes a baseline emissions rate for an industry (e.g., cement) or process (e.g., coalfired electricity generation) and awards allowances to all facilities in that industry according to the "benchmark" GHG content of their output". (EAAC, 2010, p. 20)
} 
De fato, caso a fonte emissora já produza suas unidades com o menor índice de emissões alcançável (equivalente a Y), não precisaria reduzir suas emissões para cumprir com a meta individual, a menos que fosse incentivada a fazê-lo com a implementação de um sistema de comércio de reduções de emissões excedentes, como já foi aventado nesta dissertação. Neste caso, toda a redução acima do necessário para o estrito cumprimento da meta individual seria valorizada com a perspectiva de sua venda no mercado como um "direito transacionável” (NUSDEO, 2012).

É claro que o Agente Regulador deverá analisar se a aplicação do índice para todas as fontes emissoras do setor promoveria o alcance do limite agregado, que garantirá o resultado ambiental do programa. Caso contrário, mesmo que todas as fontes emissoras cumpram o índice individual de emissões propostos, não será suficiente para o alcance do objetivo ambiental do programa.

O estabelecimento do índice individual também deverá levar em conta o crescimento da produção pelos agentes regulados e a entrada de novos agentes regulados, sob pena de a multiplicação das unidades produzidas, mesmo que de forma eficiente, provocar o descumprimento do limite agregado de emissões.

Outra questão que deverá ser considerada pelo Agente Regulador quando da individualização dos limites de emissões é a sensibilidade da atividade econômica à fuga de carbono, que pode ocorrer quando o agente regulado sofre concorrência de outros agentes econômicos não submetidos ao mesmo programa ambiental.

A definição do índice de emissões por unidade produzida deverá levar em conta o máximo de reduções alcançáveis pelo agente regulado sem que este deixe de produzir no ambiente regulado e o seu mercado relevante passe a consumir o mesmo produto elaborado por processo de produção que gere emissões mais elevadas que o agente regulado costumava emitir.

Caso o consumidor passe a adquirir o produto de concorrente não estabelecido em território coberto pelo programa ambiental, a emissão dos GEE deixará de ser realizada no ambiente regulado e passará a ocorrer em outro local do globo. Considerando-se que as emissões realizadas em qualquer ponto do planeta geram o mesmo efeito para o clima, deve 
haver um tratamento diferenciado pelo Agente Regulador para aquelas atividades econômicas que sofrem o risco da chamada fuga de carbono (HARRISON JR. et al., 2008, p. 10.379).

\subsection{Experiências regionais e locais}

Inicialmente, expusemos o arcabouço normativo brasileiro que deverá orientar o estabelecimento de metas nos Planos Setoriais previstos na PNMC. Em seguida, investigamos quais são os métodos identificados pela doutrina para a definição de metas de reduções, agregadas e individuais, analisando-as tendo como pano de fundo a ideia da proteção do clima mediante o tratamento diferenciado das atividades econômicas.

Passa-se, neste momento, à abordagem dos critérios utilizados pelos mecanismos de mercado de emissões já implantados na União Europeia e em fase de implantação na Califórnia para a fixação de limite agregado de emissões e alocação de metas de redução de emissões entre as fontes individuais de acordo com as suas respectivas responsabilidades quanto à origem das emissões e os efeitos ocasionados ao clima.

Com isso, pretende-se reunir as ferramentas doutrinárias e empíricas necessárias para estudar os Planos Setoriais publicados até o momento da conclusão desta dissertação, com o foco na efetivação dos dispositivos normativos da Constituição Federal e da PNMC.

\subsubsection{União Europeia}

A União Europeia comprometeu-se a reduzir $8 \%$ de suas emissões conjuntas havidas em 1990, no primeiro período de compromisso do Protocolo de Quioto, compreendido entre 2008 e 2012. Para auxiliar os seus países-membros a atingirem suas metas individuais de forma economicamente eficiente, a Diretiva Europeia $n^{\circ}$ 2003/87/EC instituiu EU-ETS. Tratase de mecanismo que combina o estabelecimento de limites de emissões por fontes emissoras e a possibilidade de comércio de reduções de emissões excedentes entre elas (cap-and-trade).

Em operação desde janeiro de 2005, o EU-ETS compreendia, inicialmente, os setores de energia elétrica, refinarias de petróleo, fornos de coque, produção de metais e aço, produção de cimento, vidro, cerâmica e papel e celulose. As fontes emissoras abrangidas por 
tais setores representavam cerca de metade das emissões europeias de $\mathrm{CO}_{2}$, localizadas nos 27 Estados-membros da União Europeia, além de Noruega, Islândia e Liechtenstein ${ }^{67}$.

A Diretiva Europeia $n^{\circ} 2004 / 101 / E C$ interligou o EU-ETS aos mecanismos de flexibilização do Protocolo de Quioto, permitindo que os Estados-membros utilizem Reduções Certificadas de Emissões (RCE) do MDL ou Unidades de Redução de Emissões (URE), advindas da Implementação Conjunta, para o cumprimento de até $15 \%$ de seus compromissos de redução ${ }^{68}$.

Durante a Fase I (2005-2007) e a Fase II (2008-2012) do EU-ETS, o limite agregado de emissões deveria ser calculado pelas Autoridades Competentes dos Estados-membros e dividido em permissões a serem distribuídas entre os setores econômicos e as fontes emissoras individuais, de acordo com os Planos Nacionais de Alocação (National Allocation Plans "NAP"). Os NAPs deveriam ser aprovados pela Comissão Europeia antes de serem executados pelos Estados-membros.

Calculadas as quantidades de permissões alocadas para cada setor e fonte emissora, é preciso que se defina a forma com que serão distribuídas. Durante a Fase I do EU-ETS, as permissões foram distribuídas gratuitamente, exceto 5\% delas, que foram leiloadas. Na Fase II, foi permitida a alienação onerosa de $10 \%$ das permissões.

Os NAPs descrevem a estratégia adotada pelo Estado-membro para atingir sua meta, considerando as linhas de ação a serem adotadas com relação aos setores não cobertos pelo EU-ETS (como transporte, agricultura, etc.) e a quantidade estimada de RCE e URE a serem computadas. A elaboração dos NAPs deveria se pautar pelos critérios listados no Anexo III da Diretiva Europeia n²003/87/EC, a saber: (1) Compromissos de Quioto; (2) Avaliação do desenvolvimento das emissões; (3) Potencial para reduzir emissões; (4) Consistência com outras legislações; (5) Não-discriminação entre companhias e setores; (6) Agentes ingressantes; (7) Reduções antecipadas (early actions); (8) Tecnologia limpa; (9) Envolvimento do público; (10) Lista das fontes emissoras; e (11) Competição de fontes emissoras localizadas fora da União Europeia.

\footnotetext{
${ }^{67}$ Dados disponíveis na página de internet <http://ec.europa.eu/clima/policies/ets/index_en.htm>, acessada em 24 de abril de 2011.

${ }^{68}$ Com exceção das reduções promovidas por atividades nucleares ou ligadas à mudança de uso da terra.
} 
A Comissão Europeia publicou, em 07 de janeiro de 2004, comunicação aos Estadosmembros em que esclarece o conteúdo de cada critério e como deverão ser utilizados nos NAPs (COMISSÃo EUROPEIA, 2004) ${ }^{69}$.

Os critérios 3, 7, 8 e 11 acima dizem respeito à consideração das características peculiares dos setores e fontes emissoras individuais como fator para alocação das permissões de emissões. Os critérios 7, 8 e 11 não são de aplicação obrigatória, enquanto o critério 3 é de aplicação obrigatória para a definição da quantidade agregada de permissões e opcional para a alocação de permissões entre as fontes emissoras individuais.

Com relação ao nível em que serão considerados tais critérios, os critérios 3 e 11 são aplicáveis na alocação das permissões entre as fontes emissoras individuais. Já os critérios 7 e 8 são aplicáveis na distribuição das permissões entre as fontes emissoras individuais. A seguir, tais critérios serão analisados de forma pormenorizada, com base na leitura de referida comunicação da Comissão Europeia.

(i) Potencial para reduzir emissões (3)

O potencial tecnológico ou econômico de uma atividade para reduzir emissões é listado no Anexo III da Diretiva Europeia 2003/87/EC como fator que pode ser levado em consideração pela Autoridade Nacional para alocação das permissões de emissões entre os setores ou fontes emissoras individuais.

A aplicação desse fator visa a alocação das permissões de forma que a meta de redução de emissões seja realizada com o melhor custo-benefício para o país como um todo. Esse critério possibilita que os Estados-membros utilizem benchmarking, entendidos aqui como padrões de referência consistentes na média das emissões liberadas por produto ou as reduções de emissões possíveis de serem alcançadas em seu processo de produção.

\footnotetext{
${ }^{69}$ Communication from the commission on guidance to assist Member States in the implementation of the criteria listed in Annex III to Directive 2003/87/EC establishing a scheme for greenhouse gas emission allowance trading within the Community and amending Council Directive 96/61/EC, and on the circumstances under which force majeure is demonstrated. Disponível em:

<http://europa.eu/legislation_summaries/energy/european_energy_policy/128012_en.htm>.
} 
A análise dos benchmarks possibilita que se exija maior corte de emissões daqueles setores que tenham uma média de emissões mais alta e que comporte redução de emissões a baixo custo se comparada a outros setores. Note-se que esse critério especifica benchmark por produto, o que indica que uma mesma atividade pode cobrir diversos produtos, a serem tratados de forma diferenciada pelo Estado-membro.

Para a adoção do critério 3 na definição da quantidade total de permissões, o Estadomembro deverá comparar o potencial econômico ou tecnológico para redução de emissões entre os setores ou fontes emissoras individuais cobertas e não cobertas pelo NAP. Para a alocação de permissões, poderá diferenciar os setores ou atividades econômicas cobertas pelo NAP, de acordo com o potencial econômico ou tecnológico para redução de emissões.

Nos termos utilizados na comunicação,

o potencial econômico das atividades para reduzir emissões de $\mathrm{CO}_{2}$ deve estar baseado em uma avaliação dos custos de abatimento por tonelada de $\mathrm{CO}_{2}$ equivalente, e não na viabilidade econômica das companhias ou instalações compreendidas pela atividade ou atividades consideradas. (COMISSÃO EUROPEIA, 2004, p. 10) ${ }^{70}$

Vale ainda citar a definição constante na comunicação para melhor técnica disponível, que poderá ser utilizada pelo Estado-membro para avaliar o potencial tecnológico da atividade ou do setor para reduzir emissões: "a melhor técnica disponível é definida como a técnica que é a mais efetiva em atingir um alto nível geral de proteção do meio ambiente como um todo" (COMISSÃo EUROPEIA, 2004, p. 10) ${ }^{71}$.

\footnotetext{
${ }^{70}$ A definição é extraída pela Comissão Europeia da diretiva 96/61/EC relativa à prevenção e controle de poluição integrada. Trata-se de tradução livre do original: "The economic potential of activities to reduce CO2 emissions should be based on an assessment of abatement costs per tonne of CO2equivalent, and not on the economic viability of individual companies or installations belonging to the activity or activities concerned".

${ }^{71}$ Tradução livre do original: A "best" available technique is defined as a technique, which is "most effective in achieving a high general level of protection of the environment as a whole".
} 
(ii) Reduções antecipadas (7)

O Estado-membro também poderá considerar as reduções antecipadas de emissões realizadas pelas fontes emissoras no momento de alocação das permissões de emissões entre elas. A ideia subjacente a esse critério é a de que, por razão de justiça, as fontes que tenham reduzido seus índices de emissão antes que a legislação as obrigasse ou, ainda, tenham emitido abaixo do que lhe foi exigido, não sofram desvantagem em relação aos seus concorrentes.

Em outras palavras, a aplicação do critério resulta na alocação de menos permissões de emissões para as fontes que emitem mais segundo um padrão de referência a ser adotado pelo Estado-membro.

Note-se que a diretiva europeia não trouxe definição de reduções antecipadas, o que significa dizer que cada Estado-membro tem liberdade para definir o conceito para fins da alocação de permissões entre as fontes emissoras em seu território, respeitando os demais critérios enumerados no Anexo III e as outras normas europeias de política de mudança do clima.

De acordo com a comunicação, há três formas para acomodar as reduções antecipadas: (i) estabelecer um período-base anterior; (ii) realizar duas rodadas de alocação no nível das fontes emissoras e (iii) utilizar benchmarks.

Pela primeira forma, o Estado-membro poderia realizar a alocação de permissões com base nas emissões históricas em dado período de tempo anterior à realização de investimentos para reduzir emissões, desde que esses não tenham ocorrido em função de obrigações legais.

$\mathrm{Na}$ segunda abordagem, o Estado-membro deve reservar algumas permissões no momento da definição da quantidade total a ser distribuída no mercado. Após uma primeira alocação às fontes emissoras, aqueles operadores que tivessem realizado ações elegíveis como reduções antecipadas deveriam pleitear um bônus consistente no recebimento de permissões extras a serem distribuídas em uma segunda rodada de alocação.

Por fim, a última forma de acomodar as reduções antecipadas seria utilizar um benchmark de emissões para a alocação de permissões, que representasse a utilização da melhor técnica disponível em um mesmo setor. Nesse caso, as atividades mais eficientes que o 
benchmark receberiam mais permissões em relação às atividades menos eficientes, o que não necessariamente aconteceria caso fosse aplicado o critério de alocação baseado em níveis históricos de emissões (grandfathering).

Note-se que, diferentemente do critério 3, em que o benchmark é utilizado para definir a quantidade de permissões por setor, pelo critério 7, o benchmark é utilizado para alocar permissões entre as fontes emissoras.

Winter relata que o NAP da Alemanha para o período de 2005-2007 (Zuteilungsgesetze 2007 ou ZuG 2007) previu a alocação das permissões entre as fontes emissoras já existentes por meio do método de grandfathering. Isto é, todas as fontes emissoras receberam as permissões de acordo com as emissões geradas em determinado período histórico. De forma a incentivar a redução de emissões, foi aplicado à quantidade de permissões alocadas entre as fontes emissoras um desconto de $3 \%$ (compliance factor).

Em linha com o critério 7 do Anexo III, Winter descreve que fontes emissoras mais antigas que teriam sido recentemente modernizadas foram premiadas com a isenção de referido compliance factor. Ainda, as fontes emissoras que combinassem geração de energia e calor receberiam uma alocação especial de permissões em reconhecimento à sua alta eficiência energética. Por fim, as fontes emissoras implantadas depois do início do primeiro período receberiam emissões de acordo com o necessário para a implementação da melhor tecnologia disponível.

Segundo Winter, no NAP para o período de 2008-2012 (Zuteilungsgesetze 2008-2012 ou ZuG 2012), todo o setor de geração de energia e os novos operadores de fontes emissoras passaram a receber permissões de acordo com benchmark calculado com base na melhor tecnologia disponível (WINTER, 2009, p. 4).

(iii) Tecnologia limpa (8)

Esse critério é visto pela Comissão Europeia como a extensão do critério de potencial de redução, aplicado no nível das fontes de emissões. Uma fonte de emissão que utiliza tecnologia limpa ou eficiente do ponto de vista energético teria um potencial menor para reduzir emissões em relação à fonte emissora similar que não adote tal tecnologia. 
Assim, segundo a comunicação da Comissão, o uso da tecnologia limpa ou eficiente não deve ser recompensado em uma fonte que pertença a uma atividade que possua baixo potencial de redução, pois essa fonte já teria sido premiada na aplicação do critério 3 em nível setorial.

O critério da tecnologia limpa também está muito relacionado ao critério das reduções antecipadas, uma vez que estas reduções são realizadas, tipicamente, por meio de investimentos em tecnologia limpa ou de eficiência energética. Desse modo, o critério 8 não poderá ser aplicado conjuntamente com o critério 7 para uma mesma fonte emissora, ao menos que se comprove que as reduções antecipadas não resultaram de investimento em tecnologia limpa.

Finalmente, vale ressaltar que por tecnologia limpa a Comissão entende "as tecnologias que tenham resultado em emissões diretas menores de GEE do que as tecnologias alternativas que poderiam ter sido realisticamente aplicadas pela fonte emissora" (COMISSÃo EUROPEIA, 2004, p. 18) ${ }^{72}$.

(iv) Competição de fontes emissoras localizadas fora da União Europeia (11)

Os Estados-membros poderão levar em consideração a competição internacional a que certa fonte emissora está submetida quando a imposição da política europeia climática tornar a fonte emissora europeia menos competitiva em relação a outras fontes emissoras não estabelecidas no território europeu.

A comunicação da Comissão Europeia ressalta que este critério não poderá ser utilizado como forma de melhorar a posição competitiva de fontes emissoras europeias em relação a fontes emissoras localizadas fora do território europeu, o que poderia ser classificado como auxílio à exportação, o que é vedado pelo Tratado da Comunidade Europeia.

\footnotetext{
72 Tradução livre do original: "By clean or energy efficient technologies, the Commission understands technologies that have resulted in lower direct emissions of covered greenhouse gases than the alternative technologies that could realistically have been deployed by the installation concerned would have led to".
} 
A Diretiva Europeia n ${ }^{\circ}$ 2009/29/EC, adotada em 23 de abril de 2009, instituiu a Fase III do EU-ETS, compreendida entre os anos 2013 e 2020. Estabelece a meta de redução de $20 \%$ das emissões realizadas em 1990, com aumento de $20 \%$ da utilização de energia renovável na matriz energética europeia, até 2020 (“Diretiva 20-20-20”). Caso os demais países se comprometessem com o mesmo objetivo no âmbito da Convenção do Clima, a Diretiva 20-20-20 previa o aumento de sua meta para 30\% em 2020. A meta prevista para 2050 é de 60-80\% abaixo dos níveis de 1990.

Na Fase III do EU-ETS, novos setores responsáveis pela emissão de GEE foram incluídos: aviação, processos petroquímicos, fabricação de amônia e alumínio e alguns processos de produção que resultam em emissões de N20.

O sistema de alocação de permissões também foi alterado para a Fase III. Em primeiro lugar, as permissões de emissões não mais serão alocadas entre os setores pelas Autoridades Nacionais e sim por um órgão central. Em segundo lugar, o leilão deve ser a regra para distribuição de permissões no setor de energia.

Com relação ao setor industrial e de aquecimento, as permissões devem ser alocadas gratuitamente com base em benchmark baseado na média de emissões de GEE liberadas por produto nas fontes emissoras posicionadas entre as $10 \%$ com o melhor desempenho. Segundo previsto na página da internet da União Europeia $^{73}$, as fontes emissoras que alcancem o padrão de referência adotado e, portanto, estejam entre as fontes emissoras mais eficientes da Europa, receberão, em princípio, todas as permissões de que necessitam para desenvolverem sua atividade. Aquelas fontes que não estejam desempenhando conforme o benchmark estabelecido receberão gratuitamente menos permissões que o necessário e terão duas opções: reduzir emissões ou adquirir permissões adicionais para cobrir o excesso de emissões.

\footnotetext{
${ }^{73}$ Disponível em: <http://ec.europa.eu/clima/policies/ets/benchmarking_en.htm>. Acesso em 24 de abril de 2011.
} 
A adoção de benchmarks como regra para o período pós-2013 visa a eliminar o efeito perverso de prover mais emissões gratuitas para as fontes que mais emitem, como poderia acontecer caso as Autoridades Nacionais não utilizassem a abordagem de benchmark para alocação das permissões em seus NAPs. Exceções à regra do benchmark são feitas para os setores mais expostos ao risco de fuga de carbono, ou seja, para aqueles setores em que o aumento de custo da produção inviabiliza a manutenção da produção dentro dos limites do mercado coberto pelo EU-ETS.

\subsubsection{Califórnia}

O California Global Warming Solutions Act, assinado em 27 de setembro de 2006 pelo então Governador Arnold Schwarznegger, introduziu no Código de Saúde e Segurança do estado norte-americano meta para redução das emissões de GEE aos níveis de 1990, até $2020^{74}$.

A lei californiana investiu o State Air Resources Board (“ARB”) de competência para monitorar e regular as fontes de emissões de GEE e determinou que a agência estatal, até janeiro de 2008, divulgasse os níveis de emissões do estado em 1990, fixando limite de emissões para as fontes emissoras. Antes mesmo do final do prazo legal, a agência publicou o inventário das emissões históricas no estado e os limites de emissões para 2020, acompanhados das regras e procedimentos para o relato das emissões de $\mathrm{GEE}^{75}$.

Em conformidade com o California Global Warming Solutions Act, o ARB aprovou, em agosto de 2011, a última versão do Scoping Plan, contendo as ações previstas para alcançar a meta de redução proposta - algo em torno de $15 \%$ das emissões projetadas em 2020 considerando-se o cenário tendencial (business as usual) ${ }^{76}$.

\footnotetext{
${ }^{74}$ Anos antes, grupo de empresas preocupadas com a proteção de suas reduções antecipadas de emissões solicitou ao Estado da Califórnia a criação de um registro voluntário de inventários de GEE. Em outubro de 2001, o California Climate Action Registry (CCAR) foi legalmente instituído, permitindo que entidades públicas e privadas pudessem calcular, monitorar e publicar suas emissões de GEE de forma acurada e transparente.

${ }^{75}$ Disponível em: <http://www.arb.ca.gov/cc/inventory/inventory.htm>. Acesso em 24 de abril de 2011.

${ }^{76}$ Disponível em: <http://www.arb.ca.gov/cc/scopingplan/document/final_supplement_to_sp_fed.pdf>, p. 11/12. Acesso em 25 de setembro de 2012.
} 
As ações em desenvolvimento pelo ARB incluem a instituição de mercado de cap-andtrade que deveria envolver cerca de $85 \%$ (oitenta e cinco por cento) das emissões da economia da Califórnia. As ações previstas no Scoping Plan deveriam ser desenvolvidas pela agência estatal e entrar em vigor a partir de janeiro de 2012.

O programa de cap-and-trade da Califórnia foi aprovado pelo ARB, em 16 de dezembro de 2010 e teve sua regulamentação concluída no final de $2011^{77}$. São previstos três períodos de compromisso. O primeiro compreende o período de $1^{\circ}$ de janeiro de 2013 a 31 de dezembro de 2014. O segundo abrange $1^{\circ}$ de janeiro de 2015 a 31 de dezembro de 2017 . O terceiro, por sua vez, abarca de $1^{\circ}$ de janeiro de 2018 até 31 de dezembro de 2020.

Enfim, o ARB Emissions Trading Program (“CA-ETS”) deverá valer a partir de janeiro de 2013 para distribuidoras de energia elétrica e grandes indústrias (geradoras de mais de $25.000 \mathrm{MtCO}_{2} \mathrm{e}$ por ano), totalizando cerca de 600 empreendimentos. A partir de 2015, englobará os setores de transporte, produção e importação de gás natural e outros combustíveis.

Cada fonte emissora deverá utilizar uma permissão para cada tonelada de $\mathrm{CO}_{2} \mathrm{e}$ emitida. O número de permissões a ser colocado no mercado no ano de 2013 visa reduzir em 2\% (dois por cento) as emissões realizadas pelas fontes em 2012. Essa quantidade deverá ser reduzida em cerca de 2\% (dois por cento) em 2014 e em 3\% (três por cento), anualmente, de 2015 até 2020.

O limite agregado de emissões para o setor de distribuição de energia consiste em 97,7 milhões de $\mathrm{MtCO}_{2}$ eq, ao qual se aplica um fator de ajuste de 98,1\% para o ano de 2013, o que resulta em um limite final de 95,8 milhões de $\mathrm{MtCO}_{2}$ eq.

${ }^{77}$ Disponível em: <http://www.arb.ca.gov/cc/capandtrade/capandtrade/programactivities.pdf〉. Acesso em 24 de abril de 2011. 
O limite agregado para os setores industriais consiste no saldo das permissões, já descontadas aquelas reservadas pelo ARB para outros propósitos. Dessa forma, tem-se aproximadamente 63-64 milhões de $\mathrm{MtCO}_{2}$ eq para o primeiro período e 285,5 milhões de $\mathrm{MtCO}_{2}$ eq para o segundo período (considerando a entrada de outros setores industriais) ${ }^{78}$.

Assim como ocorre no âmbito do EU-ETS, o CA-ETS contempla soluções para diferenciar o tratamento das fontes emissoras de acordo com o seu desempenho em termos de emissões de GEE.

As ações de redução ou sequestro de emissões havidas antes da entrada em vigor do programa de limite e comércio californiano, que tornaram algumas fontes emissoras mais eficientes do que outras fontes, foram tratadas de duas formas: por meio da certificação de emissões evitadas de projetos de compensação e como beneficiárias do critério de benchmark para alocação gratuita de permissões no setor industrial ${ }^{79}$.

(i) Projetos de compensação de emissões anteriores a 2012

Para que projetos de compensação iniciados antes de 2012 possam ser reconhecidos pelo programa, suas emissões evitadas devem estar compreendidas no período entre $1^{\circ}$ de janeiro de 2007 e 31 de dezembro de 2014.

Os projetos de compensação devem atender aos requisitos previstos no programa, entre eles, terem sido desenvolvidos de acordo com as metodologias aprovadas pelo Climate Action Reserve $^{80}$ relacionadas a florestas, florestas urbanas, substâncias que destroem a camada de ozônio e pecuária.

As fontes emissoras incluídas no CA-ETS poderão utilizar-se dos créditos advindos de projetos de compensação de emissões para cumprir até $8 \%$ (oito por cento) de seus limites de emissões.

\footnotetext{
${ }^{78}$ TILL, Dustin. California Air Board Approves Controversial Greenhouse Gas Cap-and-Trade Rules. Novembro de 2011. Disponível em: <http://www.martenlaw.com/newsletter/20111102-calif-ghg-cap-and-trade-rules〉. Acesso em 25 de setembro de 2011.

${ }^{79}$ A questão foi objeto de debate em audiência púbica havida em 10 de março de 2009. Na ocasião, representante do California Climate Action Registry apresentou manifestação em defesa do reconhecimento das reduções de emissões registradas pelos seus membros e respectiva cessão de permissões no programa de limite e comércio.

${ }^{80}$ Disponível em: <http://www.climateactionreserve.org/how/protocols>.
} 
(ii) Benchmarking como critério para distribuição gratuita de permissões

As indústrias que realizaram investimentos em eficiência energética e adotaram ações voltadas à redução voluntária de emissões antes da entrada em vigor do programa devem ser beneficiadas pelas regras que regem o sistema de distribuição gratuita de permissões para emissão.

Conforme anunciado pelo ARB, a quantidade de permissões a serem distribuídas para o setor industrial deve cobrir cerca de $90 \%$ (noventa por cento) das emissões médias históricas, com base no estabelecimento de benchmark que premia as fontes emissoras eficientes.

Ademais, assim como ocorrerá na Fase III do EU-ETS, a distribuição das permissões gratuitas para as indústrias incluídas no programa californiano será baseada na comparação da eficiência do processo com o benchmark específico do setor a que pertence. Isto é, as atividades industriais que apresentarem comparativamente menor intensidade de emissão de GEE por unidade produzida devem receber proporcionalmente mais permissões gratuitas para cobrir suas emissões.

Objetivando evitar fuga de investimentos do estado, o critério da eficiência será balanceado com o critério da produtividade. Receberão mais permissões gratuitas as atividades que mais produziram no território californiano em comparação ao benchmark setorial.

As alocações gratuitas de emissões para unidades de geração de eletricidade também devem levar em conta as especificidades da matriz energética californiana, de forma a não prejudicar a região sul do estado em que a energia é produzida com base em termelétricas a carvão. Para tanto, a fórmula para alocação das permissões deve combinar o histórico de emissões com venda de energia, consolidando critério baseado em eficiência das unidades geradoras, consideradas suas peculiaridades ${ }^{81}$.

\footnotetext{
${ }^{81}$ Chin, Dickson C.; Donelly, Thomas M. California Adopts Cap and Trade Program for Greenhouse Gas Emissions, Janeiro 2011. Disponível em: <http://www.jonesday.com/california_adopts_cap_and_trade/>. Acesso em 17 de julho de 2011.
} 
Com o objetivo de incentivar a redução de emissões ao longo do programa, está prevista a redução gradativa da alocação gratuita de permissões. Exceto para as indústrias sujeitas à fuga de carbono, que continuarão a receber $100 \%$ (cem por cento) de suas permissões de forma gratuita, as demais indústrias receberão $75 \%$ (setenta e cinco por cento) de suas permissões gratuitamente no segundo período de compromisso e $50 \%$ (cinquenta por cento) no terceiro.

Com base no exposto nos itens $i$ e $i$ acima, é válido ilustrarmos a forma como uma indústria californiana, incluída no CA-ETS, deverá demonstrar o cumprimento das metas de redução de emissões impostas pelo ARB.

Caso a fonte emissora não receba todas as permissões gratuitas de que necessita para continuar produzindo de acordo com o seu curso normal dos negócios (business as usual), deverá investir em seu processo produtivo para reduzir as suas emissões ou adquirir permissões de emissões para cobrir as suas emissões excessivas.

A aquisição de permissões poderá se dar tanto do ARB, por meio dos leilões periódicos, quanto dos agentes do mercado (entendidos esses como os operadores de fontes emissoras, investidores ou qualquer outra entidade que detenha permissões não utilizadas).

O primeiro leilão de permissões ocorreu em 14 de novembro de 2012, sendo realizado pelo ARB por meio de entidade privada contratada para tanto. Em referido leilão, foram alienadas 23.126.110 (vinte e três milhões, cento e vinte e seis mil e cento e dez) permissões para o ano de 2013 e 39.450 .000 (trinta e nove milhões e quatrocentos e cinquenta mil) permissões para o ano de 2015.

\subsection{Sistematização do ferramental doutrinário e empírico}

De forma a melhor visualizar as ferramentas doutrinárias e empíricas reunidas por meio da pesquisa realizada nas fontes doutrinárias e empíricas, propomos sintetizá-las na tabela abaixo: 
Tabela 3: Ferramentas doutrinárias e empíricas para diferenciação de atividades econômicas conforme suas emissões.

\begin{tabular}{|c|c|c|c|}
\hline & Doutrina & EU-ETS & CA-ETS \\
\hline \multirow{4}{*}{$\begin{array}{l}\text { Fixação de limite } \\
\text { agregado de emissões }\end{array}$} & Melhor tecnologia disponível & \multirow{2}{*}{$\begin{array}{l}\text { Potencial para reduzir } \\
\text { emissões (utilização de } \\
\text { benchmark setorial) }\end{array}$} & \\
\hline & Custo-benefício & & \\
\hline & Efetividade & & \\
\hline & Fuga de carbono & $\begin{array}{l}\text { Exposição à competição } \\
\text { de fontes externas à UE }\end{array}$ & $\begin{array}{lr}\text { Premiação } & \text { à } \\
\text { produtividade } & \mathrm{e} \\
\text { compensação } & \text { de } \\
\text { diferenças regionais } & \end{array}$ \\
\hline \multirow[t]{6}{*}{$\begin{array}{l}\text { Individualização } \\
\text { metas de redução }\end{array}$} & $\begin{array}{l}\text { Divisão igualitária do limite } \\
\text { agregado por fonte emissora }\end{array}$ & & \\
\hline & \multicolumn{3}{|c|}{ Divisão do limite agregado por unidade de produto } \\
\hline & Grandfathering & $\begin{array}{l}\text { Critério prevalente para } \\
\text { alocação nos setores } \\
\text { expostos à fuga de } \\
\text { carbono (Fase III) }\end{array}$ & $\begin{array}{l}\text { Critério prevalente para } \\
\text { alocação aos setores } \\
\text { expostos à fuga de } \\
\text { carbono }\end{array}$ \\
\hline & \multirow[t]{3}{*}{ Benchmarking } & Reduções antecipadas & \multirow[t]{3}{*}{ Reduções antecipadas } \\
\hline & & Tecnologia limpa & \\
\hline & & $\begin{array}{l}\text { Critério prevalente } \\
\text { alocação } \quad \text { gratuita } \\
\text { permissões (Fase III) }\end{array}$ & \\
\hline $\begin{array}{l}\text { Aceitação de reduções } \\
\text { certificadas advindas } \\
\text { de projetos de } \\
\text { compensação }\end{array}$ & & $\begin{array}{l}\text { Compensação } \quad \text { por } \\
\text { projetos de MDL e } \\
\text { Implementação Conjunta }\end{array}$ & $\begin{array}{l}\text { Compensação por } \\
\text { projetos de compensação } \\
\text { anteriores a } 2012\end{array}$ \\
\hline
\end{tabular}

Fonte: elaborada pela autora. 


\section{IDENTIFICAÇÃO DOS CRITÉRIOS ANALISADOS NOS PLANOS SETORIAIS}

No capítulo anterior, buscamos na doutrina e nas experiências internacionais critérios para fixação de limites agregados de emissões e alocação de metas de reduções entre fontes emissoras individuais para efetivação dos dispositivos constitucionais e da PNMC.

Sob a perspectiva normativa brasileira, em que a PNMC aponta primordialmente para a adoção de mecanismo de comando-e-controle para o alcance do compromisso nacional voluntário, identificamos na doutrina e nas experiências internacionais os seguintes critérios para a diferenciação das atividades econômicas conforme suas emissões: (i) potencial da atividade para reduzir emissões ${ }^{82}$; (ii) adoção antecipada de ações voltadas à redução de emissões pelas atividades econômicas em relação ao estabelecimento de políticas regulatórias e (iii) exposição do setor ao risco da fuga de carbono.

$\mathrm{Na}$ aplicação do critério relacionado ao potencial para reduzir emissões, deve-se questionar se as atividades econômicas e as fontes emissoras individuais aplicam a melhor tecnologia disponível para reduzir emissões. Caso assim seja, conclui-se que haja liberação mínima possível de emissões de GEE por unidade de produto. Em caso negativo, deve ser imposta meta de reduções de emissões compatível com a instalação de equipamentos de controle que possa efetivá-la. A concretização desse critério pode ser levada a cabo pelo estabelecimento de benchmarks para o setor ou por produto.

\footnotetext{
${ }^{82}$ Como expusemos no capítulo 3 desta dissertação, os critérios do custo-benefício e da efetividade, ao contrário do critério do potencial para reduzir emissões, não se prestam à concretização da diferenciação das atividades econômicas conforme suas emissões.
} 
Parece-nos que o critério do potencial para reduzir emissões compreende a análise sobre a utilização de tecnologia limpa pela atividade econômica, considerada separadamente como critério de alocação no EU-ETS, na medida em que, como mencionamos acima, uma fonte de emissão que utiliza tecnologia limpa ou eficiente do ponto de vista energético teria um potencial menor para reduzir emissões em relação à fonte emissora similar que não adote tal tecnologia.

Com relação ao critério da adoção antecipada de ações para a redução de emissões, deve ser perquirido se a fonte emissora individual lançou mão da instalação de tecnologias em seus processos produtivos anteriores ao estabelecimento de metas regulatórias, de forma a atingir a liberação mínima alcançável de emissões de GEE por unidade de produto ou compensar emissões por meio de projetos viabilizados fora de seu processo produtivo. Aqui entra a análise da adoção de fontes de energias eficientes e de baixa emissão de GEE, assim como compensação por projetos de sequestro de carbono (como reflorestamento). Esse segundo critério não exclui a adoção de benchmarks para o setor, em relação aos quais haverá a avaliação do desempenho da fonte emissora individual.

Por fim, com relação à exposição da atividade ao risco da fuga de carbono, deve-se analisar até que medida a imposição de metas de redução a determinada atividade econômica promove a redução de emissões de forma global e a partir de que momento o "engessamento" das emissões de uma fonte local ocasiona o aumento de emissões por fontes extraterritoriais.

Neste capítulo, nos propomos a analisar o conteúdo dos Planos Setoriais já publicados, em suas versões preliminares ou finais, para verificar se foram incorporados os três critérios expostos acima na fixação de metas para as atividades econômicas neles compreendidas.

Para tanto, os seguintes planos são considerados, em suas versões preliminares e finais ${ }^{83}$ : (i) Plano Decenal de Expansão de Energia (“PDE”); (ii) Plano Setorial da Indústria; (iii) Plano Setorial da Saúde; (iv) Plano Setorial do Transporte; (v) Plano Setorial da Mineração e (vi) Plano Setorial ABC.

\footnotetext{
${ }^{83}$ O Plano Setorial de Redução de Emissões da Siderurgia encontrava-se, até o momento da finalização desta dissertação, em elaboração.
} 
Nossa análise disseca os Planos Setoriais adotando como espinha dorsal o conteúdo mínimo proposto pelo Decreto Federal n 7.390/2010, como já exposto no segundo capítulo desta dissertação: (i) meta de redução de emissões em 2020, expressas em percentuais das projeções previstas para este ano (incluindo metas gradativas com intervalo máximo de três anos); (ii) ações a serem implementadas; (iii) definição de indicadores para o monitoramento e avaliação de sua efetividade; (iv) proposta de instrumentos de regulação e incentivo para implementação do respectivo Plano Setorial; e (v) estudos setoriais de competitividade com estimativa de custos e impactos.

\subsection{Análise dos Planos Setoriais}

\subsubsection{PDE}

Como já exposto nesta dissertação, o PDE consiste em ferramenta de planejamento governamental para o setor de energia, sendo elevado à categoria de Plano Setorial pela PNMC. A versão mais recente disponibilizada na página da internet da EPE, responsável por sua elaboração, é o PDE 2020, elaborado em 2011.

O PDE reúne informações atuais e projeções de dados relativos a quatro aspectos do setor de energia: (i) demanda de energia; (ii) oferta de energia elétrica; (iii) oferta de petróleo e seus derivados, gás natural e biocombustíveis e (iv) aspectos socioambientais e de sustentabilidade.

O PDE não possui a estrutura ou o conteúdo mínimo presente nos demais planos elaborados posteriormente ao Decreto Federal $\mathrm{n}^{\circ}$ 7.390/2010. A consideração sobre as emissões de GEE no setor de energia está inserida no eixo relativo aos aspectos ambientais e de sustentabilidade.

O PDE 2020 afirma expressamente que foi elaborado tendo entre seus objetivos o atendimento a uma meta de redução de emissões no setor energético compatível com o compromisso nacional voluntário projetado para 2020. Os outros objetivos do PDE 2020 são a segurança energética no atendimento da demanda, modicidade de preços e tarifas e universalização do acesso à energia. 
A meta fixada previamente à elaboração do PDE 2020 é anunciada, no próprio plano, como a manutenção em 2020 da mesma intensidade de emissões no setor que a constatada em 2005. Por intensidade de emissões é definida a quantidade de emissões $\left(\mathrm{kgCO}_{2} \mathrm{e}\right)$ por unidade do PIB.

Segundo o PDE 2020, a projeção do aumento de emissões do setor de energia para $2020\left(628 \mathrm{mtCO}_{2} \mathrm{e}\right)^{84}$, já aplicadas as ações previstas no plano ${ }^{85}$, é de $93 \%$ (noventa e três por cento) em relação ao índice verificado em $2005\left(329 \mathrm{mtCO}_{2} \mathrm{e}\right)^{86}$. Sendo esse aumento inferior à elevação do consumo final energético (111\%) e ao crescimento do PIB (101\%) no mesmo período, o plano conclui que a intensidade de carbono no uso da energia $\left(\mathrm{tCO}_{2} / \mathrm{tep}\right)$ e a intensidade de carbono na economia ( $\mathrm{tCO}_{2} / \mathrm{US} \$$ ) serão menores em 2020 do que em 2005.

É de se notar que o Decreto Federal $n^{\circ} 7.390 / 2010$, que regulamenta a PNMC, baseou a projeção de emissões do setor energético em cenários traçados pela EPE, estimada, na época, em $868 \mathrm{MtCO}_{2}$ eq em $2020^{87}$. Dessa forma, comparando-se a projeção do PDE 2020, que leva em conta as ações a serem implantadas em seu horizonte de planejamento, e a projeção da PNMC, temos um desvio de emissões do cenário tendencial de 38,2\% (trinta e oito inteiros e dois décimos), o que indica compatibilidade do PDE com o compromisso nacional voluntário.

\footnotetext{
${ }^{84}$ Note-se que o PDE 2020 revela que os valores projetados para 2015 e 2020 são menores em relação ao PDE anterior, pois as emissões do consumo de coque de carvão mineral no setor siderúrgico passaram a ser contabilizadas no setor de processos industriais e não mais no setor energético, como recomenda a metodologia do IPCC.

${ }^{85}$ São exemplos de ações de mitigação previstas no PDE 2020: aumento da participação de biocombustíveis na matriz de transportes, expansão de energia hidrelétrica e de outras fontes renováveis de energia e estímulo à eficiência energética.

${ }^{86}$ Os dados considerados são do Segundo Inventário Brasileiro de Emissões Antrópicas de Gases de Efeito Estufa.

${ }^{87}$ Nos termos do Anexo do Decreto Federal n ${ }^{\circ} 7.390 / 10$, "[O] cálculo das emissões de GEE decorrentes da produção e do uso da energia para 2020 fez-se por meio da construção de cenários elaborados pela Empresa de Pesquisa Energética (EPE) a partir de modelos de previsão de demanda baseados em estimativas populacionais, econômicas e de evolução da intensidade das emissões no setor energético. Por sua vez, a oferta de energia para atender essa demanda considerou hipóteses determinísticas para a composição da matriz energética em um cenário no qual a execução das medidas de redução de emissões de GEE contidas no Plano Decenal de Expansão de Energia (PDE) não ocorresse. Tal metodologia mostra-se apropriada uma vez que o PDE pode ser entendido como um cenário de baixo carbono que inclui políticas e iniciativas que objetivam a mitigação de emissões". O cenário do PDE, previsto nesse Anexo, indicava emissões de $634 \mathrm{MtCO}_{2} \mathrm{eq}$ em 2020.
} 
Com relação à meta fixada pelo PDE 2020 de manter a quantidade de emissões por unidade do PIB igual à verificada em 2005, o plano apresenta os seguintes números:

Tabela 4. Intensidade de carbono na economia brasileira.

\begin{tabular}{||l|c|c||}
\hline & 2005 & 2020 \\
\hline $\begin{array}{l}\text { Intensidade de carbono no uso da } \\
\text { energia }\left(\mathrm{kgCO}_{2} \mathrm{e} / \mathrm{tep}\right)\end{array}$ & 1.801 & 1.592 \\
\hline $\begin{array}{l}\text { Intensidade de carbono na } \\
\text { economia }\left(\mathrm{kgCO}_{2} \mathrm{e} / 10^{3} \mathrm{R} \$[2008]\right)\end{array}$ & 127,0 & 120,5 \\
\hline
\end{tabular}

Fonte: PDE 2020

A PNMC, por sua vez, não traça objetivos de manutenção ou redução da intensidade de emissões de GEE por unidade de PIB ou unidade de uso da energia, não havendo, portanto, possibilidade de comparar as projeções realizadas pela EPE com seus objetivos regulatórios.

Por fim, no eixo da oferta de energia elétrica, o PDE 2020 indica que não foram considerados no seu horizonte de planejamento novos projetos termelétricos, além daqueles que já se encontram em construção e devem iniciar operação até $2013^{88}$. Um dos motivos declarados no plano para o "abandono" das termelétricas é a sua contribuição para a emissão de $\mathrm{CO}_{2}$, além da disponibilidade de projetos hidrelétricos e de fontes de energia alternativa com custos de geração mais competitivos do que os das termelétricas.

O PDE 2020 não diferencia metas de redução de emissões por fontes emissoras, buscando atingir as reduções de emissões propostas pela PNMC no setor energético como um todo. Contudo, não fica claro quais são as ações de mitigação implementadas e os resultados esperados de cada qual, dando a entender que o alcance da meta da PNMC é circunstancial e não intencional.

Nesse sentido, não conseguimos avaliar os critérios utilizados pelo Agente Regulador para estabelecer metas dentro do setor energético, restando prejudicada a comparação entre os critérios aplicados e aqueles identificados na doutrina e experiências internacionais.

\footnotetext{
${ }^{88}$ O PDE 2019 explica que a energia proveniente dessas termelétricas foi contratada em 2007/2008 devido à insuficiência da capacidade a ser gerada por empreendimentos hidrelétricos com licenças ambientais outorgadas a tempo de possibilitar sua participação nos leilões. Adicionalmente, não havia sido sinalizada uma disponibilidade adequada de gás natural para o mercado termelétrico.
} 


\subsubsection{Plano Setorial da Indústria}

A versão preliminar do Plano Setorial da Indústria foi disponibilizada para consulta pública de 15 de junho a 15 de agosto de 2012 na página da internet do Ministério do Meio Ambiente. O órgão responsável por sua elaboração foi o Ministério do Desenvolvimento, Indústria e Comércio Exterior. Até o momento da finalização desta dissertação, a sua versão final não havia sido publicada.

O Plano Setorial da Indústria sustenta-se em três pilares: (i) implantação gradual de um sistema de medição, relato e verificação das emissões de GEE da atividade industrial; (ii) elaboração de plano de ação contendo medidas e instrumentos de incentivo à redução de emissões; e (iii) criação de comissão técnica, composta por representantes do governo, indústria, sociedade civil e meio acadêmico, responsável pelo detalhamento das ações do plano, monitoramento e revisão periódica.

(A) Meta de redução de emissões em 2020, expressas em percentuais das projeções previstas para este ano (incluindo metas gradativas com intervalo máximo de três anos)

O Plano Setorial da Indústria institui "meta de referência" de redução de emissões em processos industriais e derivadas do uso de energia de $5 \%$ (cinco por cento) em relação ao cenário tendencial (business as usual) projetado para 2020. A meta equivale à redução de 16,2 $\mathrm{MtCO}_{2} \mathrm{eq}$, o que indica a meta de emissão de 308,16 $\mathrm{MtCO}_{2}$ eq pela indústria de transformação em $2020^{89}$. Não são, contudo, disponibilizados os critérios aplicados para o estabelecimento de tal meta de referência.

Prevê-se a revisão da meta de referência e eventual estabelecimento de redução de emissões por gás, setor ou empresa, ao longo dos próximos anos, em períodos não superiores a dois anos, com base no trabalho da Comissão Técnica do Plano Indústria (“CTPIn”) a ser instituída.

\footnotetext{
${ }^{89}$ A título de referência, de acordo com o Segundo Inventário Nacional, em 2005 as emissões industriais relativas ao uso de energia foram de $78,83 \mathrm{MtCO}_{2}$ eq e as emissões derivadas de processos industriais consistiram em 77, $19 \mathrm{MtCO}_{2} \mathrm{eq}$.
} 
A despeito da fixação da meta de referência, da previsão de sua revisão periódica e da sinalização de sua individualização por gás, setor ou empresa, o plano registra que as reduções na indústria de transformação não são necessárias para o cumprimento do compromisso nacional voluntário da PNMC. Nos termos do Plano Setorial da Indústria,

[É] possível atingir uma redução de até $40 \%$ das emissões em relação à projeção de 2020, superando portanto a meta de 36,1\% prevista na PNMC, apenas com as reduções previstas nos planos setoriais finalizados em 2010 (Decreto 7.390/2010). (BRASIL, 2012b, p. 21)

É neste contexto que o Plano Setorial da Indústria afirma ser o papel da meta um “estímulo à melhoria da eficiência dos processos industriais e não um constrangimento ao crescimento econômico" (BRASIL, 2012b, p. 19).

O Plano Setorial da Indústria alerta para a dificuldade de alcance da meta pela inexistência de instrumentos de mensuração precisos para orientar as políticas nacionais de redução de emissões e subsidiar o processo de negociação internacional.

Segundo afirmado no plano, as peculiaridades das plantas industriais em "termos de produtos, de porte e de atualização tecnológica exige mecanismos de medição muito mais desagregados do que aqueles incorporados aos Inventários Nacionais”. Nesse sentido, “a proposta do Plano Indústria é institucionalizar metodologia bottom up ${ }^{90}$ para contabilidade de emissões na indústria que contemple emissões de GEE pertencentes aos Escopos 1 e 2 da metodologia do GHG Protocol ${ }^{91 "}$ (BRASIL, 2012b, p. 21).

\footnotetext{
${ }^{90}$ Como já exposto nesta dissertação (vide nota 35), a abordagem bottom up propõe a coleta de dados a partir das fontes emissoras enquanto a top down envolve as emissões gerais de cada setor.

${ }^{91}$ Trata-se de iniciativa resultante da parceria entre o World Resources Institute ("WRI") e o World Business Council for Sustainable Development ("WBCSD"). O GHG Protocol disponibiliza metodologia de cálculo, gerenciamento e divulgação de emissões de GEE. Reúne ferramentas para o cálculo de emissões específicas para diversos setores. O Programa Brasileiro GHG Protocol conta com a adesão de oitenta e oito empresas que elaboraram e divulgaram seus inventários de GEE relativos às emissões de 2011, em agosto de 2012. Dados disponíveis no site <http://www.ghgprotocolbrasil.com.br/>, acesso em 06 de outubro de 2012. Note-se que a Decisão de Diretoria da Companhia Ambiental do Estado de São Paulo ("CETESB") n 254/2012/V/I, de 22 de agosto de 2012, que dispõe sobre os critérios para a elaboração do inventário de emissões de GEE no Estado de São Paulo, determina que, até que a CETESB tenha definido metodologia própria para o cálculo das emissões, poderá ser utilizada a norma ABNT NBR ISO 14. 064-1 ou a do GHG Protocol.
} 
Ações a serem implementadas

O Plano Setorial da Indústria preconiza que as ações para a redução de emissões a serem implementadas pela indústria de transformação deverão levar em conta as características deste macrossetor, diretamente relacionadas com o crescimento econômico do País (BRASIL, 2012b, p. 22):

(i) a continuidade do desenvolvimento econômico e social no Brasil demanda o crescimento acelerado do consumo de bens industriais (o consumo per capita desses bens no país está abaixo da média mundial);

(ii) os produtos da indústria de transformação são quase todos comercializáveis internacionalmente, sendo que as elevações internas de custo implicam perda de competitividade e risco de substituição de produção doméstica por importações;

(iii) os bens industriais mais intensivos em emissões de GEE possuem aplicação disseminada no tecido econômico e baixa possibilidade de substituição técnica e econômica, isto é, são necessários para o desenvolvimento da economia e não possuem substitutivos próximos e

(iv) a elevada intensidade das emissões de GEE de alguns setores explica-se por características intrínsecas da atividade tanto pela centralidade do carbono em processos industriais de transformação químico-física (redução, calcinação, etc.) de bens minerais quanto pelo consumo em larga escala de combustíveis fósseis (particularmente na geração de calor). Embora existam oportunidades de ganhos incrementais, será muito difícil num horizonte previsível de tempo desenvolver alternativas tecnológicas que permitam produzir diversos produtos industriais sem incorrer em vultosas emissões de GEE. 
Com base nos pontos acima mencionados, o Plano Setorial da Indústria prevê três efeitos da aplicação de políticas de redução de emissões de GEE que "dificultem a ampliação da produção industrial necessária ao desenvolvimento" (BRASIL, 2012b, p. 22):

(i) esforço das empresas em reduzir suas emissões por unidade de produto mediante a adoção de tecnologias menos intensivas em carbono (substituição de combustíveis e eficiência energética);

(ii) redução do consumo devido aos preços mais elevados, com possível substituição por produtos, industriais ou não, de baixo carbono (por exemplo, cimento por adobe, aço por madeira);

(iii) substituição do produto brasileiro devido à perda de competitividade por importações - a redução da competitividade provocaria ainda a redução das exportações de produtos industriais brasileiros.

O Plano Setorial da Indústria afirma que os dois primeiros efeitos provocariam reduções de emissões, devendo, o primeiro deles, estar no centro das ações por ele propostas. Ainda nos termos do plano, o terceiro efeito não seria desejado por não garantir redução líquida de GEE, pois o aumento de emissões liberadas pelo processo de fabricação do produto importado compensaria a redução local das emissões.

Conclui, portanto, que "a questão mais importante para a estratégia do Plano da Indústria é garantir que a produção nacional seja, em média, mais eficiente em termos de emissões de GEE em comparação com o restante do mundo"92.

\footnotetext{
${ }^{92}$ Continua o Plano Setorial da Indústria: "As emissões no Brasil de GEE por unidade (tonelada) de produto de bens industriais, ao menos nos setores examinados e que são responsáveis pela maior parte dos GEE, são menores do que na maior parte de nossos concorrentes, o que se explica tanto pela maior eficiência das instalações industriais no processamento do carbono e de outros GEE quanto pela participação excepcionalmente elevada para os padrões internacionais de fontes renováveis na matriz elétrica brasileira (hidroeletricidade e biomassa)". (BRASIL, 2012b, p. 23)
} 
O foco do Plano Setorial da Indústria na redução de emissões por unidade de produto e a preocupação com a potencial fuga de carbono advinda das políticas regulatórias revelam dois dos três critérios identificados em nossa pesquisa para fixação de metas de redução de emissões baseadas na diferenciação das atividades econômicas conforme o seu impacto ao clima: o potencial da atividade para reduzir emissões e a exposição do setor à fuga de carbono.

É de se notar que, em linha com o Plano da Indústria, como visto no segundo capítulo desta dissertação, a CNI propôs a comparação entre a intensidade de emissões e emissões totais dos setores nacionais com as dos setores similares em outros países, com o objetivo de avaliar o impacto nas emissões globais associadas a determinados produtos, caso estes deixem de ser produzidos no país ou passem a ser produzidos no Brasil (CNI, 2011). Para tanto, propõe o "[D]esenvolvimento de estudos específicos com avaliações sócio e técnicoeconômicas de possíveis medidas de redução de emissões em cada setor (contemplando, inter allia, projetos de eficiência energética, processos industriais, substituição de combustíveis e manejo de resíduos)".

Por fim, o Plano Setorial da Indústria propõe que o alvo de suas ações sejam os setores responsáveis por $90 \%$ das emissões diretas da indústria de transformação e por mais da metade das emissões derivadas da queima de combustíveis fósseis na indústria: (i) alumínio; (ii) cal; (iii) cimento; (iv) ferro-gusa e aço; (v) papel e celulose; (vi) química; e (vii) vidro. Esses setores industriais deverão contabilizar emissões, assumir compromissos setoriais e serem contemplados por "instrumentos customizados de fomento à eficiência de emissões" (BRASIL, 2012b, p. 23). Ao passo das revisões do plano, deverão ser incorporados outros setores.

(C) Definição de indicadores para o monitoramento e avaliação de sua efetividade.

A CTPIn, ainda a ser instituída, será responsável pelo monitoramento das ações a serem implementadas pelas atividades econômicas englobadas no Plano Setorial da Indústria. 
(D) Proposta de instrumentos de regulação e incentivo para implementação do respectivo Plano Setorial.

Considerando as premissas do Plano Setorial da Indústria, expostas no item 4.2.2, são propostos cinco eixos de ação, que visam promover as reduções de emissões na indústria de transformação (BRASIL, 2012b, p. 30):

(i) criação de infraestrutura para o monitoramento, relato e verificação de emissões tal como criação de bancos de dados de atores de emissão e capacitação técnica para coleta de dados (as empresas dos setores do plano deverão realizar inventários corporativos de emissão anuais a partir de 2013 tomando-se como referência o ano de 2012);

(ii) promover o aumento da reciclagem e o aproveitamento de coprodutos;

(iii) promover a eficiência energética e a cogeração na indústria;

(iv) fortalecer as iniciativas voluntárias de associações e empresas para a redução de emissões; e,

(v) facilitar o desenvolvimento e a disseminação de tecnologias de baixo carbono.

Embora possamos deduzir da natureza das linhas de ação propostas que o Agente Regulador tem papel determinante para o êxito do Plano Setorial da Indústria, a sua versão preliminar não detalha as formas de incentivo e de regulação que deverão ser implementadas. 
(E) Estudos setoriais de competitividade com estimativa de custos e impactos.

O Plano Setorial da Indústria elenca como um dos principais objetivos a serem alcançados entre 2012 e 2020 a manutenção da eficiência em emissões específicas dos setores que estão “em boa posição na comparação internacional” (BRASIL, 2012b, p. 29).

Contudo, o plano não expõe quais são estes setores e as referências adotadas como padrão para comparação internacional. Prevê, para tanto, a realização de "estudos de linha de base e cenários tendenciais de emissões, levantamento de tecnologias de baixo carbono e oportunidades de mitigação nas cadeias produtivas dos setores considerados" (BRASIL, 2012b, p. 29).

\subsubsection{Plano Setorial da Saúde}

A versão preliminar do Plano Setorial da Saúde, coordenado pelo Ministério da Saúde e pela Secretaria de Vigilância em Saúde, também foi disponibilizada para consulta pública de 15 de junho a 15 de agosto de 2012 na página da internet do Ministério do Meio Ambiente. Até o momento da finalização desta dissertação, a sua versão final não havia sido publicada.

O objetivo macro do Plano Setorial da Saúde é estabelecer "diretrizes, metas e estratégias nacionais para contribuir com medidas de mitigação e direcionar medidas de adaptação dos processos e serviços do SUS [Sistema Único de Saúde] frente aos impactos da mudança do clima".

Para tanto, referido plano estrutura-se nos seguintes eixos de intervenção:

(i) Vigilância em saúde;

(ii) Atenção à saúde;

(iii) Promoção e educação em saúde;

(iv) Pesquisa em saúde. 
Embora o plano tenha como um dos seus objetivos a mitigação das emissões no setor (cujas fontes principais são as unidades de saúde, resíduos de saúde, frota de veículos, indústria farmacêutica, entre outras), os eixos de intervenção convergem para a promoção da educação e da adaptação às mudanças do clima.

A PNMC não definiu a projeção das emissões de GEE pelo setor em 2020 e o Plano Setorial da Saúde tampouco previu metas de redução de emissões. Assim, não há material a ser analisado sob a perspectiva da aplicação de critérios para a fixação de metas para o setor ou alocação de ônus de redução entre fontes individuais de emissão.

\subsubsection{Plano Setorial do Transporte}

O Plano Setorial do Transporte foi um dos quatro planos disponibilizados para consulta pública de 15 de junho a 15 de agosto de 2012, na página da internet do Ministério do Meio Ambiente. Os coordenadores de sua elaboração foram os Ministérios dos Transportes e das Cidades. Até o momento da finalização desta dissertação, a sua versão final não havia sido publicada.

Tal plano tem como foco duas atividades principais: transporte de carga (rodoviário, ferroviário e hidroviário) e transporte de passageiros (individual motorizado, público sobre pneus e público sobre trilhos).

O objetivo geral do Plano Setorial do Transporte é

(...) contribuir para a mitigação das emissões de GEE no setor, por meio de iniciativas que levam à ampliação da infraestrutura de transporte de cargas e à maior utilização de modos mais eficientes energeticamente e, no setor de mobilidade urbana, ao aumento do uso de sistemas eficientes de transporte público de passageiros, contribuindo para a consecução dos compromissos assumidos voluntariamente pelo Brasil. (BRASIL, 2012a, p. 16) 
O plano traz objetivos específicos que auxiliam no alcance do objetivo geral, relativos ao ganho de conhecimento sobre as emissões do setor, alinhamento com políticas públicas já existentes para o transporte, entre outros.

(A) Meta de redução de emissões em 2020, expressas em percentuais das projeções previstas para este ano (incluindo metas gradativas com intervalo máximo de três anos)

Segundo o Plano Setorial do Transporte as emissões do transporte rodoviário de cargas foram de 63 Mt em 2010, das quais 90\% foram liberadas por caminhões pesados e semipesados. As emissões do transporte ferroviário, por sua vez, contabilizaram 3,05 Mt em 2010. Em terceiro lugar, estima-se que o transporte hidroviário tenha emitido $1,9 \mathrm{MtCO}_{2} \mathrm{em}$ 2010.

Com relação ao transporte de passageiros, os dados apresentados pelo Plano do Transporte foram extraídos do $1^{\circ}$ Inventário Nacional de Emissões Atmosféricas por Veículos Automotores Rodoviários publicado pelo Ministério do Meio Ambiente. Referido inventário aponta que o consumo de combustível fóssil responde ainda por $70 \%$ do total consumido no transporte rodoviário de passageiros em 2010, a despeito da crescente utilização do etanol. Vale ressaltar que o transporte individual foi responsável por $70 \%$ desse consumo.

Por consequência, as emissões de $\mathrm{CO}_{2}$ geradas com a queima de combustíveis no transporte rodoviário de passageiros foram de 89 Mt em 2010 (51\% pelos automóveis; 12\% pelos veículos comerciais leves; $5 \%$ por motocicletas; $6 \%$ por ônibus rodoviários e $26 \%$ por ônibus urbanos, sendo que o transporte individual somou $68 \%$ e o transporte coletivo, $32 \%$ ) (BRASIL, 2012a, p. 56).

Com base no Plano Nacional de Logística e Transportes ("PNLT 2011”), as projeções para 2020 levem em consideração a queda da participação do modo rodoviário no transporte de cargas, de 58\% em 2010 para 45\% em 2020, por conta do aumento da participação dos modos ferroviário (de 25\% para 35\%) e hidroviário (de 12\% para 16\%). No cenário do PNLT 2011, as emissões projetadas para 2020 para o transporte de cargas atingem $98 \mathrm{MtCO}_{2}$. 
Considerando-se a malha viária existente atualmente, as emissões seriam de 101 $\mathrm{MtCO}_{2}$. No cenário do PNLT o "transporte rodoviário responderá por $88 \%$ das emissões, seguido pelo ferroviário, com 8\%, e pelo hidroviário, com 4\%” (BRASIL, 2012a, p. 56).

Observa-se, portanto, que a concretização do PNLT levará à redução de $3 \%$ das emissões em comparação com o cenário em que o PNLT não é implantado.

As projeções de emissões para o transporte rodoviário de passageiros levaram em consideração cenário hipotético em que não ocorreriam obras de implantação de novos projetos de infraestrutura de mobilidade urbana. O cenário tendencial indica que, em 2020, as emissões de $\mathrm{CO}_{2}$ alcançarão $150 \mathrm{Mt}$, o que representa aumento de 65,9\% em relação ao ano de 2010 (BRASIL, 2012a, p. 57).

No cenário dos investimentos previstos, o plano aponta o potencial máximo de redução de emissões de 2,6 $\mathrm{MtCO}_{2}$ por ano, totalizando 14,3 $\mathrm{MtCO}_{2}$ em 2020, em relação ao cenário tendencial. A redução da curva de crescimento das emissões de GEE pela implementação dos projetos de mobilidade urbana previstos atualmente é de $2 \%$ das emissões totais da atividade de transporte de passageiros ${ }^{93}$.

O Plano Setorial do Transporte não emprega nenhum dos critérios identificados em nossa pesquisa para a fixação de meta setorial de redução de GEE. As metas propostas são o resultado da comparação entre o cenário tendencial e a adoção de políticas públicas setoriais em curso.

\footnotetext{
${ }^{93}$ O Plano Setorial do Transporte afirma que os cálculos realizados para estimar as projeções de emissões para 2020, no cenário de investimentos atuais, contaram com a simplificação das variáveis existentes. Nos termos do plano, "[O] trabalho possui limitações, decorrentes da incerteza sobre o impacto da implementação de infraestrutura de transporte público e não motorizado na escolha do modo e na divisão modal das viagens realizadas pela população. É necessária a realização de atividades que possibilitem a obtenção de dados e informações mais precisas sobre os projetos de mobilidade urbana que estão sob responsabilidade dos governos estaduais e municipais, para se ter um dimensionamento mais preciso da infraestrutura que será implantada no país até o ano de 2020". (BRASIL, 2012a, p. 69)
} 
As ações que deverão evitar emissões advindas do transporte de cargas até 2020 são as propostas no PNLT 2011. Foram considerados 348 projetos previstos no plano ${ }^{94}$, dentre obras rodoviárias, ferroviárias e hidroviárias, que, por alterarem a participação dos modos no sistema viário brasileiro, proporcionam redução de $\mathrm{CO}_{2}$ em comparação ao cenário de referência, em que a malha viária não recebe os investimentos previstos pelo PNLT $2011^{95}$.

No que diz respeito ao transporte urbano de passageiros, o Plano Setorial do Transporte pauta-se no conjunto de projetos de mobilidade urbana associados à Copa do Mundo e ao Plano de Aceleração do Crescimento Mobilidade Grandes Cidades, investimentos do BNDES, além de outras iniciativas relevantes no âmbito dos governos estaduais e municipais. Os projetos considerados pelo Plano do Transporte abarcam "implantação, expansão e melhorias em infraestrutura de transporte público e não motorizado" (BRASIL, 2012a, p. 218), o que implica aumento do número de passageiros atendidos e melhoria da eficiência energética dos transportes coletivos.

(C) Definição de indicadores para o monitoramento e avaliação de sua efetividade

O monitoramento da efetividade do Plano Setorial do Transporte se valerá do monitoramento rotineiro do Ministério dos Transportes sobre os empreendimentos rodoviários, ferroviários e hidroviários, por meio de "visitas técnicas e análise crítica do cronograma de realização e avanço físico e financeiro das obras” (BRASIL, 2012a, p. 44).

\footnotetext{
${ }^{94}$ Agrupados em 24 grupos: Ligação Ferroviária Transnordestina à Hidrovia do São Francisco, Ligação Ferroviária do Jucurutu/RN a Porto do Mangue/RN, Ferrovias do Nordeste Setentrional, Ligações ferroviárias no estado da Bahia, Ferrovia Transcontinental entre divisa do Peru/Brasil e Vilhena/RO, Ferrovia Transcontinental trecho entre Ferrovia Norte-Sul e o estado do Rio de Janeiro, Ligação Ferroviária entre os estados de Goiás e Rio de Janeiro, Ligação Ferroviária Teixeira de Freitas a Aracruz, Remodelagem da Ligação Ferroviária Corumbá a Santos, Ligação Ferroviária entre Alto Araguaia e Uberlândia, Remodelagem de ferrovias de Minas Gerais, Construção da Ligação Ferroviária na Serra dos Tigres/MG, Remodelagem de ferrovias do estado do Rio de Janeiro, Construção de Ferrovias da Região Sul do Brasil, Remodelagem de Ferrovias da Região Sul do Brasil, Hidrovias da Amazônia, Hidrovia Teles Pires-Tapajós, Hidrovias Tocantins-Araguaia, Hidrovia do Parnaíba, Afluentes do Rio São Francisco, Extensão da Hidrovia Paraguai-Paraná até Cuiabá, Rios Paranaíba e Grande, Remodelagem de trecho da Ferronorte e Projetos Rodoviários.

${ }^{95}$ Note-se que o PNLT é indicativo e não vinculativo, dependendo do engajamento de diversos atores e de recursos não só federais, como dos demais entes federativos.
} 
Propõe-se também a realização do monitoramento das emissões por meio da realização de inventários bianuais na forma do "10 Inventário Nacional de Emissões Atmosféricas por Veículos Automotores Rodoviários" e do "10 Inventário Nacional de Emissões Atmosféricas do Transporte Ferroviário de Cargas".

No que diz respeito à implementação das ações relativas a transporte de passageiros, o Plano Setorial do Transporte atesta que será necessária a criação de "mecanismos para o monitoramento de seu desenvolvimento e implantação, bem como a quantificação das reduções de emissões efetivamente proporcionadas pela sua operação" (BRASIL, 2012a, p. 70).

São apontados pelo plano alguns indicadores para acompanhamento da implantação das obras de infraestrutura para melhoria da mobilidade urbana previstas no plano, sendo eles: “(i) Implantação dos projetos pactuados na Matriz de Responsabilidade da Copa FIFA 2014 (km e \%, por modo); (ii) Implantação dos projetos do Programa de Aceleração do Crescimento Mobilidade Grandes Cidades (km e \%, por modo) e (iii) Implantação dos projetos sob responsabilidade dos governos estaduais e municipais (km e \%, por modo)" (BRASIL, 2012a, p. 70).

(D) Proposta de instrumentos de regulação e incentivo para implementação do respectivo Plano Setorial

O PNLT, sobre o qual se sustenta o Plano Setorial do Transporte, é indicativo e não vinculativo. Sua execução depende do engajamento de diversos atores interessados, assim como de recursos da União e dos demais entes federativos. Os recursos públicos a serem destinados às obras previstas deverão ser inscritos nos Planos Plurianuais e leis orçamentárias anuais.

Para viabilizar suas ações, o Plano Setorial do Transporte indica a necessidade de melhoria na qualidade de informações sobre o setor e na elaboração de inventários de emissões de GEE. Além disso, prevê a elaboração de estudos sobre as opções de logística que levem à transferência modal para opções com menor intensidade de emissões de carbono. 
O Plano Setorial do Transporte determina ainda a coordenação de instrumentos previstos tanto na PNMC como na Lei Federal $n^{\circ}$ 12.587/2012 ("Política Nacional de Mobilidade Urbana"). Para o financiamento de suas ações, serão utilizados recursos do Fundo Nacional sobre Mudança do Clima, já mencionado nesta dissertação, e do Fundo Social, criado pela Lei Federal $\mathrm{n}^{\circ} 12.351 / 2010$ com a finalidade de compensar a exploração das jazidas petrolíferas do Pré-Sal.

(E) Estudos setoriais de competitividade com estimativa de custos e impactos

O Plano Setorial do Transporte não aborda a questão dos custos e impactos da adoção de medidas de mitigação para a competitividade do setor, visto não se tratar de setor produtivo e, portanto, não estar exposto à concorrência internacional.

\subsubsection{Plano Setorial da Mineração}

A elaboração do Plano Setorial da Mineração foi coordenada pela Casa Civil da Presidência da República e pelo Ministério de Minas e Energia. Sua base é constituída pelo Primeiro Inventário de Gases de Efeito Estufa do Setor Mineral, elaborado em 2010, pelo Instituto Brasileiro de Mineração ("IBRAM") e pelo Plano Nacional de Mineração 2030, publicado pelo Ministério de Minas e Energia (“PNM 2030”) em 2011.

A versão preliminar do Plano Setorial da Mineração também foi disponibilizada para consulta pública de 15 de junho a 15 de agosto de 2012, na página da internet do Ministério do Meio Ambiente. Até o momento da finalização desta dissertação, a sua versão final não havia sido publicada. 
O Plano Setorial da Mineração traz diagnóstico das emissões derivadas das atividades que compõem a cadeia de valor do setor: lavra, beneficiamento físico, pelotização e transporte interno $^{96}$. Em 2008, referidas emissões contabilizaram 10 milhões de toneladas de $\mathrm{CO}_{2} \mathrm{eq}$, representando 0,5\% das emissões nacionais, algo considerado pelo plano de pouca relevância, considerando-se a participação do setor no PIB (4,2\%) e nas exportações brasileiras (20\%). As emissões projetadas para 2020 são da ordem de 17,4 milhões de toneladas de $\mathrm{CO}_{2}$ eq.

Segundo o plano, as principais fontes emissoras do setor são a extração e o beneficiamento de minério de ferro e de agregados (areia e pedra britada para construção civil) e o processamento de minério de ferro em pelotas. Referidas atividades são responsáveis por $80 \%$ das emissões projetadas para 2020.

O processo de pelotização, que deve liberar 50\% das emissões projetadas para 2020, é a maior fonte emissora do setor. Contudo, esse processo no Brasil é benchmark mundial em relação às emissões de $\mathrm{CO}_{2}$ devido à utilização de novas tecnologias e combustíveis que geram baixa emissão.

Como objetivo geral, o Plano Setorial da Mineração visa "promover uma análise setorial" (...) "com vista ao abatimento de emissões de GEE na mineração, mediante iniciativas das próprias empresas de abatimento de emissões relacionadas principalmente à eficiência energética e à redução no consumo de combustíveis com alto teor de carbono não renovável” (BRASIL, 2012d, p. 47). O Plano cita objetivos específicos para o alcance do objetivo macro, valendo citar, dentre eles, a promoção de esforços para transformar as boas práticas de redução de emissões de GEE em um padrão nacional.

\footnotetext{
96 As atividades de processamento químico mineral e de transporte externo deverão ser analisadas nos Planos Setoriais da Indústria e do Transporte, respectivamente.
} 
(A) Meta de redução de emissões em 2020, expressas em percentuais das projeções previstas para este ano (incluindo metas gradativas com intervalo máximo de três anos)

O Plano Setorial da Mineração prevê o potencial de abatimento de emissões de acordo com as iniciativas que podem ser adotadas pelas empresas do setor, em três cenários de baixo carbono, considerando diversos níveis de alcance e barreiras existentes (sintetizados na tabela abaixo $^{97}$.

Tabela 5. Potencial de abatimento de emissões de programas por cenário.

\begin{tabular}{|c|c|c|c|}
\hline \multirow{2}{*}{ Programa } & \multicolumn{3}{|c|}{$\begin{array}{c}\text { Potencial de abatimento após superadas as barreiras para implementação de cada } \\
\text { programa }\left(\mathrm{t} \mathrm{CO}_{2} \mathrm{e}\right)\end{array}$} \\
\cline { 2 - 4 } & Cenário 1 & Cenário 2 & Cenário 3 \\
\hline $\begin{array}{c}\text { Alteração da fonte } \\
\text { energética usada nos } \\
\text { processos }\end{array}$ & 265.382 & 189.950 & 105.973 \\
\hline $\begin{array}{c}\text { Otimização dos ativos } \\
\text { na mineração }\end{array}$ & 335.615 & 201.504 & 163.470 \\
\hline $\begin{array}{c}\text { Uso de novas } \\
\text { tecnologias de } \\
\text { mineração }\end{array}$ & 2.107 .413 & 835.099 & 466.940 \\
\hline Total & 2.718 .691 & & 739.537 \\
\hline
\end{tabular}

Fonte: (BRASIL, 2012d)

O Plano Setorial da Mineração não fixa meta de redução em percentual com relação às projeções de 2020, mas, a partir dos números revelados para cada programa e cenário, tem-se que a taxa de redução poderá alcançar de 4,2\% até 15,5\% das emissões projetadas para 2020.

\footnotetext{
${ }^{97}$ Os cenários são descritos pelo Plano Setorial da Mineração como segue: "Cenário 1 - considera que o alcance das iniciativas será o máximo possível dado o conhecimento atual da tecnologia de produção; Cenário 2 considera as barreiras financeiras, políticas e culturais, mas adota uma visão positiva das ações que podem ser tomadas para superar tais barreiras; Cenário 3 - considera as barreiras de forma mais crítica e limita o alcance das iniciativas a situações claramente benéficas para a sociedade e para os entes privados". (BRASIL, 2012d, p. 49)
} 
O potencial de abatimento total no setor da mineração foi construído a partir da somatória do potencial de abatimento de reduções por cadeia de valor de cada minério. $\mathrm{O}$ potencial específico de cada uma delas foi calculado a partir da formação de índices de emissão por minério, previsão da produção para 2020 e consequentes emissões futuras.

Significa dizer que o Plano Setorial da Mineração identificou a quantidade de emissões médias por tonelada de minério $\left(\mathrm{kg} \mathrm{CO}_{2} \mathrm{e} \mathrm{ROM}^{98}\right)$ e o quanto é possível alcançar de reduções de emissões nos respectivos processos produtivos, assumindo três diferentes cenários.

O critério de análise do potencial da atividade para reduzir emissões foi, portanto, utilizado pelo Plano Setorial da Mineração como ferramenta para estimar o quanto de redução é possível se alcançar por minério e no setor como um todo.

Tabela 6. Formação do Índice de emissão de 10 minérios.

\begin{tabular}{|c|c|c|c|}
\hline Minério & $\begin{array}{c}\text { Total de emissões } \\
\text { inventariado }\left(\mathrm{tCO}_{2} \mathrm{eq}\right)\end{array}$ & $\begin{array}{c}\text { Total de produção } 2008 \\
\text { (t de } \mathrm{ROM})\end{array}$ & $\begin{array}{c}\text { Índice de emissão (kg } \\
\left.\mathrm{CO}_{2} \mathrm{eq} \mathrm{ROM}\right)\end{array}$ \\
\hline Bauxita & 379.500 & 38.219 .777 & 9,93 \\
\hline Cobre & 308.305 & 38.787 .612 & 7,95 \\
\hline Caulim & 317.212 & 7.911 .970 & 40,09 \\
\hline Ferro & 1.516 .380 & 491.524 .678 & 3,09 \\
\hline Pelotas & 5.957 .420 & 55.300 .000 & 107,73 \\
\hline Níquel & 14.169 & 6.731 .152 & 2,10 \\
\hline Zinco & 22.240 & 2.241 .207 & 9,92 \\
\hline Manganês & 8.496 & 5.574 .401 & 1,52 \\
\hline Nióbio & 13.948 & 20.969 .928 & 0,67 \\
\hline Potássio & 20.231 & 2.562 .250 & 7,90 \\
\hline Fonte & Inventário IBRAM & $\begin{array}{l}\text { Anuário Mineral } \\
\text { Brasileiro - } 2009\end{array}$ & Cálculo \\
\hline
\end{tabular}

Fonte: (BRASIL, 2012d, p. 51)

\footnotetext{
${ }^{98}$ ROM significa Run of Mine, isto é, a quantidade de minério que é extraída e comercializada.
} 
Os dez minérios listados na tabela acima tinham as suas emissões inventariadas, com a participação de 33 companhias do setor, que representavam 80\% (oitenta por cento) da produção. A partir do inventário, dividiu-se o total de emissões pela produção mineral do anobase. Optou-se pelo ano-base de 2008, pois a mineração brasileira ainda não havia sido afetada pela crise econômica que afetou o setor posteriormente.

Os resultados alcançados foram comparados com benchmarks nacionais $\mathrm{e}$ internacionais, para garantir sua correspondência com a realidade. Foram, ainda, realizadas entrevistas com especialistas e visitas às empresas para análise do consumo do processo produtivo.

Os demais minérios, cujas emissões não eram inventariadas, sofreram processos peculiares para a formação de seus índices específicos.

(B) Ações a serem implementadas

Segundo exposto no Plano Setorial da Mineração, foram estudadas em torno de 70 iniciativas de abatimento, sendo que 12 delas foram escolhidas para serem agrupadas em três programas, por apresentarem maior potencial de abatimento e facilidade de implantação no contexto brasileiro. Seguem as ações propostas a serem implementadas no setor (BRASIL, 2012d, p. 58/59):

(i) Alteração da fonte energética utilizada nos processos - programa constituído de iniciativas de substituição de combustíveis de alto teor de carbono não renovável por combustíveis renováveis ou com menor teor de carbono não renovável. Um exemplo de iniciativa é a substituição do uso de óleo combustível por gás natural nas usinas de pelotização;

(ii) Otimização dos ativos da mineração - programa constituído de iniciativas de troca de equipamentos ou instalação de peças que otimizem o consumo de combustível ou eletricidade. Um exemplo de iniciativa é a renovação progressiva da frota por caminhões com maior capacidade e melhor nível de consumo de combustível; 
(iii) Uso de novas tecnologias na mineração - programa constituído de iniciativas de alteração de projeto das minas e uso de novas tecnologias de mineração. Um exemplo de iniciativa é a britagem na mina e o uso de correias transportadoras, em substituição ao uso de caminhões e britagem na área de beneficiamento.

Os programas descritos acima foram desenhados para as atividades responsáveis por 80\% das emissões, conforme já mencionado acima. Consta em apêndice ao plano tabela descritiva do "acesso" de cada iniciativa ao total de produção previsto em 2020 por minério, isto é, o quanto cada iniciativa pode ser aplicada nas cadeias de valor dos minérios, nos três diferentes cenários previstos.

(C) Definição de indicadores para o monitoramento e avaliação de sua efetividade

O Plano Setorial da Mineração traz indicadores iniciais de monitoramento das iniciativas contidas em cada programa, que deverão ser revistos periodicamente. $\mathrm{O}$ monitoramento dos indicadores estará a cargo do Ministério de Minas e Energia e deverá contar com a participação dos segmentos interessados, por meio da apresentação de inventários periódicos e monitoramento da implantação das iniciativas. O plano indica que deverá ser criado indicador de efetividade para avaliar se os objetivos propostos estão sendo cumpridos.

Como exemplo de indicadores propostos no Plano Setorial da Mineração (BRASIL, 2012d, p. 68), citamos o programa de uso de novas tecnologias de mineração. Referido programa abarca três iniciativas: (i) o uso de auxílio elétrico a caminhões; (ii) uso de correias transportadoras e britagem na mina e (iii) uso de veículos híbridos.

Para a primeira iniciativa, o plano propõe três indicadores: (i) número de quilômetros de auxílio elétrico instalado; (ii) número de minas utilizando auxílio elétrico e (iii) produção sujeita ao uso de auxílio elétrico. No que tange à segunda iniciativa, o indicador proposto é o número de minas utilizando correias transportadoras e britagem na mina. Por fim, para a 
terceira iniciativa, tem-se como indicador o percentual de caminhões híbridos da frota da mina.

(D) Proposta de instrumentos de regulação e incentivo para implementação do respectivo Plano Setorial

O Plano Setorial da Mineração elenca as formas de financiamento que poderão ser utilizadas, durante os anos de 2011 e 2020, para atingir os objetivos traçados. São arroladas fontes orçamentárias previstas na Lei Orçamentária Anual, linhas específicas de crédito do Banco Nacional de Desenvolvimento Social ("BNDES"), investimentos privados, linhas de crédito voltadas a projetos de redução de emissões de carbono e utilização de recursos do Fundo Clima ${ }^{99}$.

Adicionalmente, para cada barreira identificada à implementação dos programas é proposta medida para sua superação. Dentre as medidas, algumas delas são de caráter regulatório como fomento à indústria de produção de biocombustível de palma, legislação para incentivar a produção e o mercado regular de biocombustíveis a preços competitivos, medidas governamentais de incentivo positivo à renovação da frota, entre outras.

(E) Estudos setoriais de competitividade com estimativa de custos e impactos.

O Plano Setorial da Mineração não aborda diretamente a questão dos impactos da adoção das iniciativas de mitigação de emissões para a competitividade do setor. A comparação do setor nacional em relação à indústria mineral estrangeira é citada no que diz respeito aos índices de emissões específicos por minério.

\footnotetext{
${ }^{99}$ Mencionado como um dos instrumentos da PNMC, o Fundo Clima foi criado pela Lei Federal ${ }^{\circ} 12.114$, de 09 de dezembro de 2009 e regulamentado pelo Decreto Federal $n^{\circ} 7.343$, de 23 de outubro de 2010.
} 
Em especial, o minério de ferro apresenta emissão muito menor de GEE por tonelada do produto, se comparado com seus concorrentes internacionais, principalmente devido à matriz energética limpa brasileira. Em estudo de caso apresentado no plano, enquanto no Brasil o índice é de 3,09 $\mathrm{kg} \mathrm{CO}_{2} \mathrm{eq} / \mathrm{t}$, a primeira empresa estrangeira analisada possui índice de $6,01 \mathrm{~kg} \mathrm{CO} 2 \mathrm{eq} / \mathrm{t}$ e a segunda de $9,37 \mathrm{~kg} \mathrm{CO} 2 \mathrm{eq} / \mathrm{t}$.

Os custos da adoção de algumas medidas, por sua vez, são tratados como potenciais barreiras à adoção de tais iniciativas. Nesse contexto, apresenta-se o preço pouco competitivo do biocombustível em relação ao biodiesel e o alto investimento em equipamentos para a adoção de novas formas de produção. As medidas de mitigação dessas barreiras são tratadas no item anterior.

\subsubsection{Plano ABC}

O Plano ABC foi elaborado sob a coordenação da Casa Civil da República, Ministério da Agricultura, Pecuária e Abastecimento e Ministério do Desenvolvimento Agrário. A versão final publicada do Plano ABC data de 13 de janeiro de 2012.

As principais fontes de emissões de GEE na atividade agropecuária são a fermentação entérica dos ruminantes, tratamento de dejetos de animais, cultivo de arroz em áreas alagadas, queima de resíduos agrícolas, utilização de fertilizantes nitrogenados e conversão de florestas nativas para uso alternativo do solo. A projeção das emissões de GEE por essas ações em 2020 é de 730 milhões de toneladas de $\mathrm{CO}_{2} \mathrm{eq}$, cerca de $22,5 \%$ das emissões totais nacionais para esse ano, conforme publicado no Decreto Federal nº 7.390/2010.

(A) meta de redução de emissões em 2020, expressa em percentuais das projeções previstas para este ano (incluindo metas gradativas com intervalo máximo de três anos);

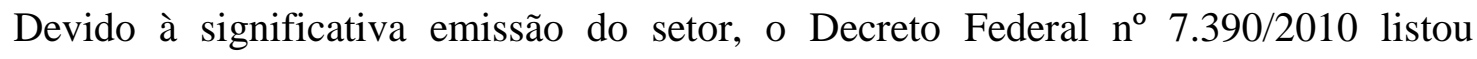
compromissos do setor para que o país possa alcançar a redução de emissões almejada pela 
PNMC, sendo elas: (i) recuperação de 15 milhões de hectares de pastagens degradadas; (ii) ampliação da adoção do sistema de integração lavoura-pecuária-floresta em 4 milhões de hectares; (iii) expansão da prática de plantio direto na palha em 8 milhões de hectares; (iv) expansão da adoção da fixação biológica de nitrogênio em 5,5 milhões de hectares de áreas de cultivo, em substituição ao uso de fertilizantes nitrogenados; (v) expansão do plantio de florestas em 3 milhões de hectares e (vi) ampliação do uso de tecnologias para tratamento de 4,4 milhões de $\mathrm{m}^{3}$ de dejetos de animais.

Tabela 7 - Processo Tecnológico, compromisso nacional relativo (aumento da área de adoção ou uso) e potencial de mitigação por redução de emissão de GEE (milhões de $\mathrm{Mg} \mathrm{CO}_{2} \mathrm{eq}$ ).

\begin{tabular}{|c|c|c|}
\hline Processo Tecnológico & $\begin{array}{l}\text { Compromisso (aumento de } \\
\text { área/uso) }\end{array}$ & $\begin{array}{l}\text { Potencial de Mitigação } \\
\left(\text { milhões } \mathrm{Mg} \mathrm{CO}_{2} \mathrm{eq}\right)\end{array}$ \\
\hline $\begin{array}{lll}\text { Recuperação } & \text { de } & \text { Pastagens } \\
\text { Degradadas } & & \end{array}$ & 15,0 milhões há & 83 a 104 \\
\hline Integração Lavoura-Pecuária-Floresta & 4,0 milhões há & 18 a 22 \\
\hline Sistema de Plantio Direto & 8,0 milhões há & 16 a 20 \\
\hline Fixação Biológica de Nitrogênio & 5,5 milhões há & 10 \\
\hline Florestas Plantadas & 3,0 milhões há & - \\
\hline Tratamento de dejetos Animais & 4,4 milhões há & 6,9 \\
\hline Total & - & 133,9 a 162,9 \\
\hline
\end{tabular}

Fonte: (BRASIL, 2012e)

Relevante notar que cada ação de mitigação traduz-se na aplicação da melhor tecnologia disponível para redução de emissões, embora esse critério não seja utilizado para diferenciar as atividades econômicas abarcadas pelo Plano ABC.

A evolução do Plano ABC poderia se dar no sentido de classificar as fontes emissoras individuais abarcadas pelo setor (por tipo de plantio ou criação, por exemplo) sendo estimado o potencial para reduzir emissões de cada qual, com vista ao estabelecimento de metas gradativas propriamente ditas. 
ações a serem implementadas;

Com base nas ações listadas no Decreto Federal n 7.390/2010, o Plano ABC detalha sete programas, que contém diversas ações para sua implementação: (i) Recuperação de Pastagens degradadas; (ii) Integração Lavoura-Pecuária-Floresta ("iLPF”) e Sistemas Agroflorestais ("SAFs"); (iii) Sistema de Plantio Direto (“SPD”); (iv) Fixação Biológica do Nitrogênio ("FBN"); (v) Florestas Plantadas; (vi) Tratamento de dejetos animais; (vii) Adaptação às mudanças climáticas.

No Plano ABC, são ainda detalhadas ações transversais, que são comuns a todos os programas, como campanha publicitária, regularização ambiental de propriedades e criação ou adequação de incentivos fiscais.

(C) definição de indicadores para o monitoramento e avaliação de sua efetividade;

O Plano ABC prevê a instituição de Comissão Executiva Nacional do Plano ABC, vinculada ao CIM e ao seu Grupo Executivo (GEx), que será responsável por monitorar as ações propostas no plano e avaliar a efetividade de sua implementação. É prevista, ainda, a instituição de Grupos Gestores Estaduais que farão a coordenação e a articulação do Plano ABC nos Estados.

Tais órgãos responsáveis pelo monitoramento deverão contar com metodologia para mensuração e contabilização periódica das reduções de GEE, garantidas integridade e transparência dos dados coletados, com possibilidade de verificação internacional. Segundo o plano, o recebimento e o processamento dessas informações serão realizados por um "Laboratório Virtual Multinstitucional de Mudanças Climáticas e Agricultura”, que será instituído por parceria entre a Empresa Brasileira de Pesquisas Agropecuárias ("Embrapa”) e a Rede Brasileira de Pesquisas sobre Mudanças Climáticas Globais ("Rede Clima”), esta com sede no Instituto Nacional de Pesquisas Espaciais (“INPE”). 
O Plano ABC aponta indicadores dos resultados de cada um de seus programas, como por exemplo, a área em hectares de pastagem recuperada para o programa de Recuperação de Pastagens Degradadas e o número de doses de inoculantes comercializadas para o programa de Fixação Biológica de Nitrogênio.

(D) proposta de instrumentos de regulação e incentivo para implementação do respectivo Plano Setorial

O Plano ABC determina a coordenação de seus programas com políticas públicas já em vigência que contribuirão com o alcance de seus objetivos, como o Programa Mais Ambiente, instituído pelo Decreto Federal n 7.029/2009, voltado à regularização ambiental da propriedade rural; o Programa Operação Arco Verde, coordenado pelo Ministério do Meio Ambiente e pela Casa Civil da Presidência da República, que trata de promover modelos produtivos sustentáveis nos municípios considerados como "prioritários para o controle e redução de desmatamento na Amazônia Legal” (BRASIL, 2012e, p. 22); Programa Terra Legal Amazônia, desenvolvido pelo Ministério do Desenvolvimento Agrário para a regularização fundiária naquela região; Programa Territórios da Cidadania, do Governo Federal, para promover o desenvolvimento econômico e "universalizar programas básicos de cidadania" (BRASIL, 2012e, p. 23); entre outros instrumentos de regulação previstos no Plano ABC.

O Plano $\mathrm{ABC}$ estima que para o alcance de seus objetivos será necessário o investimento de R $\$ 197$ bilhões, no período compreendido entre 2011 e 2020. A origem desses recursos serão as fontes orçamentárias ou linhas de crédito agrícola.

No âmbito dos incentivos para implementação do Plano ABC, estão previstas as ações transversais de elaboração de Estudo sobre novos incentivos econômicos e Proposta de adequação ou criação de mecanismos de incentivos fiscais. 
(E) estudos setoriais de competitividade com estimativa de custos e impactos.

O Plano ABC não aborda especificamente o tema do impacto à competitividade do setor agropecuário gerado pela implementação de seus programas. Prevê, apenas, como uma de suas ações transversais, elaboração de estudo para identificar barreiras e oportunidades de mercado no âmbito da redução de emissões de GEE no setor.

\subsection{Sistematização das considerações sobre os Planos Setoriais}

A análise dos Planos Setoriais nos conduz a três ordens de considerações ${ }^{100}$, sistematizadas na tabela abaixo e a seguir expostas.

Tabela 8. Aplicação de critérios pesquisados nos Planos Setoriais.

\begin{tabular}{|l|c|c|c|c|c|c||}
\hline & PDE & Indústria & Saúde & Transporte & Mineração & ABC \\
\hline $\begin{array}{l}\text { Potencial } \\
\text { para reduzir } \\
\text { emissões }\end{array}$ & - & + & $\begin{array}{c}\text { Não } \\
\text { aplicável. }\end{array}$ & - & + & + \\
\hline $\begin{array}{l}\text { Reduções } \\
\text { antecipadas } \\
\text { de emissões }\end{array}$ & - & - & $\begin{array}{c}\text { Não } \\
\text { aplicável. }\end{array}$ & - & - & - \\
\hline $\begin{array}{l}\text { Exposição ao } \\
\text { risco de fuga } \\
\text { de carbono }\end{array}$ & - & + & $\begin{array}{c}\text { Não } \\
\text { aplicável. }\end{array}$ & - & - & - \\
\hline
\end{tabular}

Fonte: elaborada pela autora.

Os Planos Setoriais publicados até o momento, em suas versões preliminares e finais, estão em diferentes níveis de amadurecimento, a depender do conhecimento agregado em torno das peculiaridades dos subsetores que abarcam e das respectivas emissões associadas.

É possível até mesmo dizer que a maioria deles consiste, na realidade, em roteiro para a elaboração de Planos Setoriais propriamente ditos, no formato determinado pela PNMC e regulamentação posterior. Ainda faltam-lhes informações cruciais e instrumentos que os tornem executáveis para o fim a que servem: direcionar o Brasil a uma economia de baixo consumo de carbono, para a consecução do compromisso nacional voluntário de redução de emissões de GEE.

\footnotetext{
${ }^{100}$ Não nos debruçaremos sobre o Plano Setorial da Saúde, vez que suas ações são voltadas para a adaptação às mudanças climáticas e ele não traz ações de mitigação, foco desta dissertação.
} 
Vimos que o Plano Setorial da Indústria, por exemplo, prevê implantação gradual de um sistema de medição, relato e verificação das emissões de GEE da atividade industrial. Somente a partir de um melhor conhecimento das atividades econômicas por ele compreendidas, será possível traçar plano de ação contendo medidas e instrumentos de incentivo à redução de emissões por cada qual, assim como indicadores para seu monitoramento e revisão periódica. O próprio plano admite que a inexistência de instrumentos de mensuração precisos para orientar as políticas nacionais é obstáculo para o alcance de sua "meta de referência".

É possível também observar a diferente abordagem dos Planos Setoriais de acordo com a natureza das atividades econômicas por eles abarcadas: se reguladas pelo Poder Público ou se sujeitas à livre-iniciativa, ou mesmo, se a redução de emissões depende de forte investimento público ou estaria atrelada a ações do setor privado.

O setor elétrico, por exemplo, é rigorosamente regulado pelo Poder Público, que detém o controle da produção de energia por meio do planejamento da oferta, mediante a realização de leilões de energia. A disponibilização de energia de baixa emissão de GEE depende de decisão estatal, que será determinante para sua geração pela iniciativa privada. Nesse sentido, observa-se que a Agência Nacional de Energia Elétrica ("ANEEL”) tem realizado recentemente leilões voltados exclusivamente para projetos de energia resultante de baixa emissão de $\mathrm{CO}_{2}{ }^{101}$. O PDE, portanto, é expressão de políticas governamentais, as quais deverão ser observadas pelo setor privado.

101 Como o Leilão 01/2012, cujo objeto foi a contratação de energia elétrica proveniente de novos empreendimentos de geração, a partir de fonte hidrelétrica, eólica e termelétrica (biomassa ou a gás natural, em ciclo combinado), com início de suprimento a partir de $1^{\circ}$ de abril de 2015. Veja-se, ainda, o Leilão 07/2011, para contratação de energia proveniente de novos empreendimentos de geração, a partir de fonte hidrelétrica, eólica e termelétrica (biomassa ou a gás natural em ciclo combinado), no Ambiente de Contratação Regulada (ACR), com início de suprimento em $1^{\circ}$ de janeiro de 2016. Dados disponíveis em <http://www.aneel.gov.br/area.cfm?id_area=53>. Acesso em 28 de outubro de 2012. 
As alterações no setor de transportes para a redução de emissões de GEE também são vinculadas a investimentos públicos, ou recursos privados viabilizados por concessões públicas, pelo que dependem de medidas a serem adotadas pelos entes públicos. Poucas ações de mitigação poderão ser tomadas exclusivamente pelo setor privado, como por exemplo, a aquisição de veículos de passeio flex e o abastecimento efetivo com biocombustível. Contudo, mesmo nessa hipótese, o Estado tem papel decisivo na elaboração de regulação voltada à manutenção da competitividade de combustíveis menos intensivos em carbono em relação àqueles de origem fóssil. Neste contexto, o Plano Setorial do Transporte também depende fortemente da atuação estatal.

O Plano da Indústria e da Mineração, de outro lado, sustenta-se prioritariamente sobre ações do setor privado. Determinada a direção pelo Estado, as ações de mitigação deverão ser suportadas pelo setor produtivo, repassadas, quando possível, para os consumidores. Por óbvio que, mesmo no caso dessas atividades sujeitas à livre-iniciativa, submetidas às regras de proteção ao meio ambiente, direito de uso do solo e subsolo, instrumentos de incentivo estatal são bem-vindos para estimular a adoção de ações de mitigação. Contudo, a diferença com relação à energia elétrica e ao setor de transportes é o menor controle estatal sobre os processos produtivos passíveis de gerar GEE.

Com relação ao Plano $\mathrm{ABC}$, observa-se um misto de dependência de políticas governamentais, voltadas aos pequenos produtores, e direcionamento dos grandes agricultores para práticas mais sustentáveis. Contudo, tendo em vista que a maior parte das emissões do setor decorre da mudança de uso da terra, lê-se, o crescente desmatamento da Amazônia, o sucesso dos planos de redução de emissões depende da ação de políticas governamentais de desestímulo ao desmatamento e fiscalização por parte dos órgãos ambientais competentes.

Constata-se que para aqueles setores em que o engajamento do setor privado é decisivo para o alcance dos resultados dos Planos Setoriais, há um maior cuidado com relação à diferenciação dos impactos gerados por cada atividade econômica ao clima como critério para o estabelecimento de ações de mitigação e metas de redução. Este fato pode ser explicado pela maior participação na elaboração dos Planos Setoriais do próprio setor produtivo a ser por eles impactado. Observou-se que as associações do setor privado, como a CNI e o IBRAM, estiveram atentas e interessadas na divisão equânime do ônus da adoção de medidas de 
mitigação entre os agentes econômicos, resguardando aquelas atividades econômicas mais eficientes que já alcançaram o menor nível possível de liberação de emissões de GEE.

No que tange, mais especificamente, à hipótese de nossa pesquisa, conclui-se que alguns dos Planos Setoriais buscam diferenciar as atividades econômicas por eles tratadas conforme suas emissões de GEE.

Dois dos Planos Setoriais analisados reúnem propostas de ações para redução de emissões de GEE, as quais, caso executadas, levariam ao alcance de certa quantidade de desvio de emissão do cenário tendencial ao cenário proposto para 2020.

Nesse sentido, o PDE e o Plano Setorial do Transporte valem-se de fatores circunstanciais para o cálculo das reduções a serem alcançadas, não sendo estabelecidas metas de acordo com a análise das emissões de cada atividade econômica e dos seus impactos ao clima. Em suma, foram simplesmente coletadas oportunidades para a redução de emissões promovidas por políticas em curso, comparadas ao cenário tendencial de inércia do Poder Público.

Com relação aos Planos Setoriais da Mineração e da Indústria, os quais se propõem a analisar as emissões das atividades econômicas e diferenciá-las conforme seus impactos ao clima, identifica-se a adoção de ao menos dois dos três critérios identificados em nossa pesquisa: a análise do potencial de cada atividade econômica para reduzir emissões e a avaliação da exposição do setor à fuga de carbono.

Embora o Plano da Indústria ainda se encontre em momento anterior à fixação de critérios para estabelecimento de meta propriamente dita de redução de emissões para a indústria de transformação, reconhece a necessidade de diferentes abordagens às atividades econômicas por ele abrangidas e prevê o estabelecimento de metas subsetoriais, com base no gás emitido, setor ou empresa.

O Plano Setorial da Indústria trata como setores as atividades de produção de (i) alumínio; (ii) cal; (iii) cimento; (iv) ferro-gusa e aço; (v) papel e celulose; (vi) química; e (vii) vidro, responsáveis por $90 \%$ das emissões da indústria. Como visto, essas atividades deverão, 
prioritariamente, contabilizar emissões, assumir compromissos setoriais e serem contempladas por "instrumentos customizados de fomento à eficiência de emissões" (BRASIL, 2012b, p. 23).

Para esses setores, o Plano Setorial da Indústria propõe que sejam elaboradas ações para redução de emissões por unidade de produto com a adoção de tecnologias menos intensivas em carbono, como a substituição de combustíveis e eficiência energética. Com isso, busca-se que a produção nacional seja mais eficiente em termos de emissões de GEE em comparação com índices globais.

Nesta concepção incorpora-se o critério do potencial da atividade para reduzir emissões na fixação de metas setoriais, que poderá ser viabilizada pela utilização de benchmarks para cada setor. Nessa linha prevê a realização de "estudos de linha de base e cenários tendenciais de emissões, levantamento de tecnologias de baixo carbono e oportunidades de mitigação nas cadeias produtivas dos setores considerados" (BRASIL, 2012b, p. 29).

Por fim, como vimos no item anterior, o Plano Setorial da Indústria também expôs a preocupação com a fuga de carbono, que ocorreria com a substituição do produto brasileiro por produtos importados, pela perda de sua competitividade com relação a seus concorrentes. Portanto, esse segundo critério para fixação de metas setoriais deverá ser levado em conta nos próximos anos no que tange à indústria de transformação.

O Plano Setorial da Mineração é o mais avançado com relação à apresentação de diagnóstico do setor, com relação a suas emissões e à propositura de ações de mitigação. Também se diferencia dos demais Planos Setoriais pela apresentação de estudo dos cenários de adesão das fontes emissoras às ações propostas, o que torna o cálculo das reduções de emissões no setor bastante transparente e realista.

No Plano Setorial da Mineração, o critério do potencial da atividade para reduzir emissões para a elaboração das ações foi totalmente efetivado, por meio da construção de índices de emissões de GEE por minério, previsão da produção para 2020 e consequentes emissões futuras. Benchmarks nacionais e internacionais foram utilizados para testar os índices de emissão, de forma a verificar a sua correspondência com a prática. 
O critério da fuga de carbono está, por sua vez, por trás da ideia exposta no Plano Setorial da Mineração com relação à inferioridade dos índices de emissões do setor brasileiro em comparação com os concorrentes internacionais. Contudo, este critério não é aplicado no plano como fator para a fixação de metas de redução, como aparece no Plano Indústria.

Por fim, vimos que o Plano ABC chega a identificar a aplicação da melhor tecnologia disponível para redução de emissões no setor, embora esse critério não seja utilizado para diferenciar as atividades econômicas abarcadas pelo plano. É possível que a evolução do Plano ABC compreenda a classificação das fontes emissoras individuais (por tipo de plantio ou criação, por exemplo), sendo futuramente estimado o potencial para reduzir emissões de cada qual, visando o estabelecimento de metas gradativas propriamente ditas.

O critério da antecipação das reduções de emissões com relação ao estabelecimento de políticas regulatórias não está presente de forma expressa nos Planos Setoriais analisados. Visto que esta questão se dá no plano das fontes individuais, parece-nos que deve vir à tona quando da efetiva imposição de metas de redução de emissões a cada uma delas, e não da forma agregada como se tem tratado os setores até o momento.

No momento apropriado, cada fonte emissora individual poderá apor argumentos lastreados em seu comportamento particular ante a obrigação de reduzir emissões. Aquelas fontes individuais que inventariaram suas emissões e adotaram ações de mitigação de emissões mensuráveis e verificáveis (por meio, por exemplo, de Projetos de MDL) poderão argumentar diferenciação em seu tratamento considerando-se a redução antecipada de emissões em benefício do clima do planeta. 


\section{CONSIDERAÇÕES FINAIS}

No primeiro capítulo desta dissertação vimos que a PNMC instituiu compromisso nacional voluntário para adoção de ações visando evitar entre 36,1\% e 38,9\% das emissões de GEE brasileiras projetadas para 2020.

O segundo capítulo tratou da abordagem setorial das ações a serem adotadas para a efetivação do compromisso nacional voluntário. A PNMC determinou que Planos Setoriais fossem elaborados de forma a consolidar uma "economia de baixo consumo de carbono" para as seguintes atividades econômicas: (i) geração e distribuição de energia elétrica; (ii) transporte público urbano e sistemas modais de transporte interestadual de cargas e passageiros; (iii) indústria de transformação e de bens de consumo duráveis; (iv) indústrias químicas fina e de base; (v) indústria de papel e celulose; (vi) mineração; (vii) indústria da construção civil; (viii) serviços de saúde; e (ix) agropecuária.

Vimos, ainda, que os Planos Setoriais devem conter metas gradativas de redução de emissões antrópicas de forma que sejam "quantificáveis e verificáveis, considerando as especificidades de cada setor". Essas metas devem ser alocadas de acordo com as "responsabilidades individuais quanto à origem das fontes emissoras e dos efeitos ocasionados sobre o clima”.

Verificamos, em seguida, que o tratamento das metas de redução de emissões, levandose em conta as especificidades de cada setor e as responsabilidades quanto à origem das fontes emissoras e dos respectivos efeitos sobre o clima, está amparado em nossa Constituição Federal.

Com efeito, a ordem econômica constitucional compreende a defesa do meio ambiente como um de seus princípios, podendo essa diretriz ser concretizada pelo tratamento diferenciado das atividades econômicas conforme o impacto dos produtos e serviços e de seus processos de elaboração e prestação. Ao final do segundo capítulo, propusemos sintetizar essa ideia na proteção do clima mediante o tratamento diferenciado das atividades econômicas conforme suas emissões. 
A hipótese da presente pesquisa de que a alocação do ônus das ações de mitigação das mudanças climáticas entre as atividades econômicas deve considerar as respectivas emissões para efetivar os ditames constitucionais e a PNMC foi confirmada. Passou-se, então, à busca de respostas para as seguintes questões propostas: identificar os critérios revelados pela doutrina e pelas experiências internacionais que podem servir para a efetivação das diretrizes da PNMC e da Constituição Federal. Identificados esses critérios, o objetivo foi o de verificar se os Planos Setoriais de Mitigação e de Adaptação às Mudanças Climáticas ("Planos Setoriais”), publicados em suas versões preliminares e finais até a conclusão desta dissertação, os adotam.

No terceiro capítulo, foram abordados critérios utilizados pelos mecanismos de mercado de emissões já implantados na União Europeia e em fase de implantação na Califórnia para a fixação de limite agregado de emissões e alocação de metas de redução de emissões entre as atividades econômicas de acordo com as suas respectivas responsabilidades quanto à origem das emissões e os efeitos ocasionados ao clima.

Sob a perspectiva normativa brasileira, em que a PNMC aponta primordialmente para a adoção de mecanismo de comando-e-controle para o alcance do compromisso nacional voluntário, foram identificados nas fontes de pesquisa os seguintes critérios para a diferenciação das atividades econômicas conforme suas emissões: (i) potencial da atividade para reduzir emissões; (ii) adoção antecipada de ações voltadas à redução de emissões pelas atividades econômicas em relação ao estabelecimento de políticas regulatórias e (iii) exposição do setor à fuga de carbono.

No quarto capítulo, concluiu-se que os Planos Setoriais estão em estágios diferenciados de maturação, segundo o nível de conhecimento sobre as atividades econômicas que compreendem e as emissões de GEE a elas associadas.

Da análise de cada plano, foi possível observar que os Planos da Indústria, da Mineração e ABC, que mais afetam a iniciativa privada, adotam, ainda que de forma incipiente, os critérios de fixação de metas identificados na doutrina e experiências internacionais. Esses planos, portanto, estão alinhados com os ditames da PNMA e da Constituição Federal, na medida em que propugnam, em maior ou menor grau, pela proteção 
do clima mediante o tratamento diferenciado das atividades econômicas conforme suas emissões.

Os Planos Setoriais do Transporte e o PDE valem-se de fatores circunstanciais, como a existência de políticas convergentes já em curso para o cálculo das reduções a serem alcançadas, não sendo estabelecidas metas de acordo com a análise das emissões de cada atividade econômica e dos seus impactos ao clima. Tais planos não adotam quaisquer critérios de diferenciação das atividades econômicas segundo suas emissões para fixação de metas.

Por fim, verifica-se que todos os Planos Setoriais merecem acompanhamento de sua evolução em direção à consolidação de uma economia de baixo consumo de carbono, para o cumprimento da legislação ambiental vigente. O tema requer o desenvolvimento de linhas de pesquisa que proponham parâmetros técnicos para a viabilização dos critérios jurídicos identificados nesta dissertação como a construção de benchmarks relacionados à emissão de GEE para cada atividade econômica. 


\section{BIBLIOGRAFIA}

ABRANCHES, Sérgio. Copenhague: antes e depois. Rio de Janeiro: Civilização Brasileira, 2010.

Aragẽo, Maria Alexandra de Sousa. O Princípio do Poluidor Pagador: pedra angular da política comunitária do ambiente. Coimbra: Coimbra Editora, 1997.

BIRnFeld, Carlos André Huning; BIRnfeld, Liane Francisca Huning. O Princípio do Tratamento Tributário Ambientalmente Diferenciado - uma interação entre o princípio da isonomia tributária e o sistema de princípios ambientais-econômicos do Estado de bem-estar ambiental brasileiro. 2011, [s/ ref.].

BrasiL. Ministério dos Transportes e Ministério das Cidades. Plano Setorial de Transporte e de Mobilidade Urbana para Mitigação da Mudança do Clima. Versão preliminar de abril de 2012, publicada para consulta pública de 15 de junho a 15 de agosto de 2012. Brasília: Ministério dos Transportes e Ministério das Cidades, 2012a.

- Ministério do Desenvolvimento, Indústria e Comércio Exterior. Plano Setorial de Mitigação da Mudança Climática para a Consolidação de uma Economia de Baixa Emissão de Carbono na Indústria da Transformação. Versão preliminar de abril de 2012, publicada para consulta pública de 15 de junho a 15 de agosto de 2012. Brasília: Ministério do Desenvolvimento, Indústria e Comércio Exterior, 2012b. 
BRASIL. Ministério da Saúde e Secretaria de Vigilância Sanitária. Plano Setorial da Saúde para Mitigação e Adaptação à Mudança do Clima. Versão preliminar de abril de 2012, publicada para consulta pública de 15 de junho a 15 de agosto de 2012. Brasília: Ministério da Saúde, 2012c.

- Casa Civil da Presidência da República e Ministério de Minas e Energia. Plano Setorial de Mitigação e de Adaptação às Mudanças Climáticas na Mineração. Versão preliminar de abril de 2012, publicada para consulta pública de 15 de junho a 15 de agosto de 2012. Brasília: Casa Civil da Presidência da República e Ministério de Minas e Energia, 2012d.

- Casa Civil da Presidência da República, Ministério da Agricultura, Pecuária e Abastecimento e Ministério do Desenvolvimento Agrário. Plano Setorial para Mitigação e Adaptação às Mudanças Climáticas para a Consolidação de uma Economia de Baixa Emissão de Carbono na Agricultura. Versão Final de 13 de janeiro de 2012. Brasília: Casa Civil da Presidência da República, Ministério da Agricultura, Pecuária e Abastecimento e Ministério do Desenvolvimento Agrário, 2012e.

. Ministério de Minas e Energia. Empresa de Pesquisa Energética. Plano Decenal de Expansão de Energia 2019. Brasília: Ministério de Minas e Energia, 2011.

. Ministério da Ciência e Tecnologia. Segunda Comunicação Nacional à ConvençãoQuadro das Nações Unidas sobre Mudança do Clima. Brasília: Ministério da Ciência e Tecnologia, 2010a.

. Ministério de Minas e Energia. Empresa de Pesquisa Energética. Plano Decenal de Expansão de Energia 2019. Brasília: Ministério de Minas e Energia, 2010b. 
BRASIL. Decreto n 7.390 , de 09 de dezembro de 2010. Regulamenta os arts. $6^{\circ}, 11$ e 12 da Lei

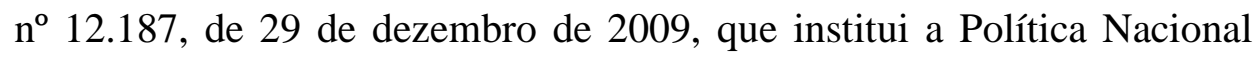
sobre Mudança do Clima - PNMC, e dá outras providências. Diário Oficial da República Federativa do Brasil, Poder Executivo, Brasília, DF, 10 de dezembro de 2010. Seção 1, p. 4, 2010c.

. Lei n ${ }^{\circ}$ 12.187, de 29 de dezembro de 2009. Institui a Política Nacional sobre Mudança do Clima - PNMC e dá outras providências. Diário Oficial [da] República Federativa do Brasil, Poder Executivo, Brasília, DF. Edição Extra, Seção 1, p. 109, 2009a.

. Portaria $n^{\circ} 3.252$, de 22 de dezembro de 2009. Aprova as diretrizes para execução e financiamento das ações de Vigilância em Saúde pela União, Estados, Distrito Federal e Municípios e dá outras providências. Ministério da Saúde. Diário Oficial da República Federativa do Brasil, Poder Executivo, Brasília, DF, 23 de dezembro de 2009. Seção 1, p. 65, 2009 b.

. Comitê Interministerial sobre Mudança do Clima. Plano Nacional sobre Mudança do Clima. Brasília: Casa Civil da Presidência da República, 2008.

Buchner, Barbara K.; CARraro; Ellerman, A. Denny. The allocation of European Allowances: Lessons, Unifying Themes and General Principles. Joint Program on the Science and Policy of Global Change. Report $n^{\circ} 140$. Cambridge, Massachusetts, october 2006.

BuChNer, Barbara K.; Ellerman, A. Denny. Over-Allocation or Abatement? A Preliminary Analysis of the EU ETS Based on the 2005-06 Emissions Data. Environ Resource Econ, Cambridge, Massachusetts, 2008, p. 267-287. 
CÁnePA, Eugenio Miguel. Economia da Poluição. In: MAY, Peter et al. (organizadores). Economia do Meio Ambiente: teoria e prática. Rio de Janeiro: Elsevier, 2003.

Cavalcante, Denise Lucena. Políticas Públicas Ambientais no Setor Automobilístico. In: SCAFF, Fernando Facury; ATHIAS, Jorge Alex (coordenadores). Direito Tributário Econômico aplicado ao meio ambiente e à mineração. São Paulo: Quartier Latin, 2009, p. 216-230.

ChIn, Dickson C.; Donnelly, Thomas M. California Adopts Cap and Trade Program for Greenhouse Gas Emissions. Disponível em: $<$ http://www.jonesday.com/california_adopts_cap_and_trade/>. Acesso em 17 de julho de 2011.

COMISSÃo EUROPEIA. Livro verde sobre a transação de direitos de emissão de gases com efeito estufa na União Europeia. Bruxelas, 2000.

. Communication from the commission on guidance to assist Member States in the implementation of the criteria listed in Annex III to Directive 2003/87/EC establishing a scheme for greenhouse gas emission allowance trading within the Community and amending Council Directive 96/61/EC, and on the circumstances under which force majeure is demonstrated, 07 de janeiro de 2004. Disponível em: <http://eurlex.europa.eu/LexUriServ/site/en/com/2003/com2003_0830en01.pdf>. Acesso em 17 de julho de 2011.

CONFEDERAÇÃO NACIONAL DA INDÚSTRIA (“CNI”). Contribuições Preliminares para Regulamentação da PNMC: Plano Indústria. Brasília, dezembro de 2011. 
CORRÊA DO LAGO, André Aranha. As negociações ambientais internacionais no âmbito das Nações Unidas e a posição brasileira. In: Mudança do Clima, Cadernos NAE/Núcleo de Assuntos Estratégicos da República, Brasília, 2005.

DERANI, Cristiane. Direito Ambiental Econômico. 2a ed. São Paulo: Max Limonad, 2001.

DiMASCIO, Nicholas. Credit where credit is due: the legal treatment of early greenhouse gas emissions reductions. Duke Law Journal, v. 56, Duke, Carolina do Norte, 2006-2007, p. 1.587.

Driesen, David M. Capping Carbon. Environmental Law, v. 40, Syracuse, NY, 2010. . Sustainable Development and Market Liberalism's Shotgun Wedding: Emissions Trading Under the Kyoto Protocol. Indiana Law Journal, v. 83, Indiana, 2008.

ECONOMic AND Allocation AdVISORy COMmitTee (“EAAC"). Allocating Emissions Allowances under a California Cap-and-Trade program. California, march, 2010.

Ellerman, A. Denny. The EU's Emissions Trading Scheme: A Prototype Global System? MIT Joint Program on the Science and Policy of Global Change, Cambridge, Massachusetts, february, 2009.

Ellerman, A. Denny; Joskow, Paul L.; Harrison JR., David. Emissions trading in the U.S: Experiences, Lessons, and Considerations for Greenhouse Gases. Pew Center on Global Climate Change, may, 2003.

Gouvello, Christophe. Estudo de Baixo Carbono para o Brasil. Brasília: Banco Mundial, 2010. 
GraU, Eros Roberto. A ordem econômica na Constituição de 1988. $7^{\text {a }}$ ed. São Paulo: Malheiros, 2002.

. Princípios da Livre-iniciativa e da Legalidade - imposição do dever de etiquetar preços. In: Revista Trimestral de Direito Público, v. 24. São Paulo: Malheiros, 1998.

. Planejamento econômico e regra jurídica. São Paulo: Revista dos Tribunais, 1978.

HARrISON JR., David et al. Using Emissions Trading to Combat Climate Change: Programs and Key Issues. Environmental Law Reporter: News and Analysis, 2008.

Keohane, Nathaniel O. Cap-and-trade is Preferable to a Carbon Tax. In: STEWART, Richard B. et al. (orgs.) Climate Finance: Regulatory and Funding Strategies for Climate Change and Global Development. 2009.

KIRK, Justin. Creating an Emissions Trading System for Greenhouse Gases: Recommendations to the California Air Resources Board. Virginia Environmental Law Journal, v. 26, 2008, p. 547.

Kossoy, Alexandre; Ambrosi, Philippe. State and Trends of Carbon Markets 2010. World Bank, 2010.

LA Rovere, Emílio Lèbre; PereIRA, André Santos. Síntese dos Diálogos Pós-Quioto. In: Mudança do Clima, Cadernos NAE/Núcleo de Assuntos Estratégicos da República, Brasília, 2005.

Lustosa, Maria Cecilia Junqueira et al. Política Ambiental. In: MAY, Peter et al. (organizadores) Economia do Meio Ambiente: teoria e prática. Rio de Janeiro: Elsevier, 2003. 
Machado, Paulo Affonso Leme. Direito Ambiental Brasileiro. $17^{\mathrm{a}}$ ed. São Paulo: Malheiros, 2009.

Mankiw, N. Gregory. Introdução à Economia. $3^{\mathrm{a}}$ ed. São Paulo: Thomson Learning, 2007.

Margulis, Sérgio; DubeuX, Carolina B. S. Economia da Mudança do Clima no Brasil: custos e oportunidades. Coordenação geral de Jacques Marcovitch. São Paulo: IBEP Gráfica, 2010.

McAllister, Lesley K. The Overallocation Problem. In Cap-And-Trade: Moving Toward Stringency. Columbia Journal of Environemntal Law, v. 34, Columbia, 2009.

. Beyond Playing "Banker": The Role of Regulatory Agency in Emissions Trading. Administrative Law Review, v. 59, San Diego, Spring 2007.

Nusdeo, Ana Maria de Oliveira. Pagamento por Serviços Ambientais: sustentabilidade e disciplina jurídica. São Paulo: Atlas, 2012.

- Desenvolvimento Sustentável do Brasil e o Protocolo de Quioto. In: Revista de Direito Ambiental. São Paulo: Revista dos Tribunais, v. 37, janeiromarço, 2005.

.O uso de instrumentos econômicos no direito ambiental brasileiro. In: Revista da Faculdade de Direito. São Paulo: Universidade de São Paulo, 2006.

NuSDEO, Fábio. Desenvolvimento e ecologia. São Paulo: Saraiva, 1975. . Curso de economia: introdução ao direito econômico. $3^{\mathrm{a}}$ ed. São Paulo: Revista dos Tribunais, 2001. 
Parlamento e Conselho Europeu. Directive 2009/29/EC of 23 April 2009 amending Directive 2003/87/EC so as to improve and extend the greenhouse gas emissions allowance trading scheme of the Community. Disponível em: $<$ http://eur-

lex.europa.eu/LexUriServ/LexUriServ.do?uri=CELEX:32009L0029:EN: NOT>. . Directive 2003/87/EC of 13 October 2003 establishing a scheme for greenhouse gas emission allowance trading within the Community and amending Council Directive 96/61/EC. Disponível em: <http://eurlex.europa.eu/LexUriServ/LexUriServ.do?uri=CELEX:32003L0087:EN: NOT>.

QUIRION, Philippe. Historic versus output-based allocation of GHG tradable allowances: a comparison. Climate Policy, v. 9, 2009, p. 575-592.

SILVA, José Afonso da. Direito ambiental constitucional. $8^{\mathrm{a}}$ ed. São Paulo: Malheiros, 2010.

SEROA DA MOtTA, Ronaldo. O uso de instrumentos econômicos na gestão ambiental. São Paulo: Abril, 2000.

SEROA DA MotTA, Ronaldo; Young, Carlos Eduardo Frickmann. Instrumentos Econômicos para a Gestão Ambiental no Brasil. Paper - Brasília: Ministério do Meio Ambiente, 1997.

StATE Of CALIFORNiA. Air Resources Board. Resolution 10-42 of december 16, 2010. 
STERn, Nicholas. Stern Review on the Economics of Climate Change: Executive Summary. 2006. Disponível em: <http://www.hmtreasury.gov.uk/d/Executive_Summary.pdf $>$. Acesso em 29 de setembro de 2012.

. Global Deal: Climate Change and the Creation of New Era of Progress and Prosperity. New York: Public Affairs, 2009.

STRECK, Charlotte. Expectations and Reality of the Clean Development Mechanism. In: STEWART, Richard B. et al. (orgs.) Climate Finance: Regulatory and Funding Strategies for Climate Change and Global Development. New York, 2009.

Tietenberg, Tom. The Tradable-Permits Approach to Protecting the Commons: Lessons For Climate Change. Oxford Review of Economic Policy, v. 19, n 3, Oxford, 2003.

TILl, Dustin. California Air Board Approves Controversial Greenhouse Gas Cap-and-Trade Rules. Novembro de 2011. Disponível em: <http://www.martenlaw.com/newsletter/20111102-calif-ghg-cap-andtrade-rules>. Acesso em 25 de setembro de 2011.

United Nations EnVironment Programmme (“UNEP”). The Use of Economic Instruments in Environmental Policy: Opportunities and Challenges. United Nations Publication, 2004.

WINTER, Gerd. The Climate is no Commodity: Taking Stock of the Emissions Trading System. Journal of Environmental Law. Oxford University Press, v. 22, $\mathrm{n}^{\circ} 1$, Oxford, 2010. 